\title{
SUMMARY DESCRIPTION \\ OF THE GEOLOGIC ENVIRONMENT \\ OF THE WILLISTON BASIN LIGNITE FIELDS, NORTH DAKOTA
}

Donald E. Trimble, compiler

U.S. Geological Survey Open-file Report 78-920

This report is preliminary and has not been edited or reviewed for conformity with U.S. Geological Survey standards and nomenclature. 
Introduction (untitled)- 1

Sources of information- 5

Physiographic description- 6

Central Lowland-_ 6

Great Plains-1- 7

Glaciated Missouri Plateau section-_-_- 7

Unglaciated Missouri Plateau section- 10

Geologic description- 14

Stratigraphy- 14

Pre-Hell Creek strata-_ 16

Hel1 Creek Formation (Upper Cretaceous)- 18

Fort Union Formation (Paleocene)- 19

Golden Valley Formation (upper Paleocene and

lower Eocene)- 21

White River Formation or Group (Oligocene)- - 22

Chadron Formation- 23

Brule Formation-_- 23

Arikaree Formation (Miocene)- 23

Glacial deposits (Pleistocene) 24

Alluvium (Pleistocene and Holocene)- 25 
Geologic description--Continued

Stratigraphy--Continued

Landslide deposits (Holocene)- 25

Structure-- 26

Williston Basin- 26

Folds- 28

Fractures- 29

Landscape geochemistry by Jon J. Connor- 31

Physical properties of the Fort Union Formation by

E. E. McGregor, and W. K. Smith- 52

Geologic hazards- 61

Slope stability of the Fort Union Formation by

W. Z. Savage-- 62

Slope stability calculations- 62

Conclusions- 67

Landslides by Roger B. Colton- 68

Surface subsidence by C. Richard Dunrud-_ 70

Coal mine fires by C. Richard Dunrud- 72

Seismic risk- 74

Economic resources- 75

Lignite by Edward J. McKay- 75

Lignite chemistry- 79 
Economic resources--Continued

Oil and gas by Charles W. Spencer-

Relation of petroleum reservoirs to tectonic features- 88

Present production-- 91

Future exploration- 94

Uranium resources by Norman M. Denson- 95

Construction materials by Robert M. Lindvall- 98

Sand and gravel- 98

Stone- 99

Pseudoquartzites- 100

Scoria-D 100

Boulders 100

Dimension stone-D- 101

Other nonmetallic mineral resources by Robert.M. Lindvall 102

Clay- 102

Salt-- 102

Sodium sulfate- 102

Sulfur- 102

References cited-D 103 


\section{Figures}

Page

Figure 1. Strippable coal deposits of North Dakota-------- 3

2. Geologic map of western North Dakota-_- 4

3. Glacial map of western North Dakota- 9

4. Preglacial Crainage in North Dakota- 11

5. Generalized cross section of the Williston Basin

in North Dakota- 15

6. Diagrammatic section through the Fort Union region-- 17

7. Structure contour map of Williston Basin, North

Dakota-_ 27

8. Lineament trends- 30

9. Regression trends in Parmelia chlorochroa for

concentrations of fluorine, selenium, strontium, and ash progressing east from the Dave Johnston powerplant- 46

10. Metal trends in sagebrush away from powerplant------ 47

11. Idealized cross section through an open pit in

the Fort Union Formation- 63

12. Potential surfaces of failure for which safety

factors were calculated-_- 64

13. Map showing oil and gas fields of North Dakota and adjacent Montana and South Dakota-_- 87

14. Map of North Dakota and adjacent areas

showing distribution of oil and gas fields------ 89 
Page

Fig. 15. Generalized stratigraphic column, North Dakota

portion of Williston basin- 93 
Tables

Page

Table 1. Probable upper limits of concentration to be expected in ordinary landscape materials of the Northern Great Plains- 36-39

2. Copper and molybdenum in sweetclover, and $\mathrm{pH}$ in spoil materials from eight coal mines in the Northern Great Plains-

3. Statistical analysis of element concentrations in ash of crested wheatgrass at Dave Johnston Mine--

4. Maximum element concentrations observed in shallow ground water from both domestic and livestock weils of the Northern Great Plains- 50

5. Results of triaxial tests- 54-58

6. Results of Poisson's Ratio tests- 59

7. Results of Brazilian Cylinder tests- 60

8. Safety factors calculated by method of slices for the five potential failure surfaces- 66

9. Estimated original lignite resources of North Dakota- 77

10. Method of recovery of lignite reserves of North Dakota, Jan. 1, 1972- 78

11. Average analysis of coal by county and bed--- 82 12 Proximate, ultimate, Btu, and sulfur analyses of 31 samples of 1ignite from western North Dakota--- $82 a$ 
13. Quantitative determinations for 12 țrace elements in 46 samples of lignite from western North Dakota-_

14. Major oxide composition, in percent, of the laboratory ash of 46 samples of lignite from western North Dakota_ 84

15. Summary of selected North Dakota oil fields_-____- 92 
SUMMARY DESCRIPTION

OF THE GEOLOGIC ENVIRONMENT

OF THE WILLISTON BASIN LIGNITE FIELDS,

NORTH DAKOTA

by

Donald E. Trimble

Lignite has been known in North Dakota since Lewis and Clark noted its presence in the journal of their traverse of the Missouri River in 1805, and it has been mined in North Dakota since 1884 (Brant, 1953, p. 57). Initially the mining activity was underground, but strip mining operations have become dominant (fig. 1) and since 1965 all lignite

Figure 1.--NEAR HERE

produced in the state has come from strip mines (Landis, 1973, p. 50). The lignite-bearing rocks of North Dakota are basin-fill deposits of Late Cretaceous and Paleocene age that occur mainly in the Williston Basin, in the western part of the state. The eastern boundary of the area discussed here (fig. 2) is, therefore, the eastern edge of outcrop

Figure 2.--NEAR HERE

of the Upper Cretaceous Hell Creek Formation in the southern third of the state and the eastern margin of the known limits of distribution of the Paleocene Tongue River Member of the Fort Union Formation north of the 47th parallel. The international and state boundaries form the northern, western, and southern limits of the discussion area, except 
for a small area of older rocks along the crestal part of the Cedar

Creek Anticline in the extreme southwest corner of the state which is excluded. 
$\operatorname{CANADA}$

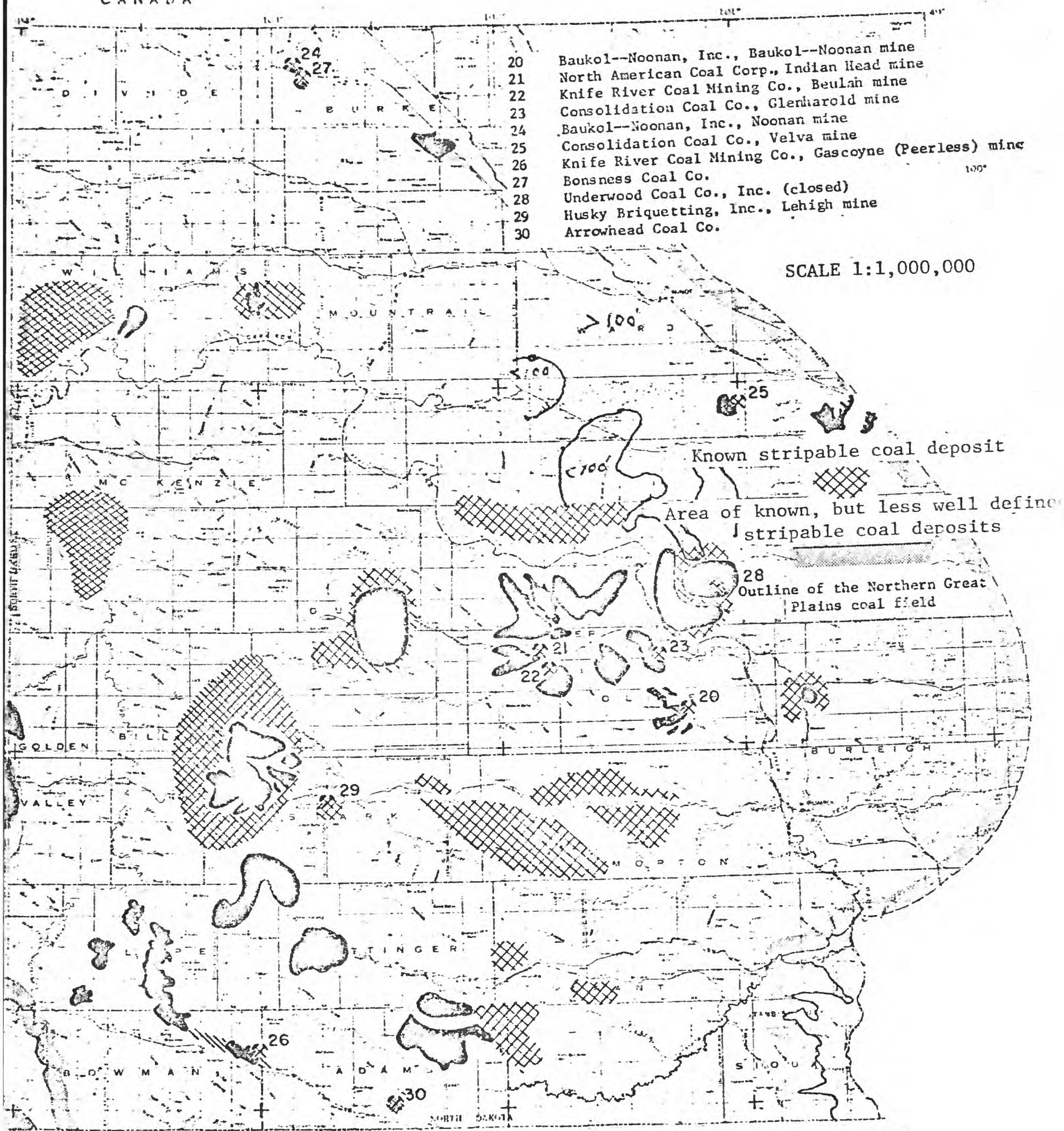

Figure 1. Stripping coal deposits of North Dakota

( From U.S. Geol. Survey Min. Field Studies Map MF-590, 1974) 


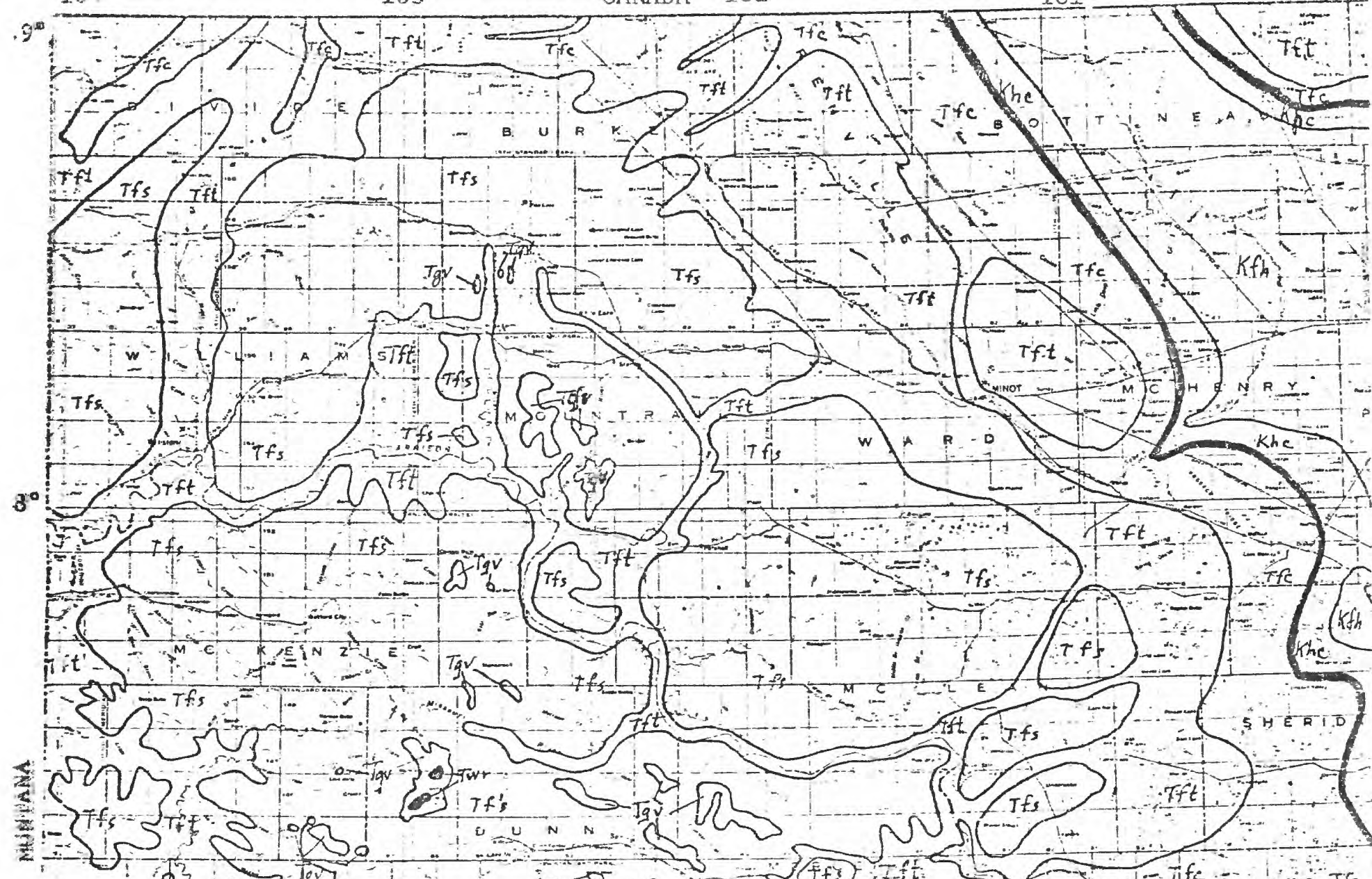

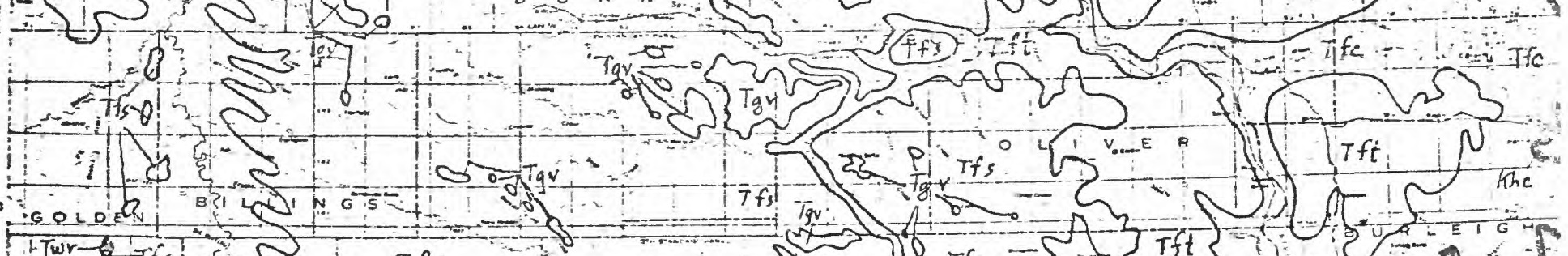

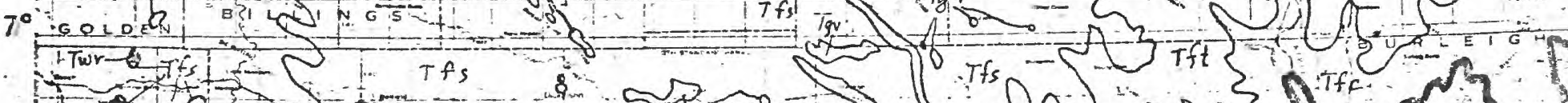
Tfort Tfs SNo $25 / S_{\text {Twr }}$. Tfs

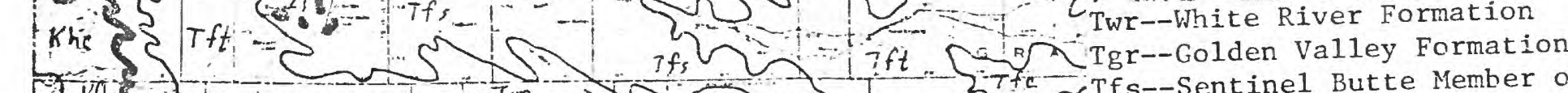
Gxifhe

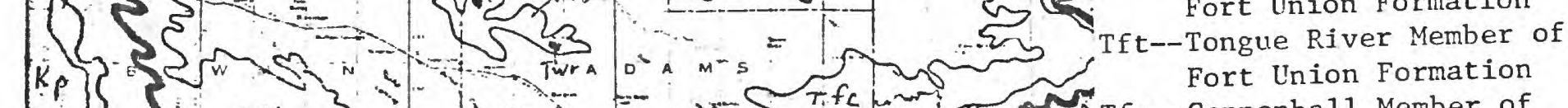

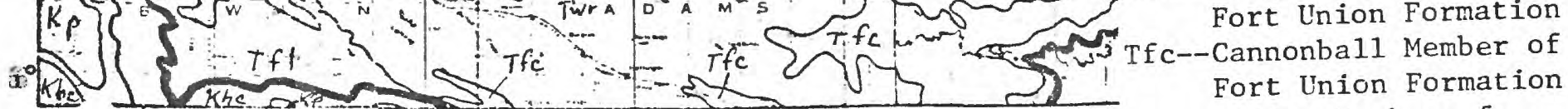
SOUTH DAKOTA

Scale: 1 inch equals. 24 miles or about $1: 1,500,000$.

Figure 2.--Geologic map of western North Dakota. Heavy line indicates base of Fort Union Formation. (Map modified from Carlson, 1969) 
This summary description of the geologic environment of the lignite fields of the Williston Basin in North Dakota is intended to provide the geologic setting for use in the preparation of Environmental Impact Statements for proposed lignite development in the region. Inasmuch as the lignite has a narrow stratigraphic range of occurrence, the generalizations provided here should have broad regional application, and should reduce the duplication of effort that otherwise would be required in the preparation of those statements.

\section{SOURCES OF INFORMATION}

The descriptive material provided here was compiled from the existing 1iterature and is current to 1976. The published sources are Iisted in the references at the end of the report. D. E. Trimble prepared the general descriptive sections on physiography, stratigraphy, and structure, but the specialized sections on resources, geologic hazards, and geochemical and geotechnical aspects have been provided by others with expertise in those fields. The many contributors are acknowledged in the sections for which they are responsible. Alphabetically listed, they are Roger B. Colton, Jon J. Connor, Norman M. Denson, C. Richard Dunrud, Robert M. Lindva11, Edward E. McGregor, Edward J. McKay, Wiliiam Z. Savage, william K. Smith, and Charles W. Spencer, all of the U.S. Geological Survey. 


\section{PHYSIOGRAPHIC DESCRIPTION}

The part of North Dakota described in this report is entirely within the Glaciated and Unglaciated Missouri Plateau Sections of the Great Plains except for an area at the northeastern margin that is part of the Central Lowland. A northeast-facing escarpment (the Missouri Escarpment), commonly 60-90 m high, marks the eastern edge of the Great Plains,

\section{Central Lowland}

In the Central Lowland east of the Missouri Escarpment, beds of the Paleocene Fort Union Formation are covered by $30-75 \mathrm{~m}$ of glacial deposits, mostly till (Lemke and others, 1965, p. 18). The easternmost part of the area within the Souris River loop, however, is covered by the deposits of a proglacial lake, Glacial Lake Souris, which formed at the margin of the receding ice front during recession of the last major advance of the ice in this area. The deposits of Glacial Lake Souris range in thickness from zero to at least $22 \mathrm{~m}$ (Lemke, 1960). Ice of the last major advance here was confined almost entirely to the Central Lowland, and overlapped onto the Coteau du Missouri only slightly to leave the record of its terminus as the Martin Moraine (Lemke and others, $1965, \mathrm{p} \cdot 24)$. 


\section{Great Flains}

Glaciated Missouri Plateau Section.--Between the Missouri River and the Central Lowland Section, a topographically high belt of hummocky, ridged terrain is pitted by kettles and other undrained depressions. Numerous sinuous meltwater channels, many of which contain elongate lakes, wind their way across the surface of this drift-covered plateau. This complex of end moraines and stagnation moraines, whose eastern margin is the northeast-facing scarp at the east edge of the Great Plains, is called the Coteau du Missouri (fig. 3). Its southwestern

Figure 3. - NEAR HERE

margin is marked by the Alamo terminal moraine (Lemke and others, 1965). Before 1950, the entire morainal complex was called the Altamont moraine. The till on the Coteau du Missouri locally is more than $30 \mathrm{~m}$ thick over a large area south and west of Minot (Andrews, 1939, Plate II).

Southwest of the Coteau du Missouri, and extending to and local1y beyond the Missouri River, is an area of older ground moraine characterized by low relief (less than $15 \mathrm{~m}$ ) and numerous shallow undrained depressions. This moraine commonly is 6-15 m thick. 
The maximum extent of glaciation in North Dakota is poorly defined, and is determined mainly by the outer limit of glacial erratic (Benson, 1953, p. 184-194). The glacial deposits between this poorly defined boundary and the Missouri River consist mainly of erratic boulders and a few ice-contact deposits (Lemke and others, 1965, p. 21). Bedrock commonly is exposed at the surface. Drainage is well integrated, and the general character of the terrain is not unlike that of the Unglaciated Missouri Plateau Section to the south.

8 


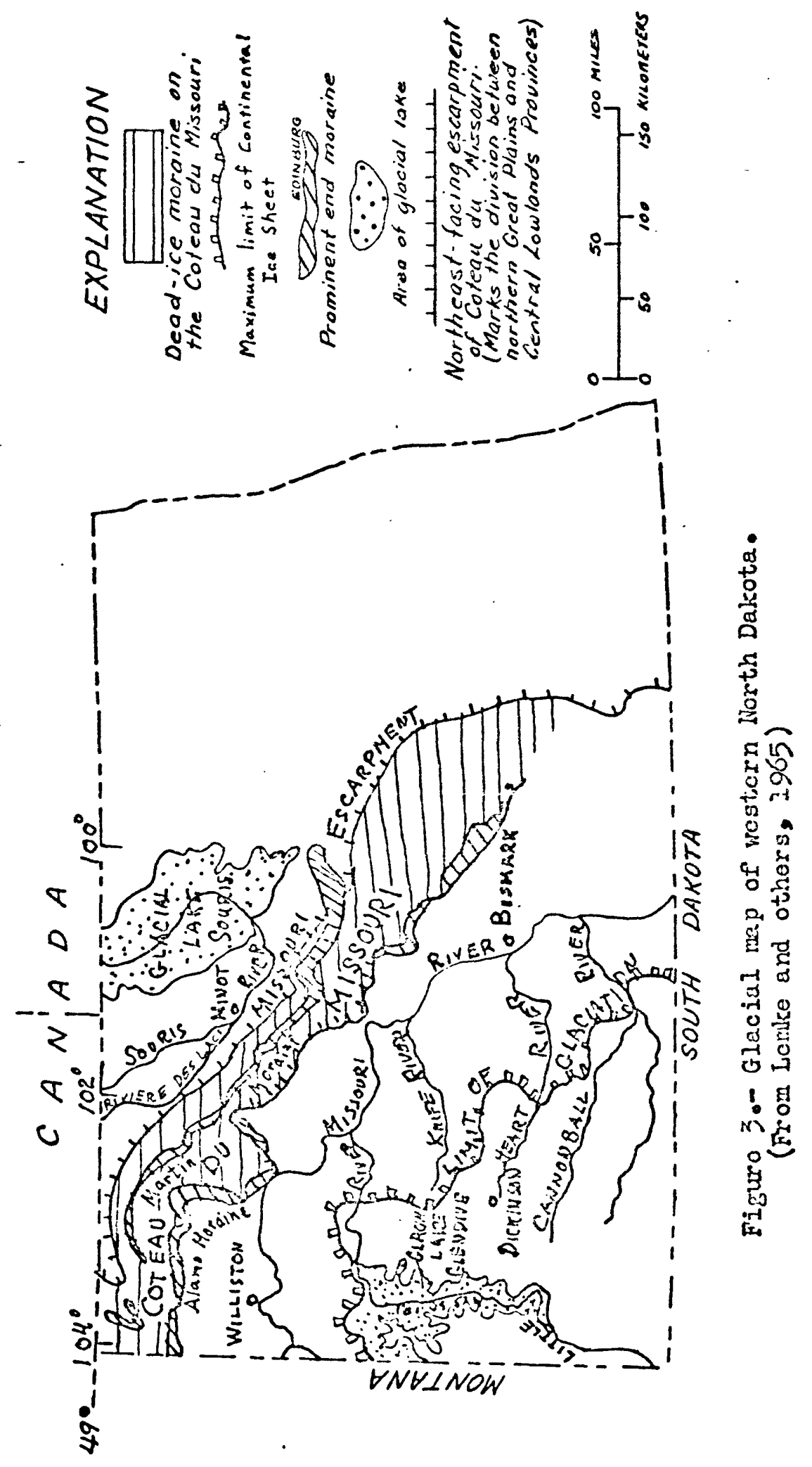


Before the onset of glaciation, the course of the Missouri River was far to the north of its present course, and the preglacial Missouri flowed northeasterly across the extreme northwest tip of North Dakota into Canada. The Yellowstone and Little Missouri Rivers flowed northward through northwestern North Dakota to join the Missouri north of the international boundary. Waters of the Knife, Heart, and Cannonbal1 Rivers, however, flowed eastward and northeastward where they merged and flowed northward into Canada. These rivers were forced to adopt new courses because of blocking and damming by the advancing ice fronts, and the present course of the Missouri River (fig. 4) is essentially an ice-marginal channel that is joined successiveiy

Figure 4. - NEAR HERE

by the Little Missouri, Knife, Heart, and Cannonball Rivers (Bluemle, 1972). The Missouri River has cut its present valley about $175 \mathrm{~m}$ below the upland surface.

Unglaciated Missouri Plateau Section.--Drainage in the area south of the maximum position of the ice front is much the same as it was before glaciation. The Little Missouri River flows northward to the former maximum position of the ice front, where it turns eastward following a former ice-marginal channel. The Knife, Heart, and Cannonball Rivers, whose headwaters are separated from the Little Missouri by a north-trending drainage divide, all flow eastward in preglacially established courses to join the glacially diverted southflowing Missouri River. 


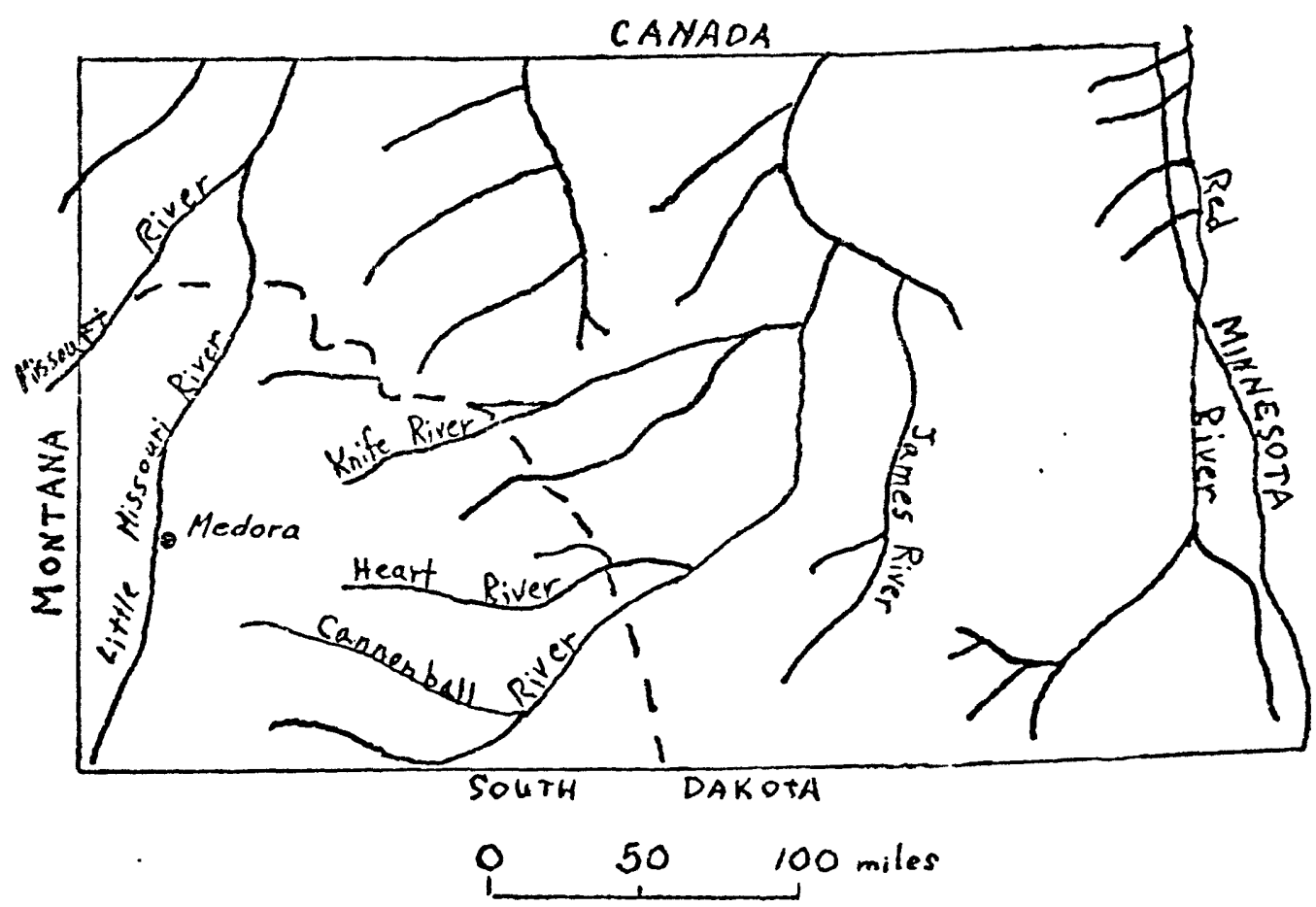

Figure 40- Preglacial drainage in North Dokota. Dashed line rejresents route of presert Misscuri River. (Hodified from Bluemle, 1972) 
The north-trending preglacial valley of the Little Missouri is nearly $50 \mathrm{~km}$ wide at Medora, and is characterized by badlands development. Its east-trending glacially diverted course is less than $15 \mathrm{~km}$ wide, and is characterized by steep valley walls and many landslides.

A proglacial lake, Glacial Lake Glendive, formed in the blocked valley of the Little Missouri River. Glacial Lake Glendive apparently was short-lived, for it left little record in the way of lacustrine deposits. Recognition of the former existence and extent of the lake is based mainly on the distribution of ice-rafted erratics and the altitudes of supposed spillways (Lemke and others, 1965, p. 18).

The rest of the unglaciated Missouri Plateau in North Dakota is a gently northeast sloping plateau of little relief except where it is surmounted by isolated buttes and mesas that are the erosional remnants of higher interstream divides, or where entrenched by the Knife, Heart, and Cannonball Rivers and their tributaries, which are incised $60-90 \mathrm{~m}$ below the general level of the plateau. The walls of these valleys commonly are steeply sloping and have smooth, rounded forms typical of long-established drainage courses.

The general upland terrain commonly is rolling prairie, but sandstone ledges and red fused rock layers (clinker) resulting from the burning of lignite are resistant beds that form benches and locally cap small mesa-like features. Softer siltstone, mudstone, and claystone layers locally have been dissected to produce badiland topography, but more commonly form smooth rounded slopes between benches. 
Mountains, buttes, and mesas in western North Dakota are of different sizes and heights, ranging from the Killdeer Mountains with a total relief of about $210 \mathrm{~m}$ (high point $1,010 \mathrm{~m}$ ) to Sentinel Butte, Flat Top Butte, Bullion Butte, Black Butte, Chalky Buttes, and many others with relief of about $150 \mathrm{~m}$, on down to lesser buttes of $60-90 \mathrm{~m}$ or less of relief. White Butte, just east of Chalky Buttes, is th:a highest point in the state with an altitude of $1,068.63 \mathrm{~m}(3,506 \mathrm{ft})$. The Missouri River to the east is at an altitude of about $488 \mathrm{~m}$ where it leaves the state, so the total relief in the entire state is only about $580 \mathrm{~m}(1,900 \mathrm{ft})$. 


\section{GEOLOGIC DESCRIPTION}

Stratigraphy

Nearly $5,180 \mathrm{~m}(17,000 \mathrm{ft})$ of mostly marine deposited sedimentary rocks representing every geologic system overlie the Precambrian crystalline basement rocks near the center of the Williston Basin, southeast of Williston, North Dakota (fig. 5).

Figure 5.--NEAR HERE 


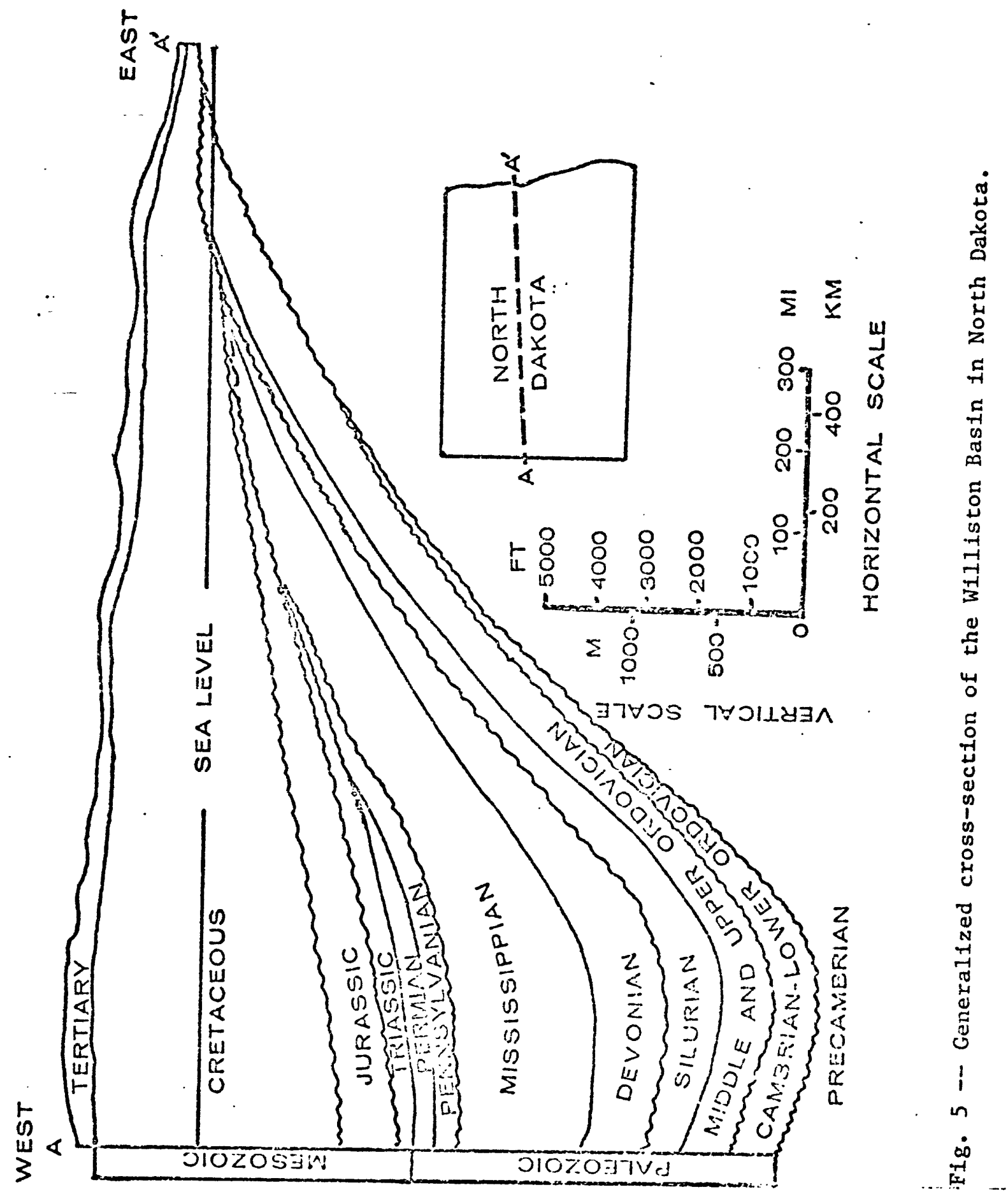


Pre-Hell Creek strata.--Sedimentary rocks of the Williston Basin (see fig. 15) were deposited in a nearly continuously subsiding structural basin (Carlson and Anderson, 1965; Car1son and Anderson, 1973a). Although the seas persisted here throughout the Paleozoic until the end of the Permian and returned in the latter part of the Early Cretaceous, the basin became isolated at various times during the Devonian and Mississippian as well as during the Permian, and great thicknesses of evaporites were deposited in the central parts of the basin. Through much if Triassic, Jurassic, and Early Cretaceous time the basin was free of seas, or contained only highly saline isolated seas where evaporites accumulated, but late in Early Cretaceous time the basin again became part of a great inland sea that persisted to near the end of the Cretaceous. More than $1,220 \mathrm{~m}(4,000 \mathrm{ft})$ of marine sediments were deposited in the Williston Basin during the existence of this Cretaceous sea. After the sea receded, the area of the Williston Basin was a coastal plain and low flood plain where three-horned dinosaurs (Tricerotops) roamed. Sediments laid down on this coastal plain by sluggish streams form the Hell Creek Formation (Fig. 6), the youngest of the pre-Tertiary rocks of the Williston Basin.

Figure 6. --NEAR HERE 


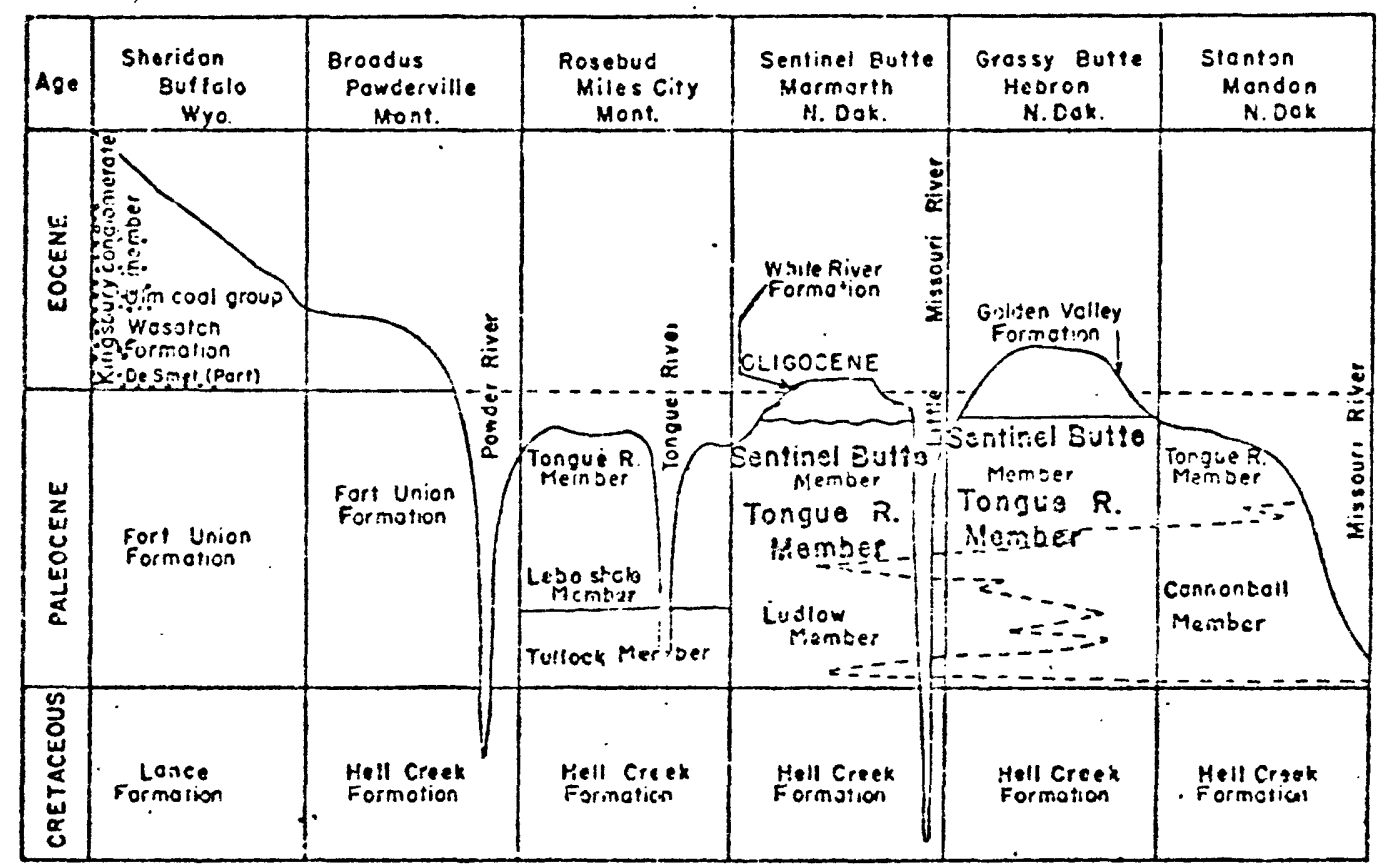

Figure 6.--Diagramatic section through the Fort Union region. Stippled parts indicate dark zones of strata of all kinds; unstippled parts are light-colored zones(Modified from Brant, 1953, p.11). 
Hell Creek Formation (Upper Cretaceous).--The Hell Creek Formation generally consists of less than $122 \mathrm{~m} \cdot(400 \mathrm{ft})$ of dark-colored carbonaceous shale and sandstone that contain some lignite seams, generally less than $0.76 \mathrm{~m}(2.5 \mathrm{ft}$ ) thick (Brant, 1953, p. 1). These thin lignite seams are impure and discontinuous (Landis, 1973). In southwestern North Dakota the Hell Creek is as much as $175 \mathrm{~m}$ (575 ft) thick (Hares, 1928, p. 47). The Hell Creek underlies the Fort Union Formation throughout the basin. 
Fort Union Formation (Paleocene).--The oldest Tertiary strata in the Williston Basin compose the Fort Union Formation. The Fort Union, which locally is as much as $610 \mathrm{~m}(2,000 \mathrm{ft}$ ) thick (Landis, 1973, p. 48), overlies the Hell Creek Formation. Fort Union Formation is the bedrock that underlies most of the area of this report.

The Fort Union Formation in the Williston Basin is composed of four members (in ascending order)--the Ludlow, Cannonball, Tongue River, and Sentinel Butte Members. All the known commercially strippable lignite reserves in North Dakota are in the Tongue River and Sentinel Butte Members of the Fort Union Formation (Smith and others, 1973, p 53). The Ludlow, like the Tongue River and Sentinel Butte Members, was deposited in a nonmarine environment and contains some lignite. It is the basal member of the Fort Union. The Ludlow occurs only in the southern part of the State, south of the latitude of Bismark. It is thickest and best-exposed in Bowman County, in the southwestern part of the State, where it reaches a maximum thickness of $76 \mathrm{~m}(250 \mathrm{ft})$ and contains an aggregate of almost $12 \mathrm{~m}(40 \mathrm{ft}$ ) of coal in one area (Brant, 1953, p. 12; Hares, 1928, p. 25-26), but it thins rapidly eastward and northward from Bowman County (Landis, 1973, p. 48). The Ludlow is equivalent to both the Tullock and Lebo Members of the Fort Union Formation of the Powder River Basin of Wyoming and Montana, but these members are not separable in the Williston Basin (Brown, 1962, p. 6). The Ludlow Member of the Fort Union Formation consists of somber shale and mudstone, light-colored sandstone, and lignite. 
The Cannonball Member of the Fort Union Formation, unlike the other members, is of marine origin. It does not contain lignite. The Cannonball intertongues with the Ludlow Member in the southwestern corner of the State, and entirely replaces it along the eastern side of the Williston Basin north of Bismark.

The Cannonball is about $9-15 \mathrm{~m}(30-50 \mathrm{ft})$ thick along the northeast side of the area near Velva, where it crops out along the Souris River valley wall (Lemke, 1953). The Cannonball consists mostly of alternating thin beds of tan to brown sandstone and sandy shale, but locally is mostly shale, some of which is dark colored.

The Tongue River Member is the most widespread bedrock unit in western North Dakota, and it underlies most of the area described here. Maximum thickness of the Tongue River Member probably is more than $335 \mathrm{~m}$ $(1,100 \mathrm{ft}$ ) (Brant, 1953, p. 12). In the Glen lillin-Dengate area, where it is about $91 \mathrm{~m}$ (300 ft) thick (Barclay, 1973; Barclay, 1974; Smith, 1973), it consists of a lower half composed of thick light- or yellowish-gray lenticular sandstone beds, thick olive and brownish-gray mudstone and subordinate claystone beds and a few carbonaceous shale and lignite beds, and an upper half composed of yellowish-gray or light olive gray sandstone and light yellowish-orange-weathering mudstone, siltstone, and clayey siltstone, a few lignite beds, and limestone pods at two or more horizons (Barclay, 1973). 
The Sentinel Butte Member of the Fort Union Formation is about 61-122 m (200-400 ft) thick. Lithologically, the Sentinel Butte is similar to the Tongue River Member, but commonly it is darker colored. It consists of alternating thick dark bentonitic mudstone and claystone and light-colored siltstone and sandstone. The basal contact in places is drawn at the base of the lowest dark bentonitic mudstone above a sequence of 1ight-colored beds of the Tongue River Member (Barclay, 1973; Royse, 1967). In other places in western North Dakota, the contact is drawn between a locally thick lignite, the HT lignite bed of the Tongue River Member, and an overlying silty sandstone that in some places ranges from several meters to more than $30 \mathrm{~m}$ (100 ft) thick (Royse, 1967, p. 527).

Golden Valley Formation (upper Paleocene and lower Eocene).-Although Brown (1962, p. 20) said "The beginning of the Eocene is marked by strata of the Golden Valley Formation containing the floating fern Salvinia preauriculata Berry," the Golden Valley now is considered to be late Paleocene and early Eocene in age (Hickey, 1969). The Golden Valley Formation conformably overlies strata of the Fort Union Formation in high buttes in western North Dakota, and in areas of considerable size between the Knife River and the Little Missouri River west of Beulah, between the Knife River and the Heart River north and west of Hebron, between the Heart and the Cannonball Rivers south of Dickinson, and in lesser areas north of the Little Missouri River but south of the Missouri River. Golden Valley Formation evidently is not present in the southwestern part of the State. South of the Cannonball River it does not occur at HT Butte or Chalky Buttes (Moore and others, 1956). 
The maximum preserved thickness of the Golden Valley Formation is $55 \mathrm{~m}$ (180 ft) (Hickey, 1969). The Golden Valley consists of a lower member of fluvially deposited kaolinitic claystone, siltstone, and sandstone that is 6-12 $\mathrm{m}(20-40 \mathrm{ft})$ thick, and an upper fluvial member of illitic and montmorillonitic fine-grained sediments. Bright yellow and orange colors, and leached and oxidized zones characterize the formation, which also contains thin lignite at its upper boundary. White River Formation or Group (0ligocene).--In most places the White River has not been divided into mappable unit: and is designated the White River Formation. It unconformably overlies the Golden Valley Formation in many buttes and erosional remnants south of the little Missouri River and north of the Cannonball River. South of the Cannonball and west of the Little Missouri, the White River Formation overlies the Sentinel Butte Member of the Fort Union Formation, In the Chalky Buttes area in Slope County (Moore and others, 1956) and in the White Butte area, Stark and Hettinger Counties (Soward, 1975a, 1975b, 1975c, and 1975d), however, the White River is of group rank and has been subdivided into the Chadron Formation and the overlying Brule Formation. The Brule caps a number of spires in the Chalky Buttes, but is not present in the White Butte area.

The White River consists of fluvial and lacustrine basin-fill sedimentary rocks, coarser grained near the base and finer grained in the upper parts. The combined thickness of the Chadron and the Brule is about $76 \mathrm{~m}$ (250 ft) (Denson and Gi11, 1965, p.9). 
The Chadron Formation consists of a basal conglomeratic sandstone that is as much as $7 \mathrm{~m}(23 \mathrm{ft})$ thick in the White Butte area, a middle sandy claystone (1-4.6 m thick), and an upper 4.6-12 m (15-40 ft) of interbedded calcareous claystone and limestone.

The Brule Formation, present only in the Chalky Buttes, the Little Badlands in Stark county, Rainy Buttes, and Black Butte (Denson and Gi11, 1965, plate 3) is siltstone, mudstone, and claystone that elsewhere forms badlands.

The Arikaree Formation (Miocene).--The Arikaree is the youngest of the Tertiary basin-fill deposits of the Williston Basin in North Dakota. The Arikaree Formation unconformably overlies upper Paleocene and lower Eocene Golden Valley Formation in the Killdeer Mountains, south of the Little Missouri River, and overlies White River Group at Chalky Buttes, Rainy Buttes, Little Badlands, and Coffin Butte south of the Cannonball River and Black Butte, north of the Cannonball (Denson and Gill, 1965, p1. 3). It consists of sandstone, limestone, shale, and conglomerate, and has a maximum thickness of about $76 \mathrm{~m}(250 \mathrm{ft}$ ) (Keefer, 1974). Its areal extent is very limited. 
Glacial deposits (P1eistocene).--The glacial deposits consist mainly of end moraine, stagnation moraine, ground moraine, and glaciofluvial and glaciolacustrine deposits. Although the maximum position of the ice front-was far to the south of the Missouri River, the glacial deposits are confined primarily to that part of the region north and east of the Missouri River. South and west of the Missouri River they consist mostly of erratic boulders and glaciofluvial deposits of limited extent.

The glaciofluviai deposits include gravel, sand, and silt of meltwater channels, kames and kame terraces, and eskers. The glaciolacustrine deposits are thin marginal or shoreline deposits of sand or fine gravel of an arm of Glacial Lake Souris and some thin finegrained lacustrine deposits along the Little Missouri River that were deposited in Glacial Lake Glendive.

The Coteau du Missouri, north of the Missouri River, is mantled by a morainal complex that during the recession of the ice was channeled by meltwater. The till of the morainal complex is stony silty clay that generally is less than $30 \mathrm{~m}$ thick, but over a considerable area west and south of Minot is more than $30 \mathrm{~m}$ thick, and locally more than $90 \mathrm{~m}$ thick (Andrews, 1939, p1. II).

The area of the Central Lowlands included in the area of this report is completely mantled by ground moraine and glaciolacustrine deposits as well as some glaciofluvial deposits. The ground moraine here too is stony silty clay, less than $45 \mathrm{~m}$ thick in most places (Lemke, 1953). 
Alluvium (Pleistocene and Holocene).--Flood-plain and terrace deposits of the modern streams are composed mostly of sand, silt, and clay. Gravel is a minor constituent of the alluvium in most places, and it occurs mainly in point bars of the Missouri River and in some low outwash terrace deposits that may be considered part of the alluvium. Landslide deposits (Holocene).--Landslides as a geologic hazard are discussed in more detail elsewhere in this report. Slumping and landsliding generally are common in areas underlain by clayey silty sedimentary rocks like those that characterize the basin-fill of the Williston Basin, particularly where high slopes or bluffs are undercut, or are oversteepened because of a resistant capping layer such as the clinker beds or some of the sandstone beds.

The landslide deposits are unsorted jumbled masses of the parent formation. Lithologies are varied, depending on the character of the bedrock, but the disrupted churned-up character of the internal structure of the mass is common to nearly all landslide deposits, regardless of their type. Some very large slumps maintain the integrity of their internal structure in the rotated slide block. In earthflow, the materials become thoroughly mixed. 
STRUCTURE

Williston Basin

The Williston Basin is an intracratonic structural basin in western North Dakota that extends westward into Montana, southward into South Dakota, and northward into Canada (fig. 7). Its center is south of

Figure 7.-NEAR HERE

Williston, North Dakota (U.S. Geol. Survey and Am. Assoc. Petroleum Geologists, 1961). The basin was initiated structurally in the early Paleozoic, and subsided nearly continuously throughout the Paleozoic, Mesozoic, and most of the Cenozoic (Carlson and Anderson, 1965, p. 1836; Carlson and Anderson, 1973a, p. 36-37). Deposition of basin-fill sediment ended in the late pliocene when the continental interior was epeirogenically uplifted. The Precambrian floor in the central area of the Wiliston Basin is more than 4,572 m $(15,000 \mathrm{ft})$ below sea level (Carlson and Anderson, 1973b, p. 43). Beds in the basin dip very gently toward its center, except where interrupted by folds. The regional dip in the Fort Union strata within the basin in North Dakota generally is between 1 and $10 \mathrm{~m}$ per $\mathrm{km}$ ( 5 and $50 \mathrm{ft}$ per mile) (Roe, 1950, p. 434) but may be as much as $35 \mathrm{~m}$ per $\mathrm{km}$ (180 $\mathrm{ft}$ per mile) (Brant, 1953, p. 13). 


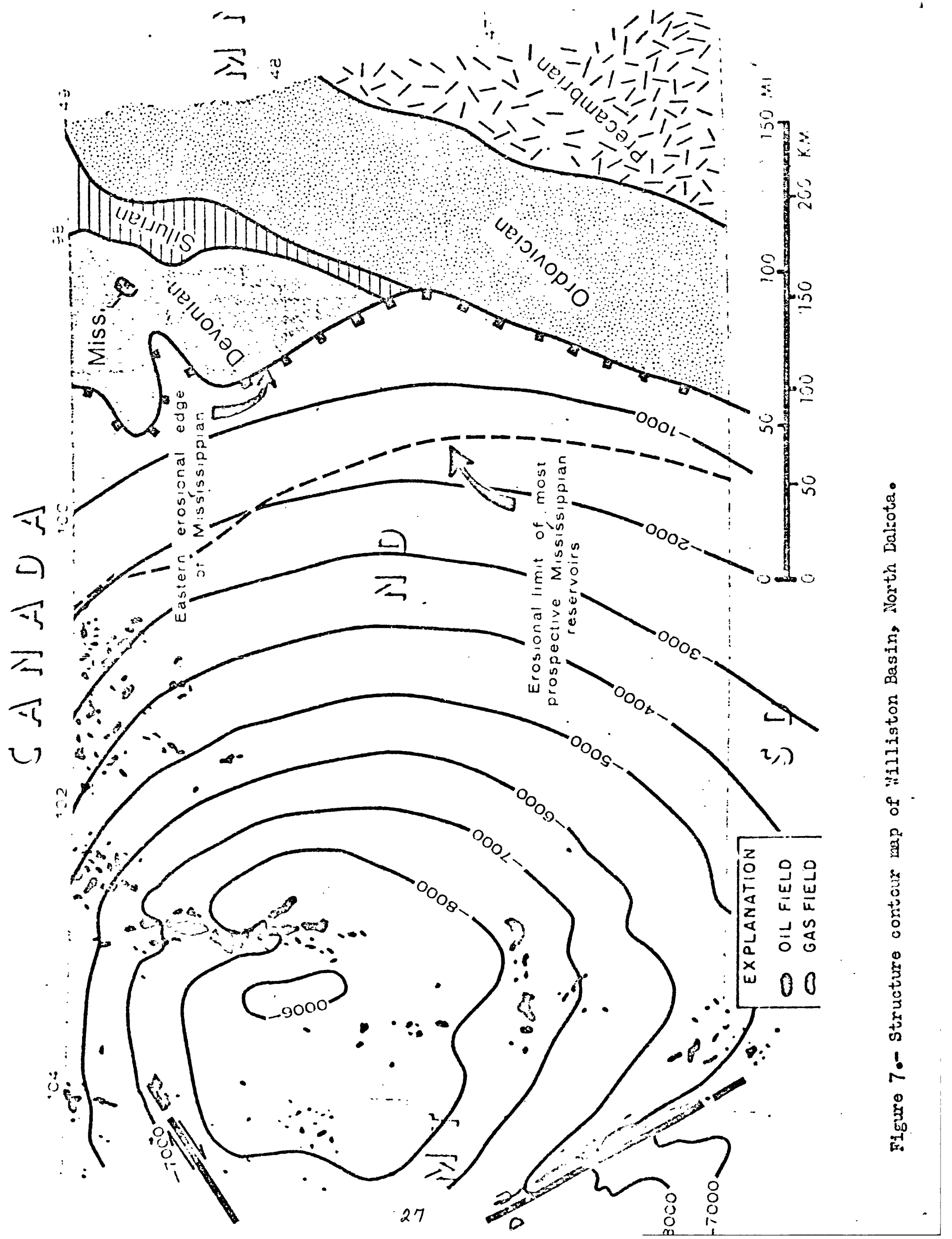


Folds.--Several major folds are imposed on the strata of the Williston Basin. The largest of these folds, the southeast-trending Cedar Creek Anticline (Dobbin and Larsen, 1936), is mostly in Montana, but it extends into Bowman County, in the extreme southwestern corner of North Dakota. East of Williston are the north-trending Nesson Anticline (Collier, 1919) and White Earth Syncline. The Keene Dome (Nevin, 1946) forms a southeast-trending branch of the Nesson Anticline south of the Missouri River. The northwest-trending Killdeer Syncline lies mostly south of the Little Missouri River. Two small nort'west-trending anticlinal folds lie near the State boundary west of Flat Top Butte, in McKenzie County (U.S. Geological Survey and American Association of Petroleum Geologists, 1961). Thomas (1974, p. 1318) considers the Nesson and Cedar Creek Anticlines to be intrablock drag folds formed by forces generated by the adjustments of basement blocks subjected to simple shear during Laramide compression. 
Fractures.--Faults are rare in western North Dakota, but a widespread lineament pattern (fig. 8) has been recognized by Thomas

Figure 8.--NEAR HERE

(1974). The lineaments, which are delineated by stream trends, topographic alinements, and tonal zones, form a northeast-northwest trending intersecting pattern that "is believed to be caused by the zonal arrangement of smaller fracture traces that cause differential erosion phenomena" (Thomas, 1974, p. 1306). The lineament pattern has been interpreted as a result of adjustments along basement weakness zones of a basement-block framework during Laramide time (Thomas, 1974, p. 1320). The block framework apparently adjusted laterally by simple shear to the compressive forces.

This regional fracture pattern may affect ground water movement, and is likely to be reflected in any presently unrecognized structures that offset the strata, including the lignite seams. 


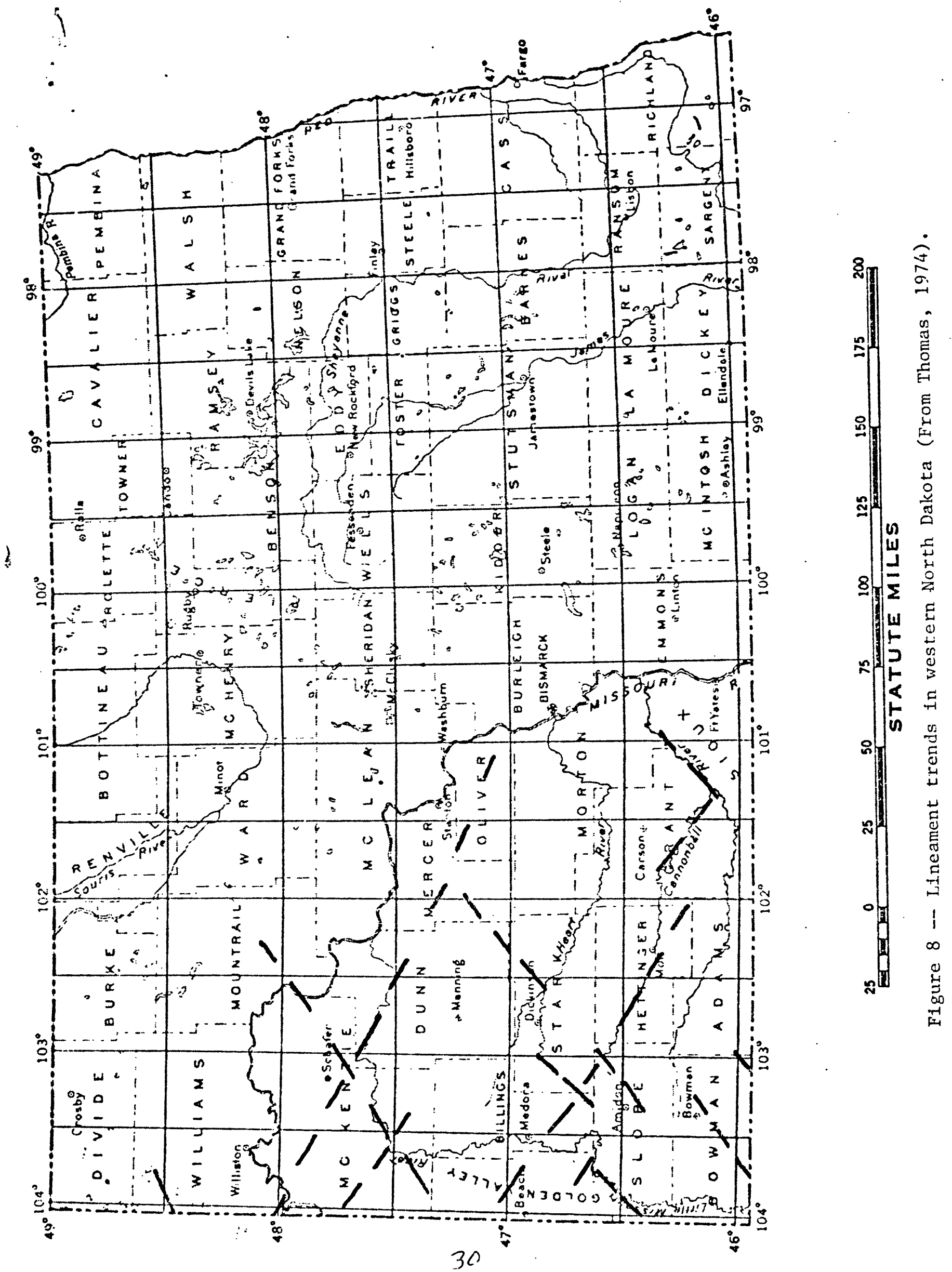




\section{LANDSCAPE GEOCHEMISTRY}

by

Jon J. Connor

The two greatest geochemical impacts on the western landscape as a result of large-scale coal development are likely to be geochemical alteration at strip-mine sites by overturn, and geochemical alteration adjacent to electric-generating sites by the products emitted by coal combustion. The first tends to be a rather localized effect but the second may have regio.ral impact.

Environmental interest in the chemical composition of the natural landscape is mainly concerned with the changes in chemical composition that may take place as a result of disturbing or restoring a landscape. This interest focuses primarily on the chemical potential of disturbed or restored materials to support a desirable vegetative cover, which in turn can support animal life, including animals used directly by humans.

If the area to be disturbed by mining or related activity presently supports vegetation, the chemical composition of the substrate (soil or rock) obviously meets at least the minimum requirements of this vegetation. Therefore, a primary geochemical need in impact assessment is a knowledge of the chemistry of these substrates in terns of geochemical backgrounds or baselines. Such baselines define the minimum levels of total nutrient elements, and maximum levels of toxic elements, to which this vegetation is exposed, although not necessarily to the extreme that this vegetation can endure. They also provide a basis for estimating the chemical potential of abandoned or reclaimed land to support the same vegetation. 
Many studies have shown that the elemental composition of bulk soil is only weakly reflected by element levels in plant tissue. Therefore, work in plant geochemistry should focus on levels in the plant that may be toxic to wildlife or domestic animals. The plants, by their very presence, demonstrate that any current levels of elemental concentration found in the supporting soil can be tolerated by the vegetation, so the major botanical problem then becomes whether or not such plants can be expected to grow on some new kind of substrate resulting from man's activities and whether or not such growth will result in changed tissue concentrations of elements.

The first part of this question can only be answered by a study of the geochemistry of the new substrate. The chemical composition of these materials may indicate levels of nutrient elements below, or levels of toxic elements above, the concentrations found in the original (native) substrate. It is true that chemical requirements or chemical tolerances of vegetation are deternined by the available amounts, not total amounts, of certain elements in the substrate, but the experimental difficulties of determining or stating in a general way the criterion of element availability without reference to species-selective membrane response make the concept very difficult or impossible to apply to native ecosystems. 
While nutrient deficiencies are not uncommon in the plant and arimal world, public concern over trace element impact of coal development tends to focus on element excesses (toxicities). The definition of what constitutes an excess in a landscape material is less difficult than that of the definition of availability, but it is nevertheless a difficult one. Ideally, an excess is that amount above normal, but because normal concentrations can and do vary over considerable ranges in nature, a normal concentration at one spot (or in one sample) might well be viewed as excessive at another nearby spot (or in another sample of the same or similar material).

Considerable evidence is available that shows that the range in normal concentrations in soil and plant tissue typical of the coal regions of Wyoming, Montana, and North and South Dakota is manifested largely at very local or short-range scale in nature (U.S. Geological Survey, 1974b, 1975, 1976a, 1977); that is, the range in concentration noted in a suite of samples from one localized area in the region (such as a strip mine), is likely to be similar to the range noted at other, far-distant, sites. Under such circumstances, an elemental excess may be viewed as concentrations above some upper limit typical of the normal range. 
A provisional limit for selected constituents in seven ordinary landscape materials of western North Dakota is shown on Table 1. Each limit is defined as a concentration above which only about one sample in 20 is expected to fall under natural conditions. Because of vagaries inherent in some estimates, limits judged to be less reliable are given to one significant figure only and placed in parentheses. Nevertheless, these limits may prove useful in assessing geochemical impact. For example, observed ranges in concentration of elements in 30 samples of largely unreclaimed spoil materials from the Velva, Kincaid, and Beulah mines, North Dakota are as follows: 


\begin{tabular}{|c|c|c|c|}
\hline & Kincaid & Velva & Beulah \\
\hline Al, \% & $4.7-8.7$ & $5 \cdot 5-7 \cdot 4$ & $7.0-8.7$ \\
\hline$c, \%$ & $1 \cdot 8-18$ & $1.2-8.1$ & $.29-8.7$ \\
\hline $\mathrm{Ca}, \%$ & $2 \cdot 3-5 \cdot 5$ & $2.6-3.7$ & $.73-2.8$ \\
\hline F, ppm & $400-1,600$ & $400-2,900$ & $600-1,100$ \\
\hline $\mathrm{Fe}, \%$ & $2 \cdot 2-3.7$ & $2 \cdot 1-2 \cdot 6$ & $1.7-4.7$ \\
\hline $\mathrm{Hg}, \mathrm{ppm}$ & $.02-.1$ & $.04-.05$ & $.007-.12$ \\
\hline $\mathrm{K}, \%$ & $1.4-2.1$ & $1.4-1.7$ & $1 \cdot 6-2 \cdot 1$ \\
\hline Li, ppm & $14-32$ & $21-33$ & $16-29$ \\
\hline $\mathrm{Mg}, \%$ & $1.1-1.7$ & $1.1-1 \cdot 6$ & $.79-1.6$ \\
\hline Mn, ppm & $290-560$ & $200-340$ & $110-790$ \\
\hline $\mathrm{Na}, \%$ & $.90-1.4$ & $.44-1.3$ & $.57-1.5$ \\
\hline $\mathrm{Rb}, \mathrm{ppm}$ & $38-76$ & $47-75$ & $49-87$ \\
\hline s, \% & $.027-.74$ & $.027-.16$ & $.16-1.1$ \\
\hline $\mathrm{Si}, \%$ & $20-30$ & $26-31$ & $22-34$ \\
\hline Th, $\mathrm{ppm}$ & $7 \cdot 4-14$ & $5.8-8 \cdot 3$ & $5 \cdot 5-10$ \\
\hline $\mathrm{Ti}, \%$ & $.21-.40$ & $.23-.30$ & $.32-.40$ \\
\hline $\mathrm{U}, \mathrm{ppm}$ & $1.8-4.7$ & $2.1-3.2$ & $2.3-3.7$ \\
\hline $\mathrm{Zn}, \mathrm{ppm}$ & $43-110$ & $56-71$ & $68-100$ \\
\hline
\end{tabular}

Mercury, in particular, seems anomalously high in these samples compared to baseline data of table 1 .

Table 1.--NEAR HERE 
Table 1. Probable upper limits of concentration to be expected in ordinary landscape materials of the Northern Great Plains

[The limits are estimated as those above which only about one sample in 20 of a randomly collected suite is expected to fall due to natural causes alone. Values expressed as parts per million (milligrams per liter in water) except as indicated. Limits given to two significant figures except those in parentheses, which are given to only one significant figure because they are judged to be less stable. Leaders (--) indicate data insufficient Lo estimate limit.]

Landscape Material $1 /$

Property

Rock Soil Sediment Ground Wheat 2 /

Shale Sandstone

water
(1)
(2)
(3)
(4)
(5)
(6)

(7)

\begin{tabular}{|c|c|c|c|c|c|c|c|}
\hline$A l, \%-\cdots$ & -- & - & (7) & (8) & - & $70 \times 10^{-7}$ & -- \\
\hline As, & - & - & -- & -- & - & - & -- \\
\hline B- & -- & - & 79 & 91 & -- & .91 & -- \\
\hline $\mathrm{Ba}-\cdots$ & - & - & - & -- & - & .024 & - \\
\hline Be- - & $-\infty$ & - & - & 2.6 & -- & - & - \\
\hline $\mathrm{Br}-\cdots$ & - & -- & - & -- & -- & 1.1 & -- \\
\hline$C($ total $), \%-$ & 5.3 & -- & $(10)$ & (6) & (5) & -- & -- \\
\hline $\mathrm{Ca}, \%$ & - & -- & 3.5 & (15) & -- & $(.02)$ & -- \\
\hline Cd-- & - & -- & - & -- & -- & - & $(.1)$ \\
\hline $\mathrm{C} 1$ & - & -- & - & -- & -- & .012 & - \\
\hline $\mathrm{Cr}-\cdots$ & - & -- & -- & 82 & -- & -- & $(.03)$ \\
\hline Co- & -- & -- & 11 & 12 & - & -- & $(.06)$ \\
\hline $\mathrm{Cu}-\cdots$ & - & -- & 38 & 35 & -- & -- & (5) \\
\hline F-- - - - & - & -- & 36 & - & - & (4) & (1) \\
\hline
\end{tabular}


Table 1. Probable upper limits of concentration to be expected in ordinary landscape materials of the Northern Great Plains--Continued Landscape Material $1 /$

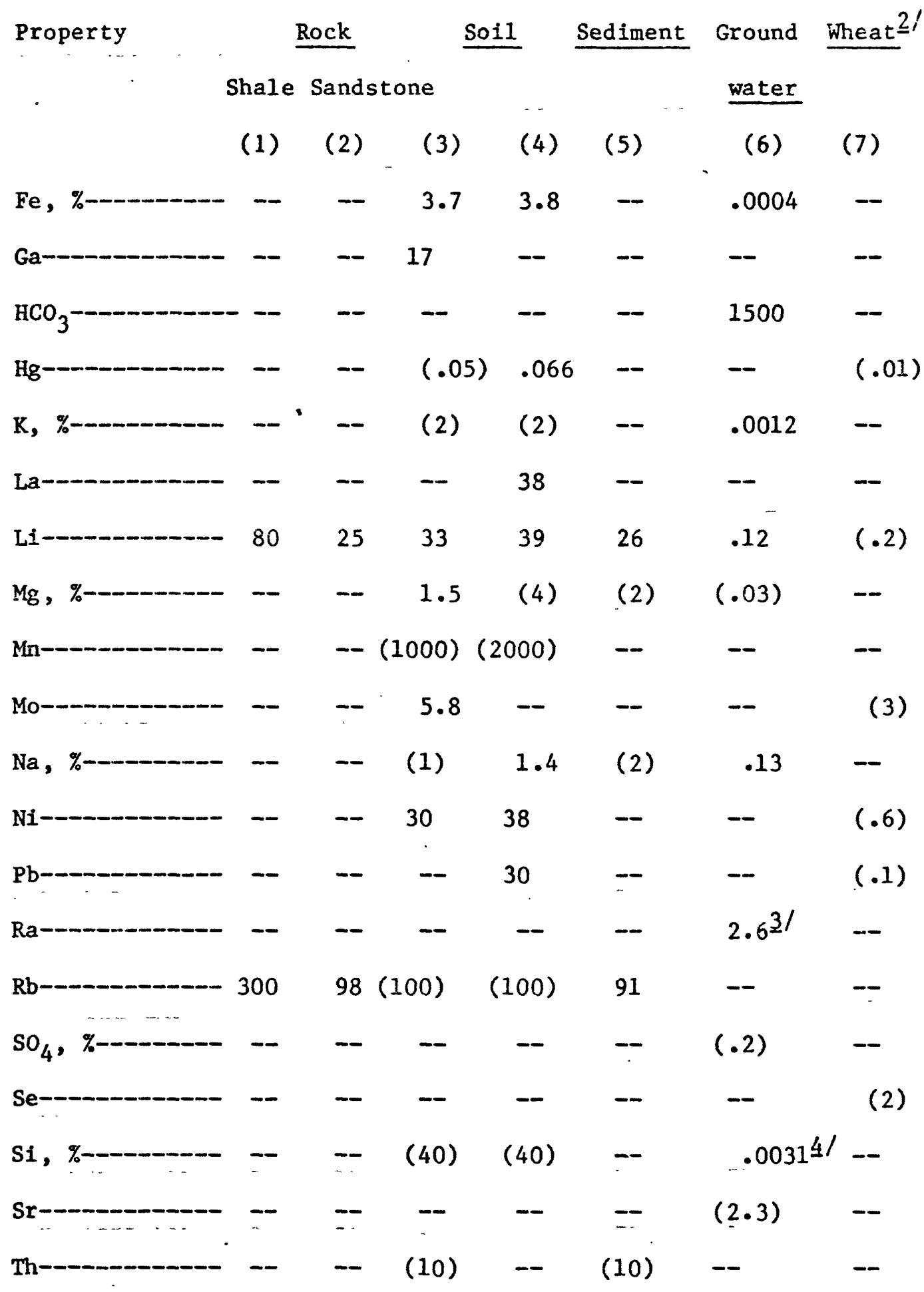


Table 1. Probable upper limits of concentration to be expected in ordinary landscape materials of the Northern Great Plains--Continued Landscape Material $1 /$

Property Rock Soil Sediment Ground Wheat 2 / Shale Sandstone water
(1)
(2)
(3)
(4)
(5)
(6)
(7)

\begin{tabular}{|c|c|c|c|c|c|c|c|}
\hline Ti, \%-- & - & -- & 1.2 & 1.6 & - & - & -- \\
\hline U-- & - & -- & (4) & (5) & (6) & $(.05)$ & -- \\
\hline V-m-n-m & -- & - & - & -- & - & -- & $(.02)$ \\
\hline Y-D- & - & - & 27 & 27 & - & - & -- \\
\hline 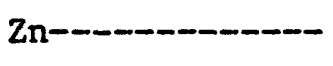 & 220 & - & $(100)$ & $(87)$ & 95 & $(.9)$ & $(50)$ \\
\hline $\operatorname{Rad}^{5 /} \ldots$ & -- & - & $(50)$ & - & -- & -- & -- \\
\hline
\end{tabular}

Alkalinity

(1000)

Dissolved solids $\left(180^{\circ} \mathrm{C}\right)$

.3000

Hardness (Total as $\mathrm{CaCo}_{3}$ )

(2000)

Temperature, ${ }^{\circ} \mathrm{C}$

14

pH (standard units)

8.9

Gross

$15^{3 /}$

Specific conductance, micromhos/cm

(4000)

Sodium absorption ratio

(100)

$1 /$ Identification of landscape materials and sources of data (references at end of footnotes).

(1). Fort Union Formation, outcrop (USGS, 1976a, table 14). .... (2) Do.... 
Table 1. Probable upper limits of concentration to be expected in ordinary landscape materials of the Northern Great Plains--Continued

(3) "A-horizon", <2 mm fraction (USGS, 1976a, table 9, figs. 15-27).

(4) "B-horizon", <2 mm fraction (USGS, 1976a, table 9, figs. 15-27).

(5) <150 fraction (USGS, 1976a, table 3).

(6) From domestic or livestock wells, average depth $30 \mathrm{~m}$ (USGS, 1976a, table 13).

(7) Grains of Triticum aestivum and T. durum (Shacklette and others, - 1976).

2/. Determined on dry weight.

3/ Radioactivity in picocuries per liter.

4/ As $\mathrm{SiO}_{2}$.

5/ Radioactivity in picocuries/gram. Computed as 4.81 (ppm U) +1.1 (ppm Th) $+8.5(\% \mathrm{~K})$. From John Rosholt (U.S. Geological Survey, written commun., 1976a). 
A miscellaneous collection of landscape materials from 25 counties composing the coal province in western North Dakota, however, has maximum observed concentrations greater than the upper limits of A-horizon soil (column 3 , table 1) for aluminum ( $\langle 10 \%)$, calcium $(>10 \%)$, iron ( $7 \%$ ), potassium ( $7 \%$ ), magnesium (5\%), sodium (3\%), boron (200 ppn), cobalt (30 ppm), copper (150 ppm), gallium (70 ppm), molybdenum (15 $\mathrm{ppm})$, and nickel (150 ppm). These differences suggest something of the magnitude of the geochemical impact of strip mining.

Mineral as well as chemical changes will also take place in the substrate if natural soil is replaced by or intermixed with overburden rock. Probably the most important result of such substitution arises from exposure of previously buried material to weathering, with the attendant possibility of chemical release of foreign substances into the surficial landscape. The most highly reactive materials occurring at the surface of overturned materials are expected to be fragments of coal or other highly carbonaceous strata and pyrite (found in both coal and sandstone). The bulk of such overturned material, however, will most likely be a mixture of fine-grained fragments of shale, siltstone, and claystone. The mineralogy of such a mixture would be rather simple consisting largely of quartz and clay minerals with more or less feldspar and carbonate minerals (U.S. Geological Survey, 1976a). Any chemical release from these materials under conditions of weathering is apt to be much slower than from the more reactive materials. 
In addition, the potential impact on vegetative cover is suggested in an examination of the copper/molybdenum ratio in sweetclover (Melilotus officinalis or M. alba) growing on these materials (table 2).

Table 2.--NEAR HERE

This ratio is seen to occur around $1-2$ in clover from the Velva, Kinkaid, and Beulah mines and compares with an optimal ratio in forage of about 5-7 (U.S. Geological Survey, 1976a). A browse diet formed largely of such a plant might induce symptoms of a copper/molybdenum imbalance in grazers. Grass (Bouteloua gracilis) in the Powder River Basin has ạn average ratio of 4.7 (U.S. Geological Survey, 1975, p. 17) and sagebrush (Artemisia tridentata) in the Green River Basin exhibits an average ratio of about 11 (U.S. Geological Survey, 1976a). Presumably such plants growing in North Dakota would have similar ratios. Wheat, although not a browse plant, has an average ratio of 4.6 (Shacklette and others, 1976).

Additional impacts have been observed in crested wheatgrass (Agropyron desertorum and A. cristatum) at the southern edge of the Powder River Basin (table 3). Expected concentrations (geometric means)

Table 3.--NEAR HERE

of cadmium, cobalt, fluorine, uranium, and zinc are higher in wheatgrass growing on reclaimed spoil materials than in the naturally growing control. Uranium, in particular is increased 4-fold. 


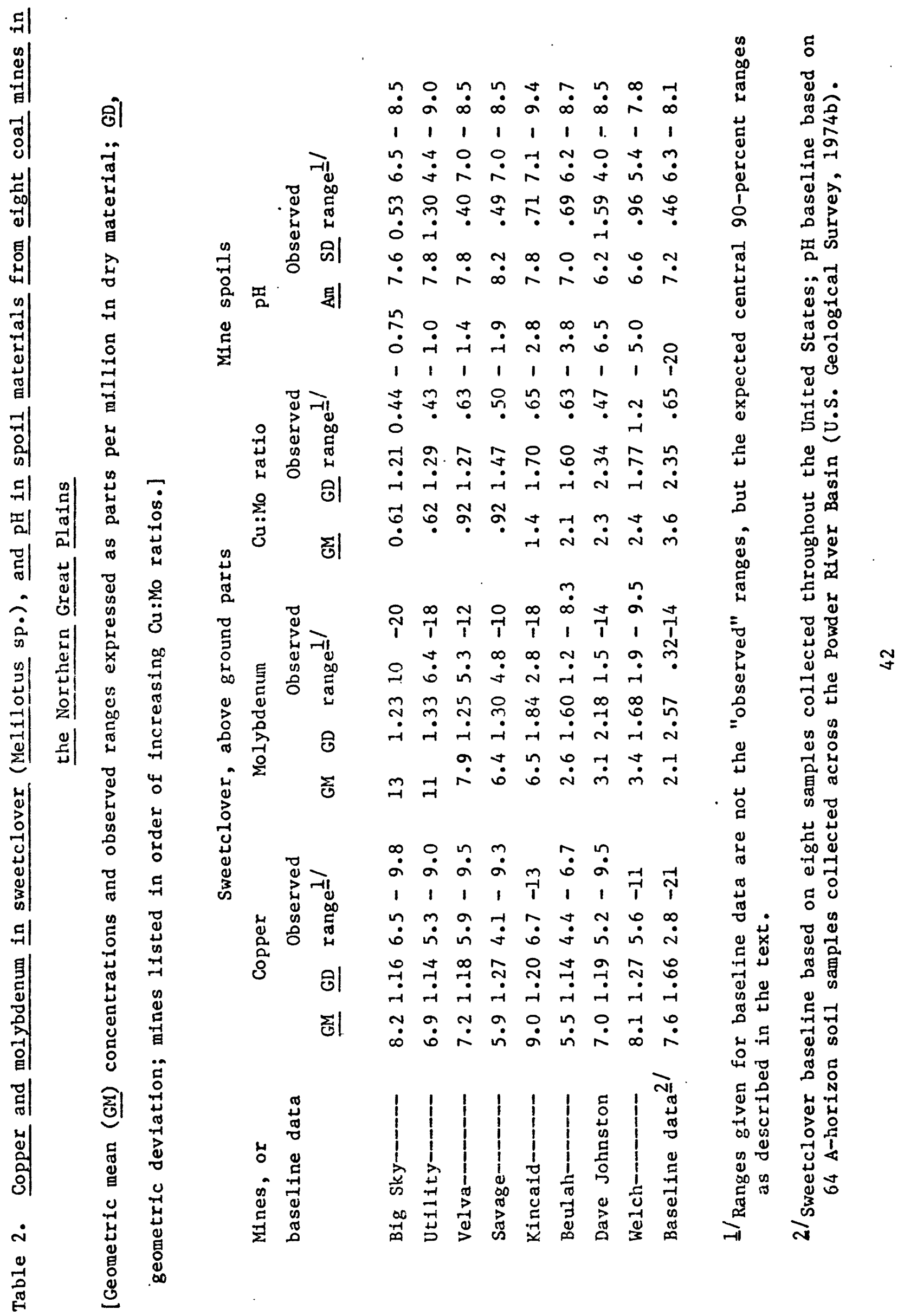


.

ฟั้

雚

일

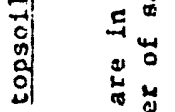

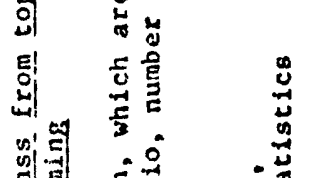

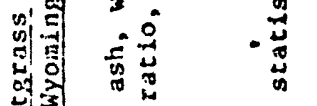

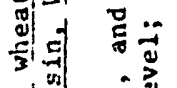

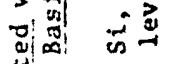

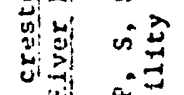

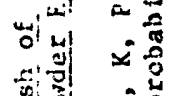

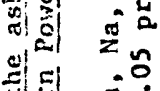

되데

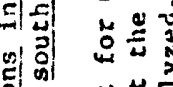

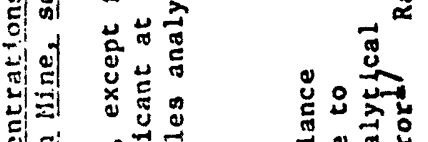

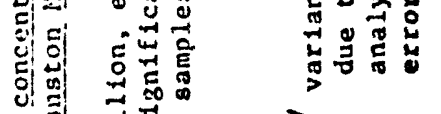

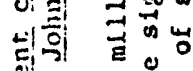

势

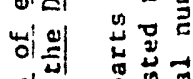

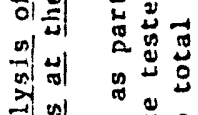

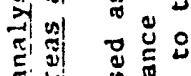

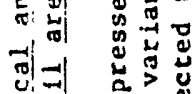

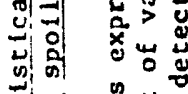

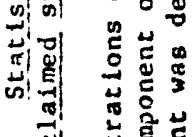

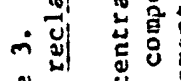

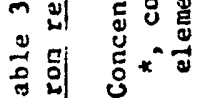

苟

今न

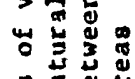

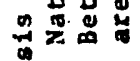

西

蒂票

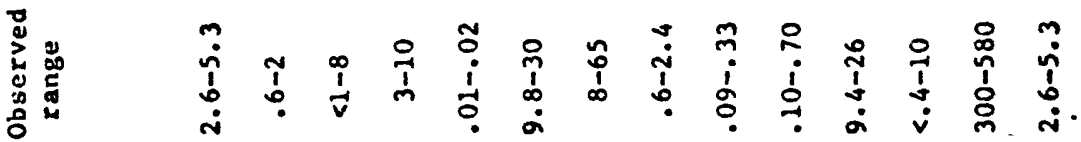

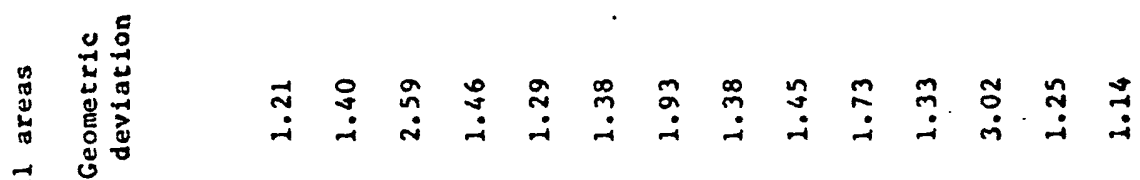

๓่

吾

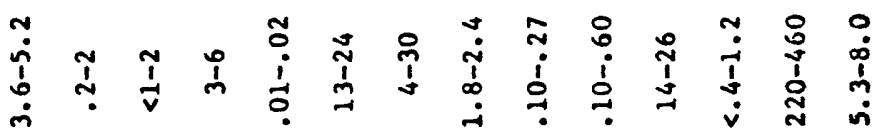

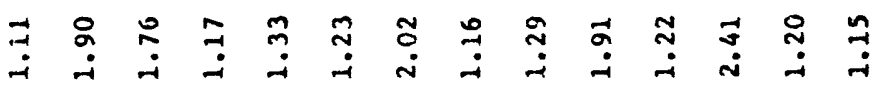

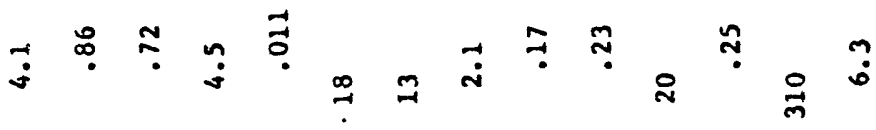

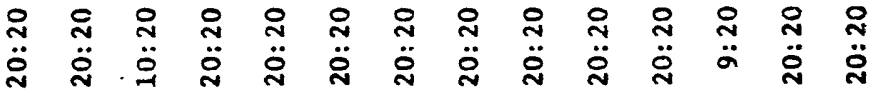

ก ก ก

莡

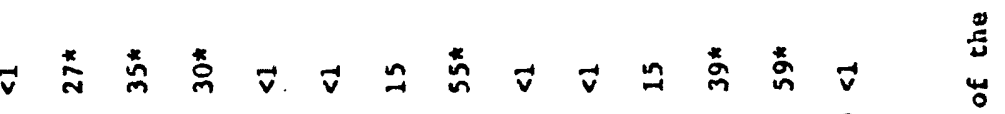

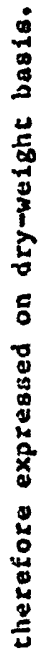

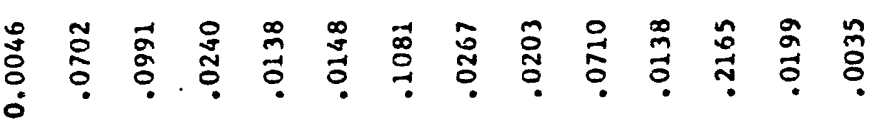

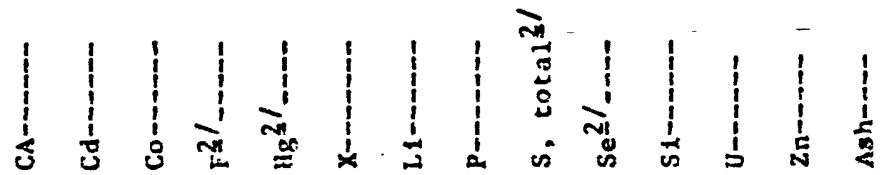


Regional geochemical impacts are likely to result mainly from windborne transport of extraneous materials. Two sources of such materials are unreclaimed or abandoned disturbed areas and stack emissions from coal-fired generating plants. Again, the focus of such - Impact is on potential changes in the vegetative cover. It is reasonable to suppose that powerplant emissions contain at least small amounts of every element naturally present in the lignite, but any practical assessment of their impact can only be based on elemental effects observed in the landscape adjacent to or downwind from the stack. Such effects were looked for in both sagebrush and soil lichen downwind from the Dave Johnston powerplant at the southern edge of the Powder River Basin (figs. 9 and 10). The strongest effect, as measured

Figures 9 and $10 .--N E A R$ HERE

by regression techniques, was due to selenium, a particularly important element because of its known toxic effects to browsers. In both vegetation species, selenium concentrations appear to be increased to distances of $5-10 \mathrm{~km}$ beyond the powerplant. Other suspect elements include strontium, vanadium, uranium, and fluorine and, perhaps, titanium, zinc, lithium, and cobalt. Except for uranium in sagebrush and selenium in lichen, the observed concentrations thought to reflect contamination are similar to or less than the upper limits for natural conditions given in table 1. In any event, the fears aroused by such accumulations reflect less a concern with absolute amounts introduced as with the availability to plants of such emissions. Because the lichen samples were cleaned prior to analysis, the selenium accumulation noted 
there probably reflects biological accumulation, not simple physical entrapment. 

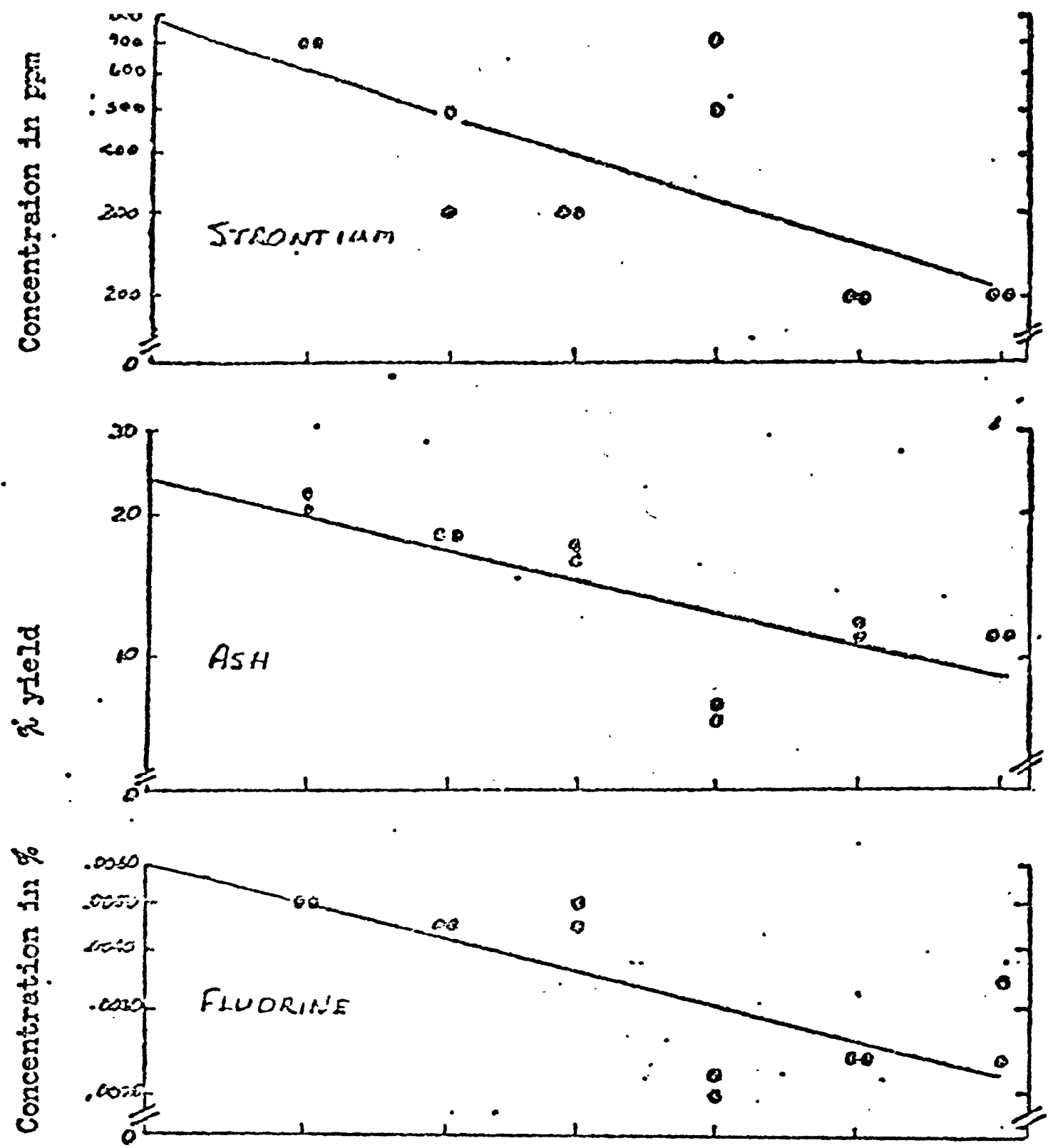

$x^{1}$

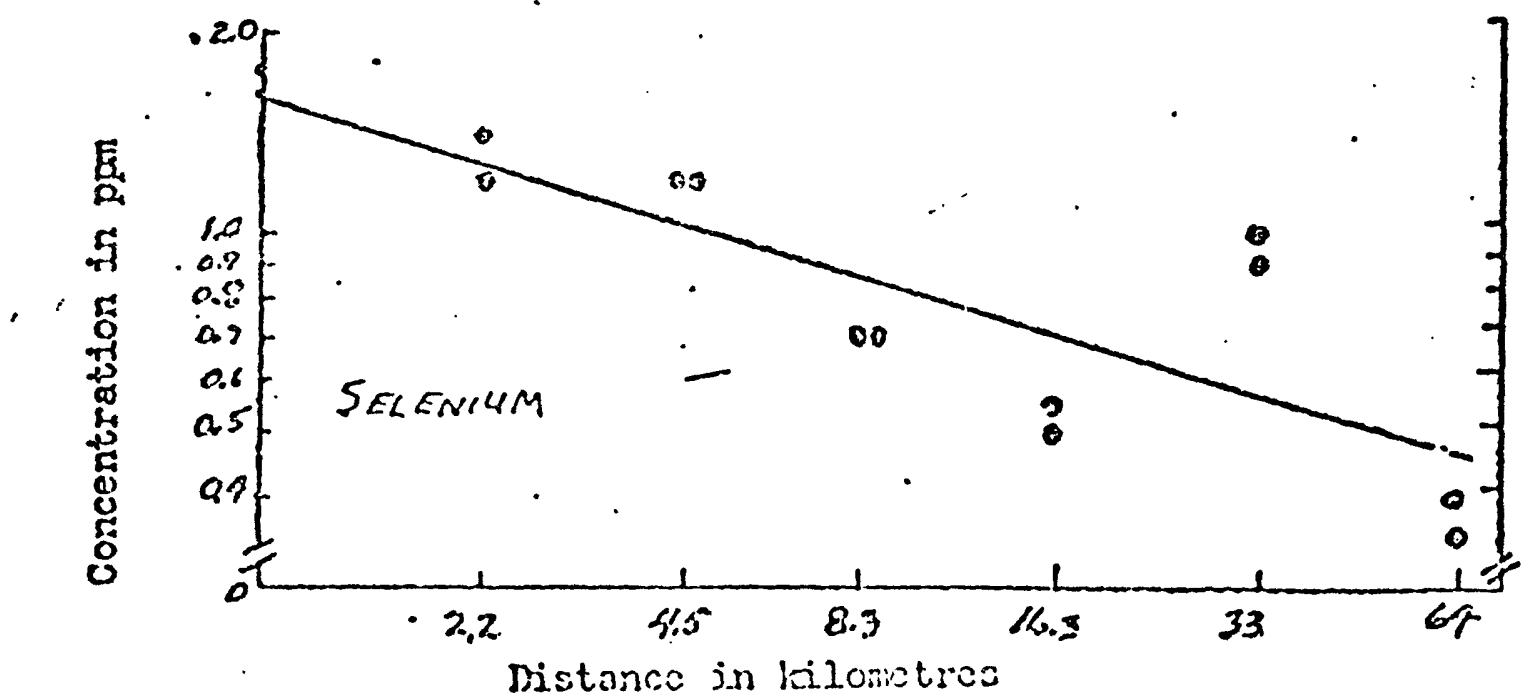

Figure 9. Regression trends in Parmelia chinrochroa for concentrations of fluorine, selonium, strontium, and ash progressing cast from the Dave. Jhuston power plant. Slopes are sienfficanty different from aco at the 0.01 probabllity level or less. 


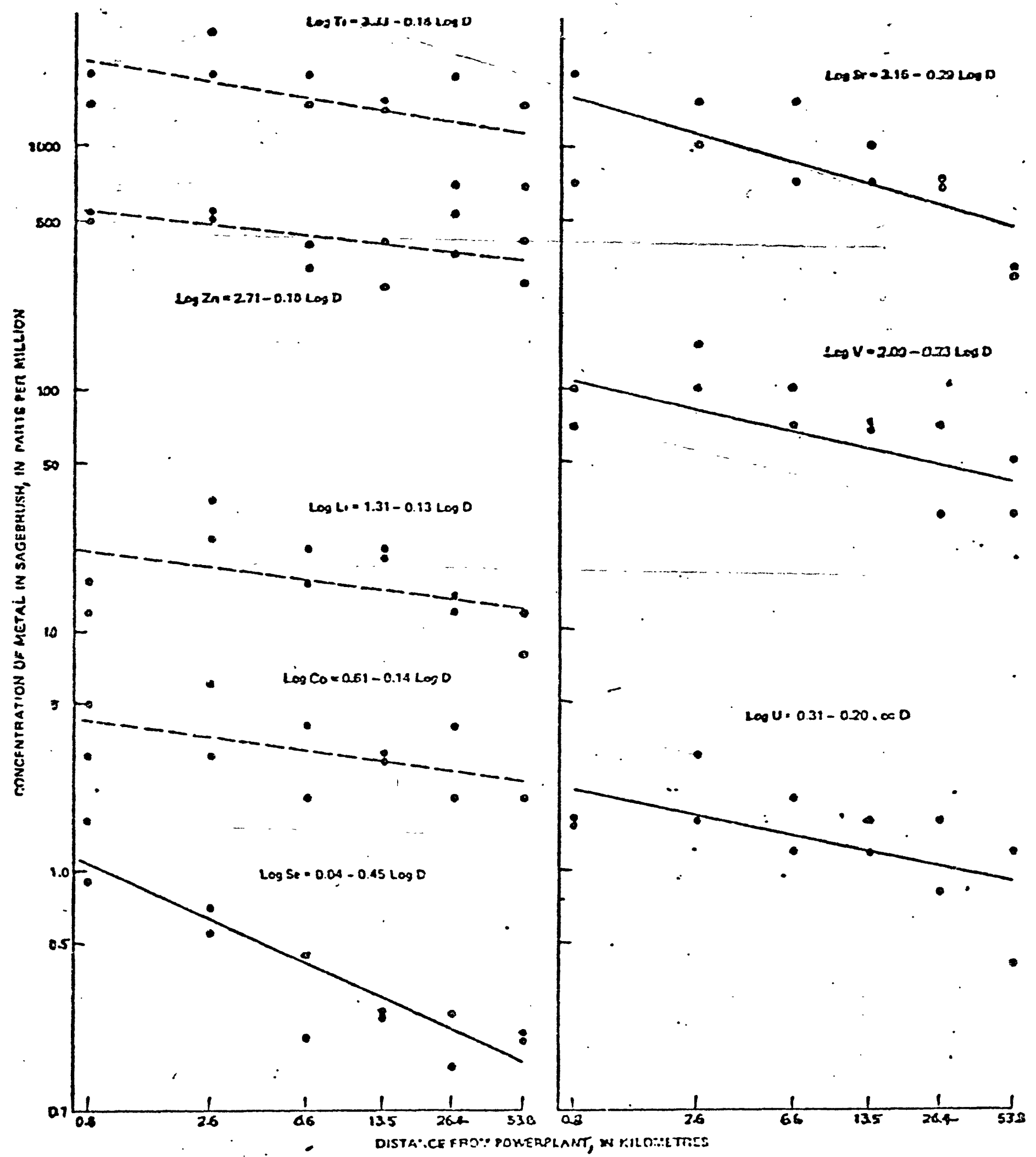

Figure 10. Metal trends in sagebrush away from powerplant. Slopes of solid regression lines are statisticdlly significant at the 0.05 or lower probability level of dashed lines at the 0.05 to 0.10 probability levels; both define trends in concentration. Concentrations of selenium measured in dry weight; all other concentrations measured in ash weight.

(Fron Connor and others, 1976). 
Presumably, the most abundant emissions from powerplants would be the oxides of sulfur, carbon, nitrogen, and hydrogen (water), but as essential constituents of vegetative tissue, it is unlikely that such impact on plant material could be measured as simple distance-related accumulation, although it might be measured in general terms of plant health. Interestingly, geochemical effects of power generation need not necessarily reflect only stack emissions. A sagebrush traverse north of the Jim Bridger powerplant indicated appreciable accumulations in sagebrush of iron, titanium, nickel, silicon, fluorine, and selenium, as well as, increased ash contents. All of these effects were measured before any of the generating units went on-line, and they tended to be greatest within $1-3 \mathrm{~km}$ of the plant. They probably reflect either a construction impact (windborne dust) or natural (substrate) fluctuations, or both (U.S. Geological Survey, 1976a). 
The hydrologic impact of energy development is expected to be substantial, although the greatest changes will likely be on the quantity or flow direction of water supplies, rather than on chemical quality, at least in a regional sense. Table 1 gives some expected upper limits of a variety of geochemical properties in the shallower (about $30 \mathrm{~m}$ ) domestic or livestock water supplies of the Northern Great Plains. Table 4 lists interim EPA standards for nine constituents in

Table 4.--NEAR HERE

primary drinking water as well as the maximum concentrations observed in the ground water study on which the data in table 1 are based. Except for measurements of radioactivity, the shallow ground water in North Dakota currently appears to be well within the interim limits. 
Table 4. Maximum element concentrations observed in shallow ground water from both domestic and livestock wells of the Northern Great Plains and 1isting of EPA interim standards for maximum concentrations permitted in primary drinking water (from U.S. Geological Survey 1976a, tables 13 and 14, and U.S. Environmental Protection Agency, 1975a, 1975b).

[All data expressed in milligrams per liter (mg/L) except where noted as picocuries/liter ( $\mathrm{pCi} / \mathrm{L})$.

\section{Constituent}

As

$\mathrm{Ba}$

Cd

$\mathrm{Cr}$

$\mathrm{Pb}$

$\mathrm{Hg}$

Se

Gross beta, pCi/1
Observed

0.026

.52

.001

$<.014$

$<.014$

.0001

.006

22

4.2
EPA interim standard

0.05

1.0

.01

.05

.05

.002

.01

22

3 
The most difficult aspect of impact assessment on the trace-element character of the landscape, however, is that of assessing the broadscaled regional effects. Although changes in trace-element concentrations far from mines or powerplants will almost certainly be very small, there is some concern that such changes may still pose a potential hazard to plant, animal, or human health. This is mainly because the exact roles played by many trace elements in living tissue are unclear or unknown, and the relation of the local geochemical environment on health or disease is even less well known (Hopps and Cannon, 1972; Cannon and Hopps, 1971). Moreover, such an assessment must be an interdisciplinary one. While it is the role of the natural scientist to determine the relative magnitude of man's contributions to the geochemical environment, it is the role of the medical scientist to deternine what, if any, health hazard may result from that contribution. 
PHYSICAL PROPERTIES OF THE FORT UNION FORMATION

by

E. E. McGregor, and W. K. Smith

Selected physical-properties tests on samples of the Fort Union Formation from four drill holes in the northern Powder River Basin in southeastern Montana show that, with few exceptions, the rocks of the Fort Union are so weak they cannot be tested as rocks but must be considered as strong soils. The rocks were tested at natural moisture conditions and, in general, the siltstones and shales at high moisture conditions behave plastically. Sandstone and silty sandstone with natural moisture either is plastic or crumbles when removed from a core barre1. Dehydrated surface exposures are cemented and hard, and do not reflect the character of the rock at depth. The rocks have very low tensile and compressive strengths, which suggests the need for careful design of slopes, mine faces, and pit floors. Mine slopes should be carefully designed even in strong rock. 
Fort Union rocks from the Decker mine area in southeastern Montana also were sampled and tested to determine their quantitative engineering properties. Properties which have been determined to date for several typical lithologies from the Decker mine include bulk density, confined (both peak and residual) and unconfined compressive strengths, Young's modulus, Poisson's ratio, and Brazilian tensile strengths. Results of triaxial tests are summarized in table 5, uniaxial (Poisson's ratio) tests in table 6, and Brazilian tension tests in table 7. Details of the physical property testing are given in Fahy and Smith (1976).

Tables 5, 6, 7.--NEAR HERE 


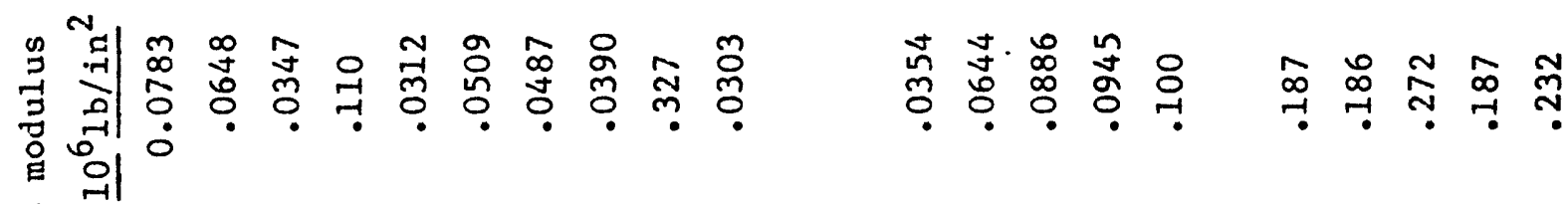

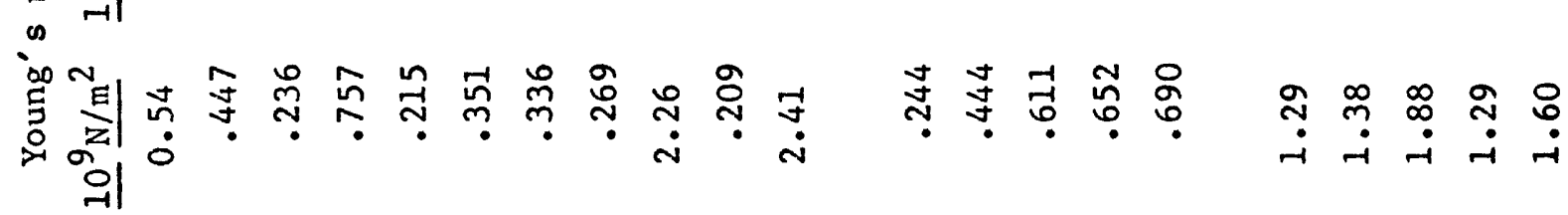

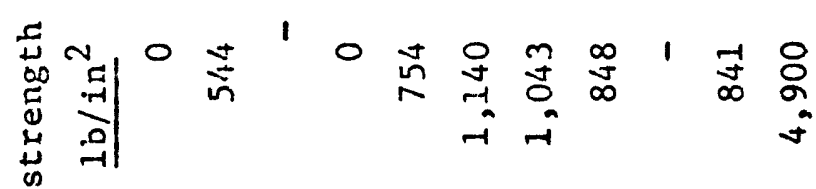

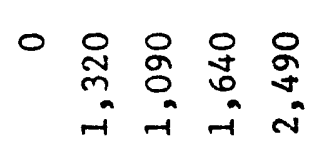

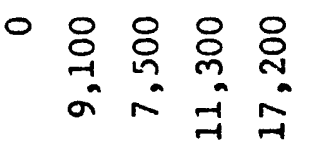

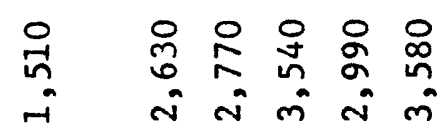

$\begin{array}{llllll}8 & 8 & 8 & 8 & 8 & 8 \\ + & 0 & 0 & 0 & 0 \\ 0 & 0 & 0 & 0 & 0 & \text { त }\end{array}$

in

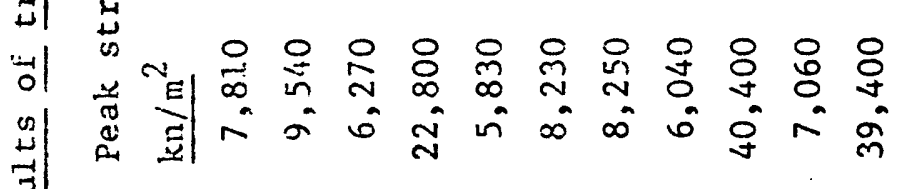

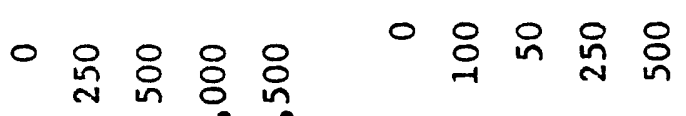

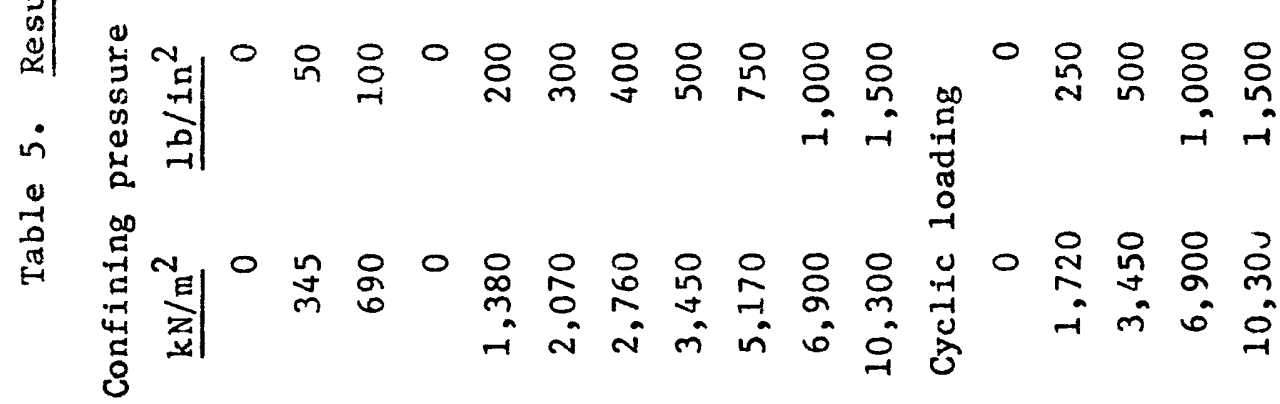

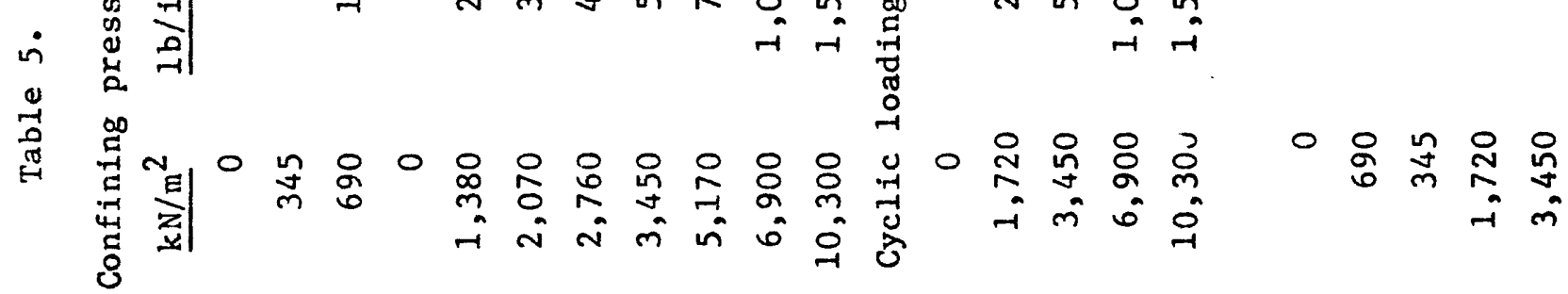

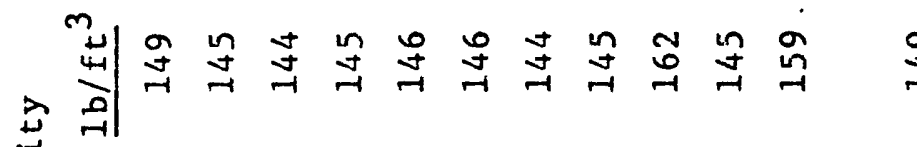

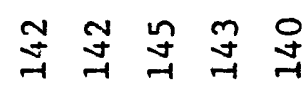

悹

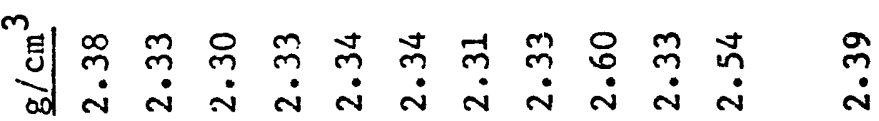

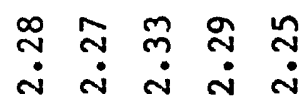

䓀

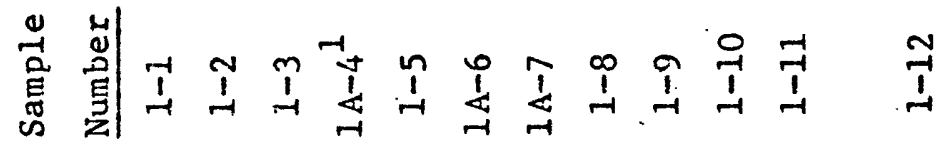

紊 


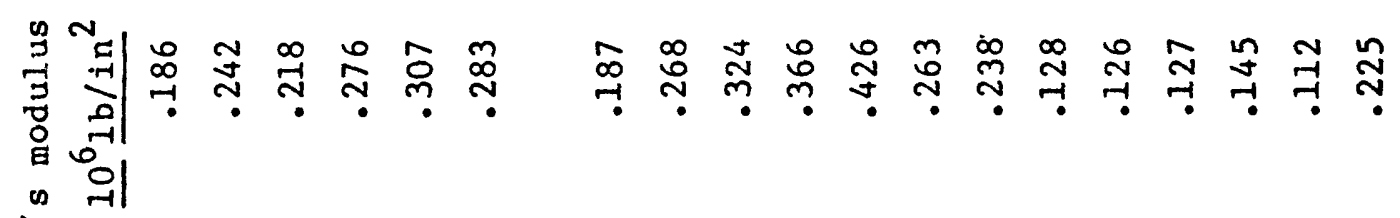

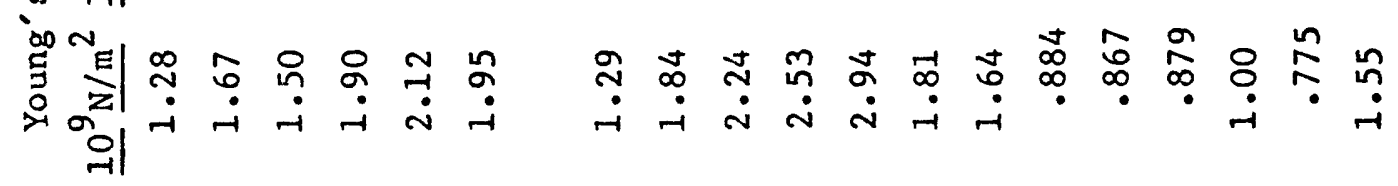

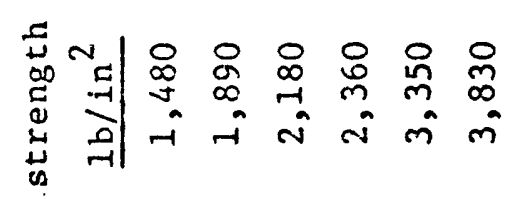

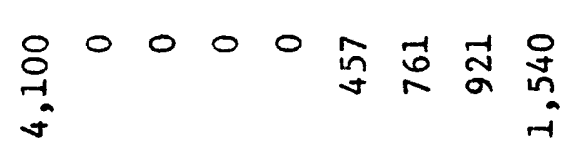

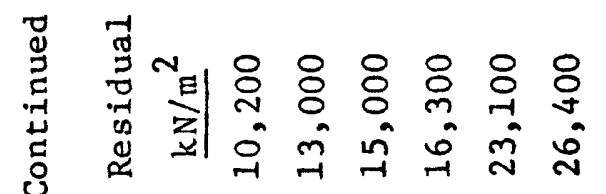

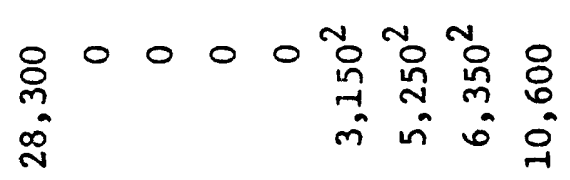

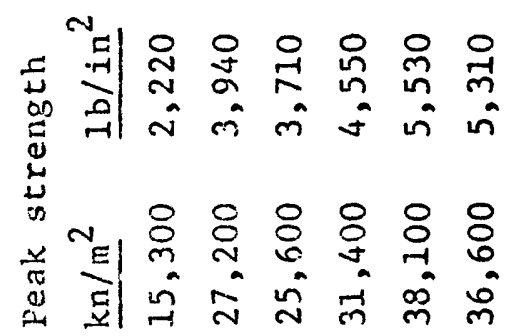

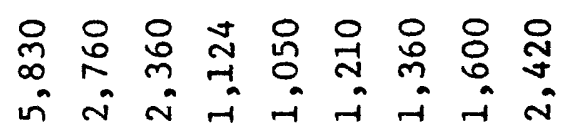

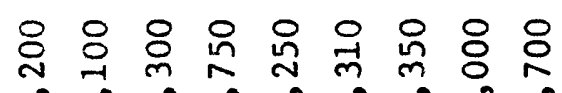

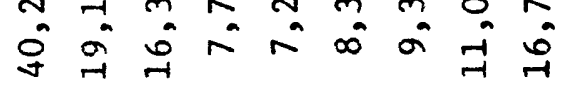

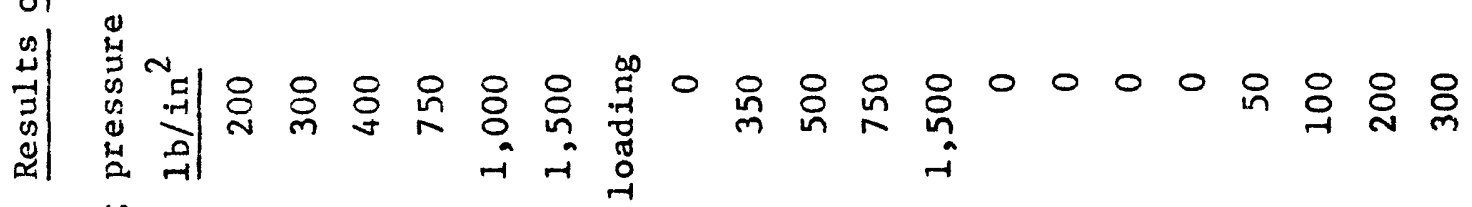

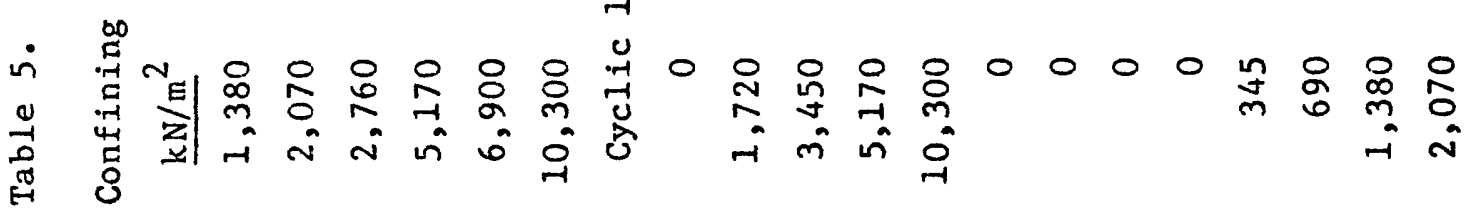

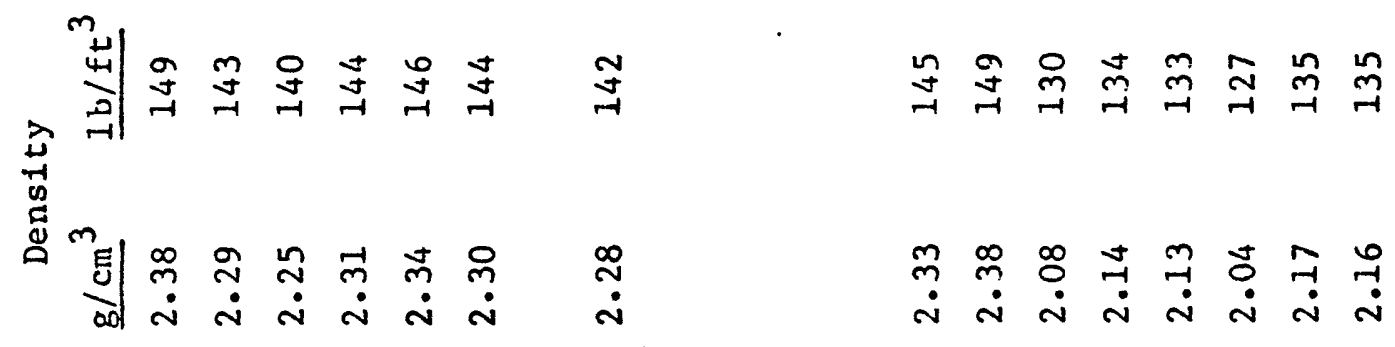
놀ㅊำ

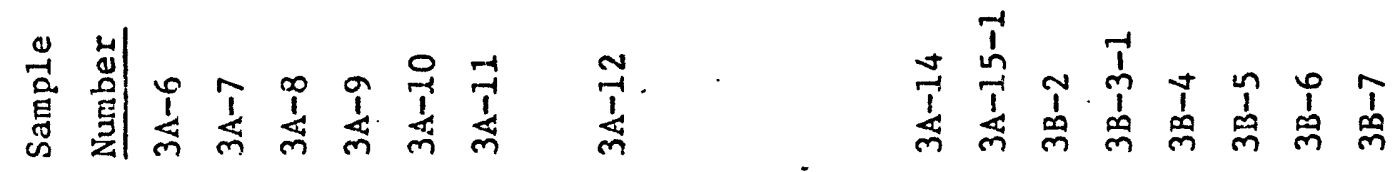




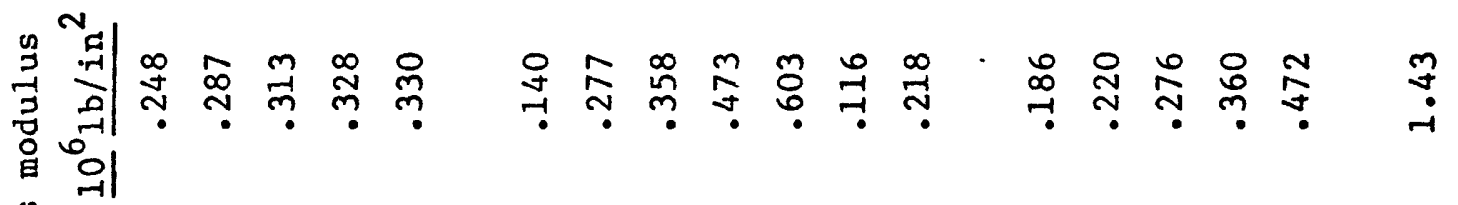
is $N$

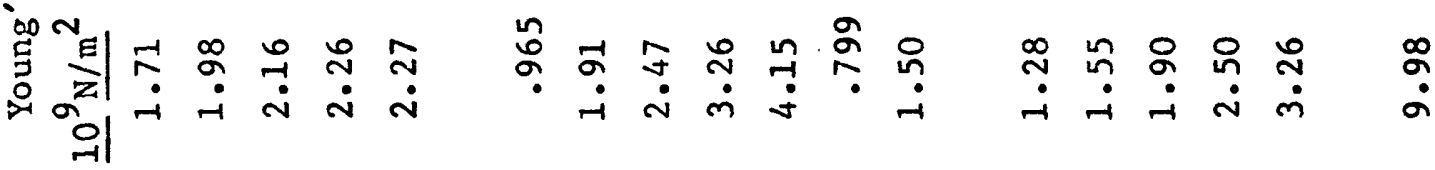

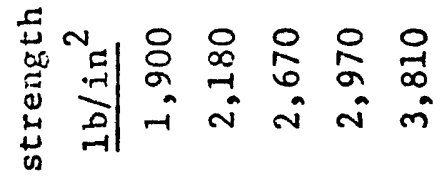<smiles>C1CCCCC1</smiles>

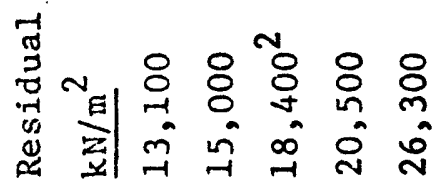

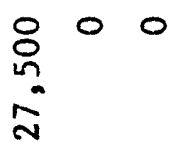

8
8
m

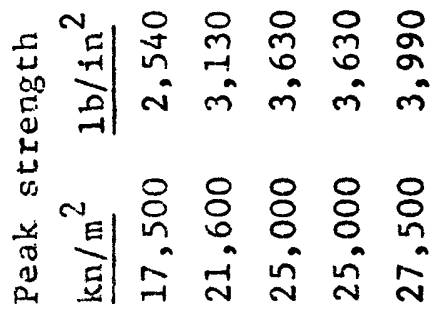

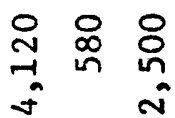

in

()

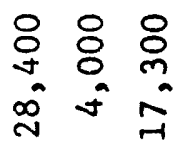

응
$\infty$
$\infty$

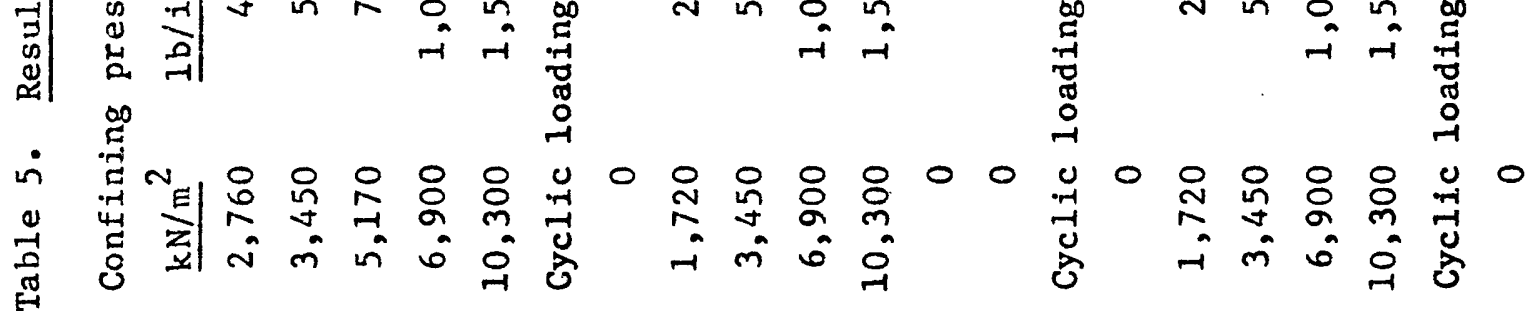

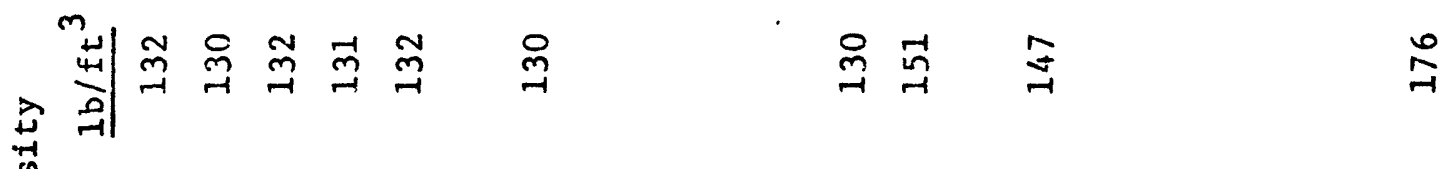

苟

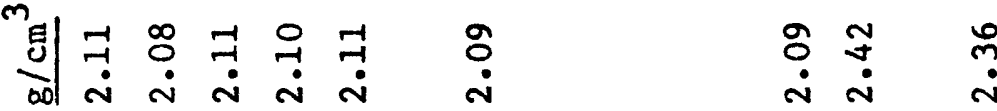

ஸ̃

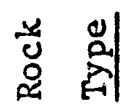

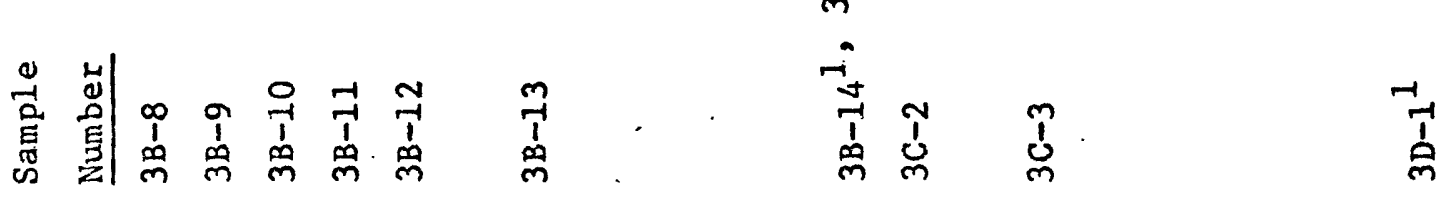




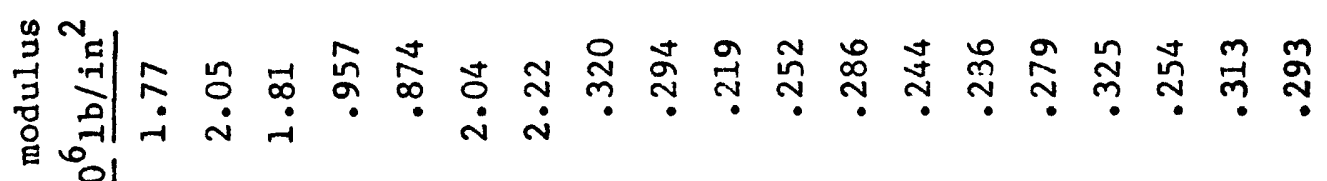

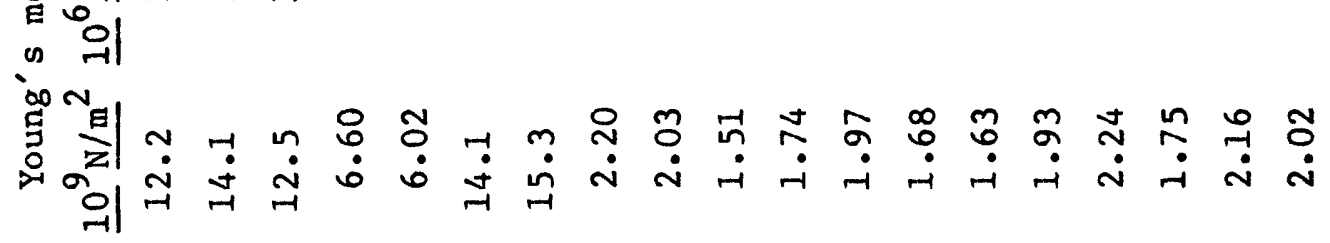

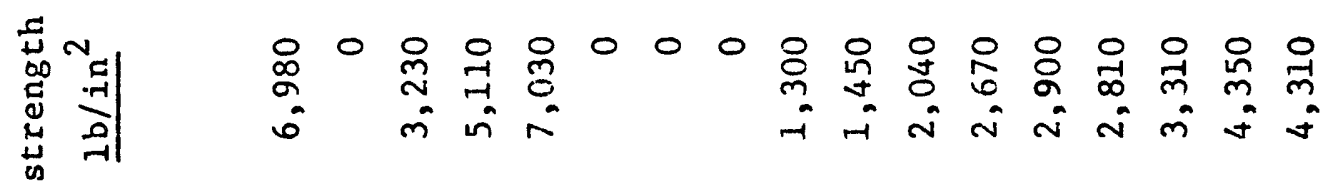

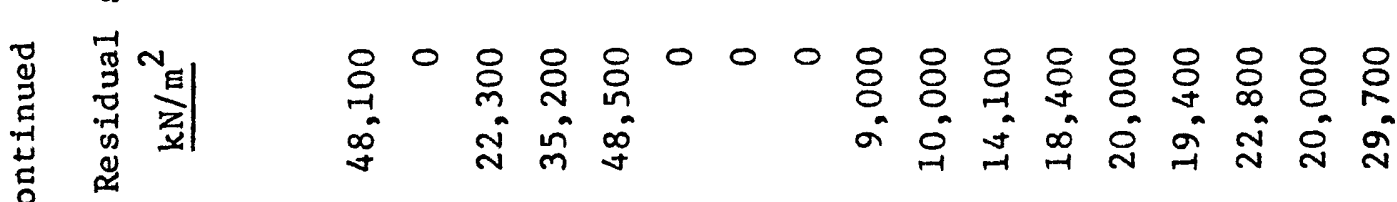

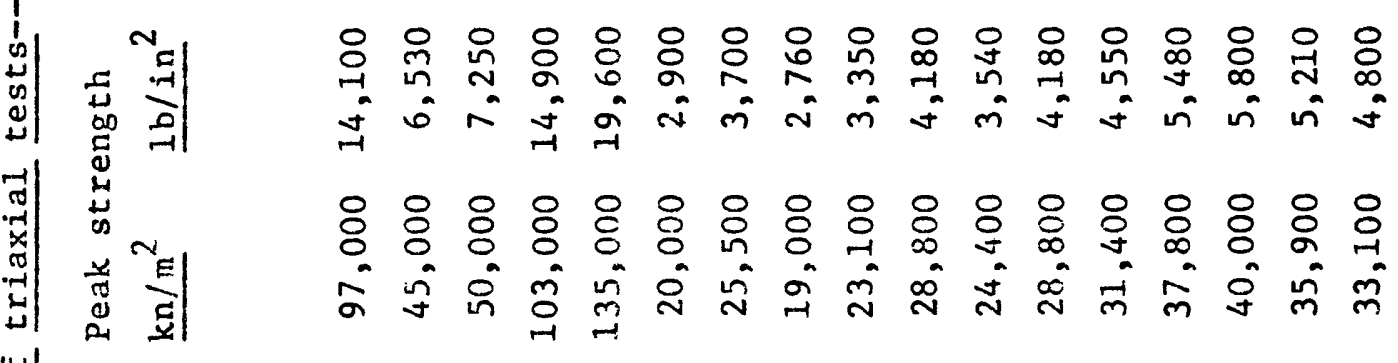

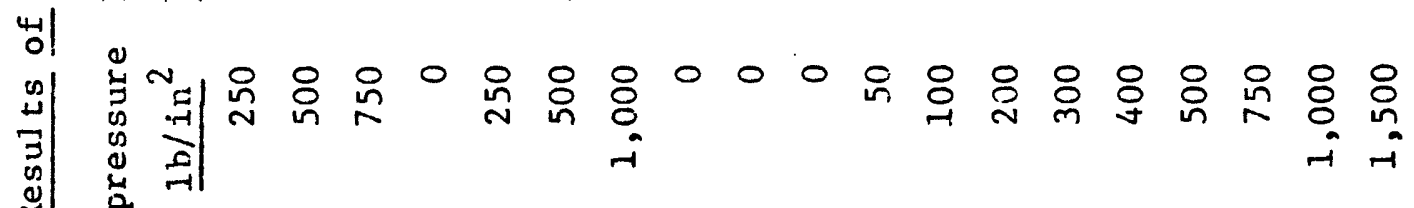

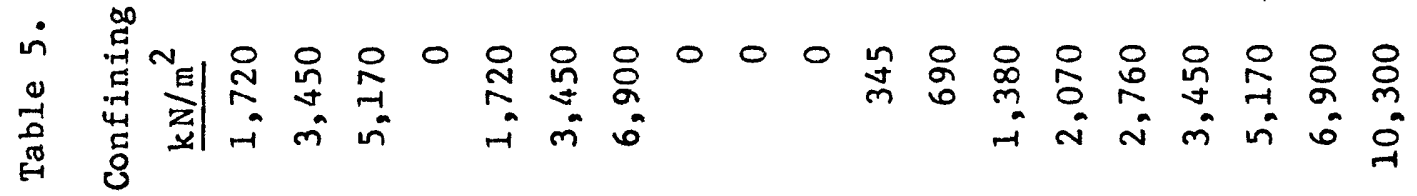

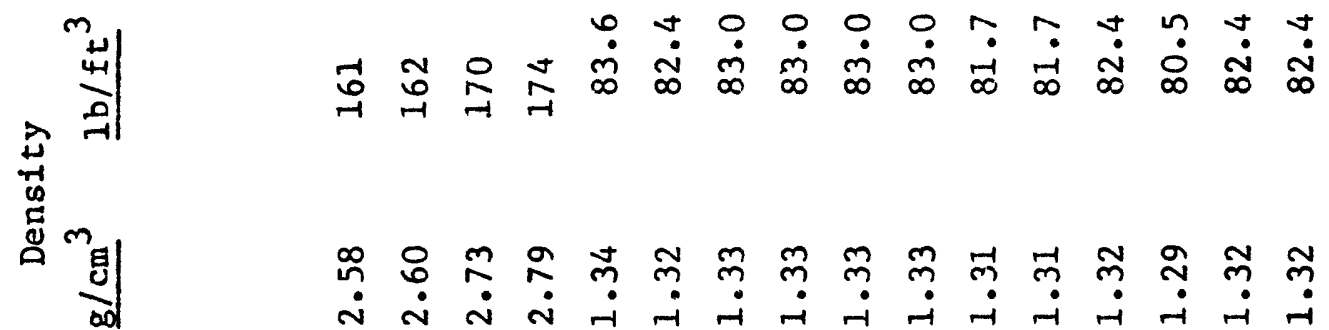
艺莃

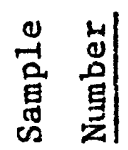
年 


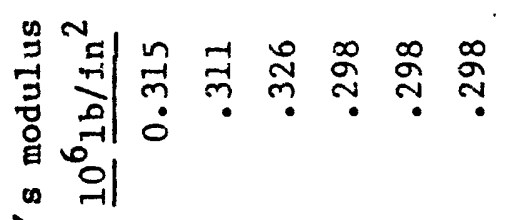

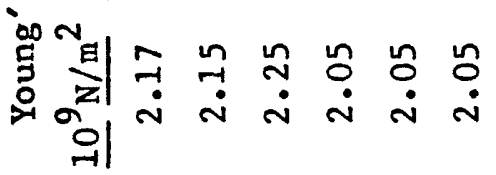

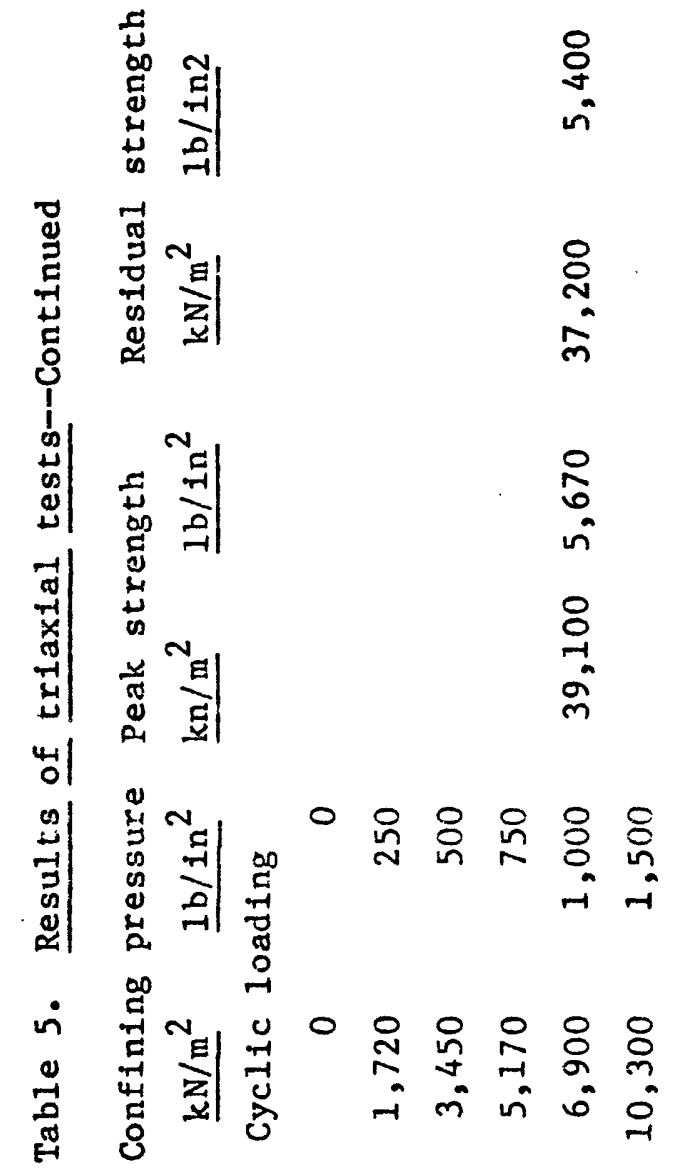

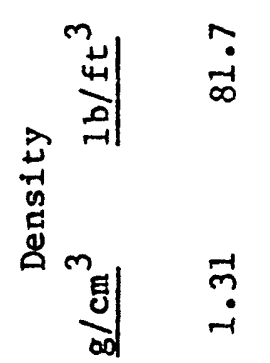

䓀

落

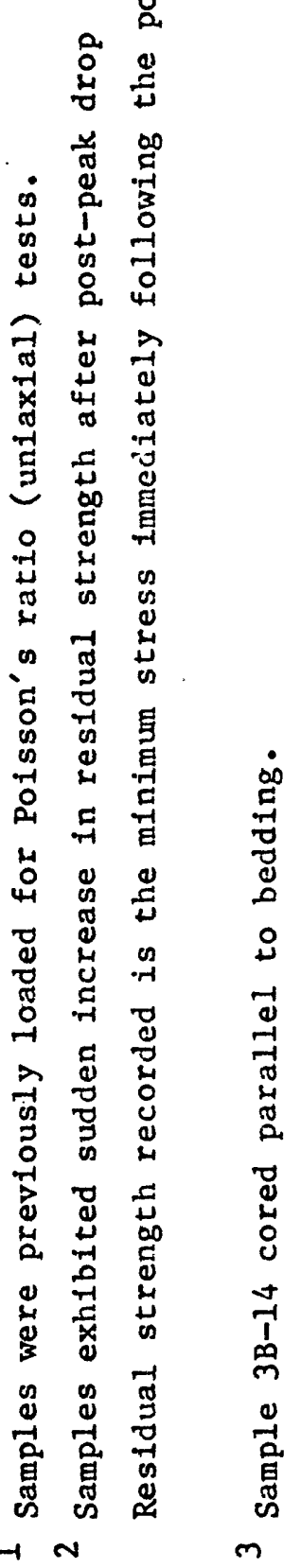


Table 6. Results of Poisson's ratio tests

\begin{tabular}{|c|c|c|c|}
\hline $\begin{array}{l}\text { Sample } \\
\text { Number }\end{array}$ & $\begin{array}{l}\text { Field } \\
\text { Location }\end{array}$ & $\begin{array}{l}\text { Rock } \\
\text { Type }\end{array}$ & $\begin{array}{c}\text { Poisson' } \\
\text { Ratio }\end{array}$ \\
\hline $1 A-4$ & $\# 1$ & Shape & 0.49 \\
\hline $1-13$ & $\# 1$ & Shale & .56 \\
\hline $3 A-13$ & \#3 & Shale & .15 \\
\hline $3 A-15$ & $\# 3$ & Shale & .44 \\
\hline $3 B-1$ & $\# 3$ & Siltstone & .57 \\
\hline $3 B-14$ & \#j & Siltstone & .36 \\
\hline $3 C-1$ & \#3 & Calcareous shale & .40 \\
\hline $3 D-1$ & \#3 & Limy siltstone & .81 \\
\hline $3 D-3$ & \#3 & Limy siltstone & .47 \\
\hline $4-1$ & $\$ 4$ & Coal & .36 \\
\hline $4-2$ & $\$ 4$ & Coal & .37 \\
\hline $4 A-3$ & $\$ 4$ & Coal & .43 \\
\hline
\end{tabular}

Note: -Sample 3B-14 cored parallel to bedding; all other samples were cored perpendicular to bedding.

-The high Poisson's ratios $(>0.5)$ are a consequence of dilatation during testing. 
Tatle 7. Results of Brazilian Cylinder tests

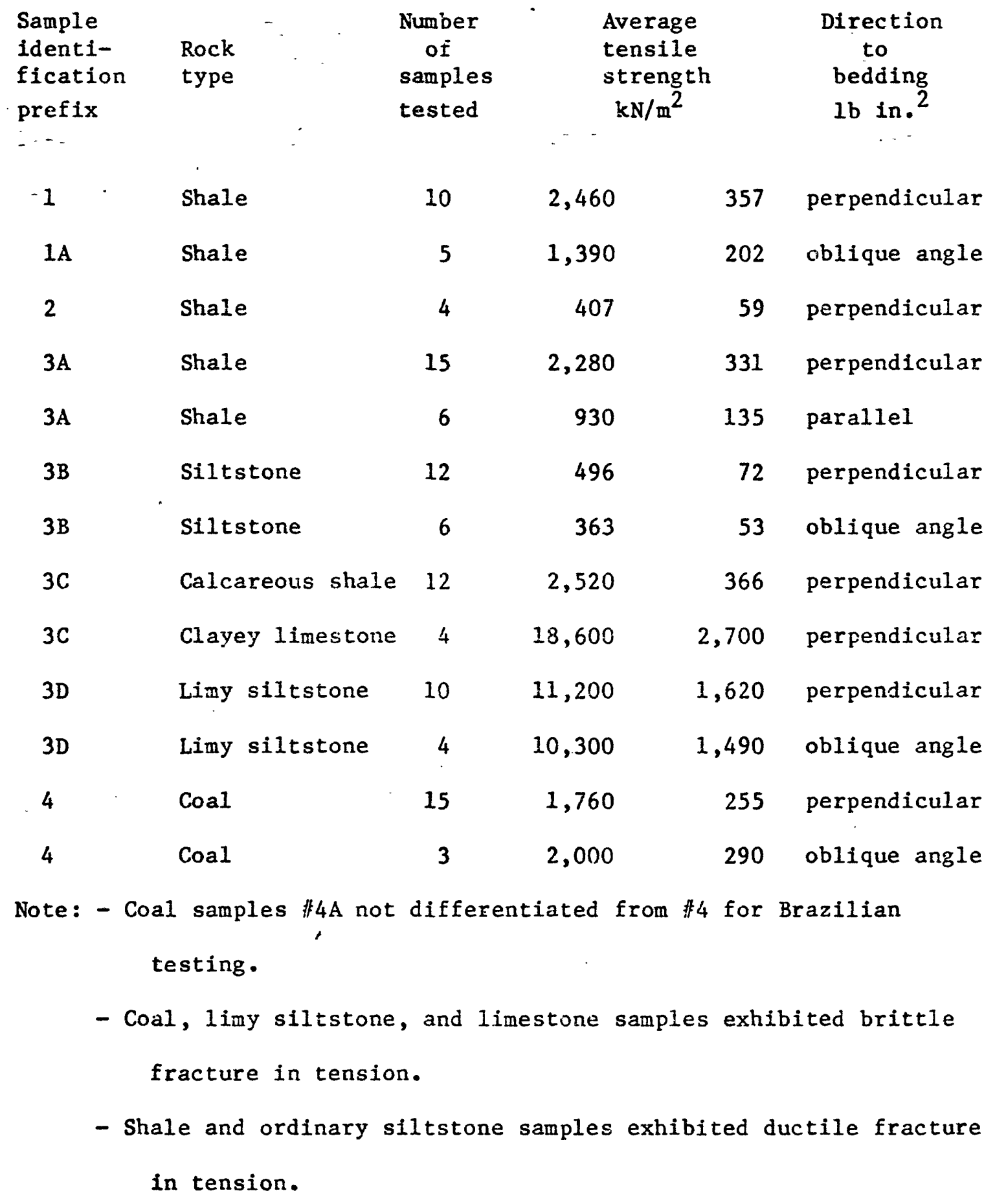




\section{GEOLOGIC HAZARDS}

Slope stability of the Fort Union Formation

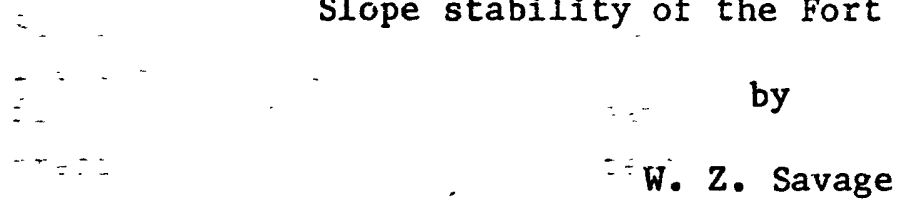

Slope stability of rocks of the Fort Union Formation can be influenced by a number of external factors such as time of exposure of a slope, angle of slope, amount of rainfall, and collection of water in depressions above slope, and by internal factors such as natural physical properties of the rocks and overconsolidation. Upon exposure to air, many of the clay-rich rocks of the Fort Union Formation tend to dessicate and become intensely fractured near the surface of an exposed face. Cracks form on some slopes after only a few months of exposure, and the period of time a slope is required to be stable is an inportant design consideration.

Piping may occur if water collects in surface depressions above a slope, and may cause slumping or flowage of the slope below. Expansion of overconsolidated rocks, particularly denser clay shales, may be a contributive factor in slope failure in rocks of the Fort Union Formation. This possibility needs to be investigated further. 
Slope stability calculations.--Safety factors for a typical openpit design in the Fort Union Formation of the Powder River Basin were calculated by the conventional method of slices; that is, by the formula

$$
F_{s}=\frac{[d N \tan \phi+c d L]}{d T}
$$

where $F_{S}$ is the safety factor which must be greater than 1 for the slope to be stable; $\mathrm{dN}$ and $\mathrm{dT}$ are, respectively, the normal and shear forces acting on each slice; $\phi$ is the angle of internal friction; $c$ is the cohesion; and $d L$ is the length of the slip surface on a slice.

- Summation is from one through the number of slices. Side forces and the effect of forces from seepage were not considered in these calculations. Material properties used for the calculations along with an idealized open-pit cross section are shown in figure 11.

Figure 11.--NEAR HERE

Potential surfaces of failure for which safety factors were calculated are shown in figure 12. The dashed line in the figure

Figure 12.--NEAR HERE

indicates the geometry after removal of a coal bench. Safety factors for both geometries were determined. 


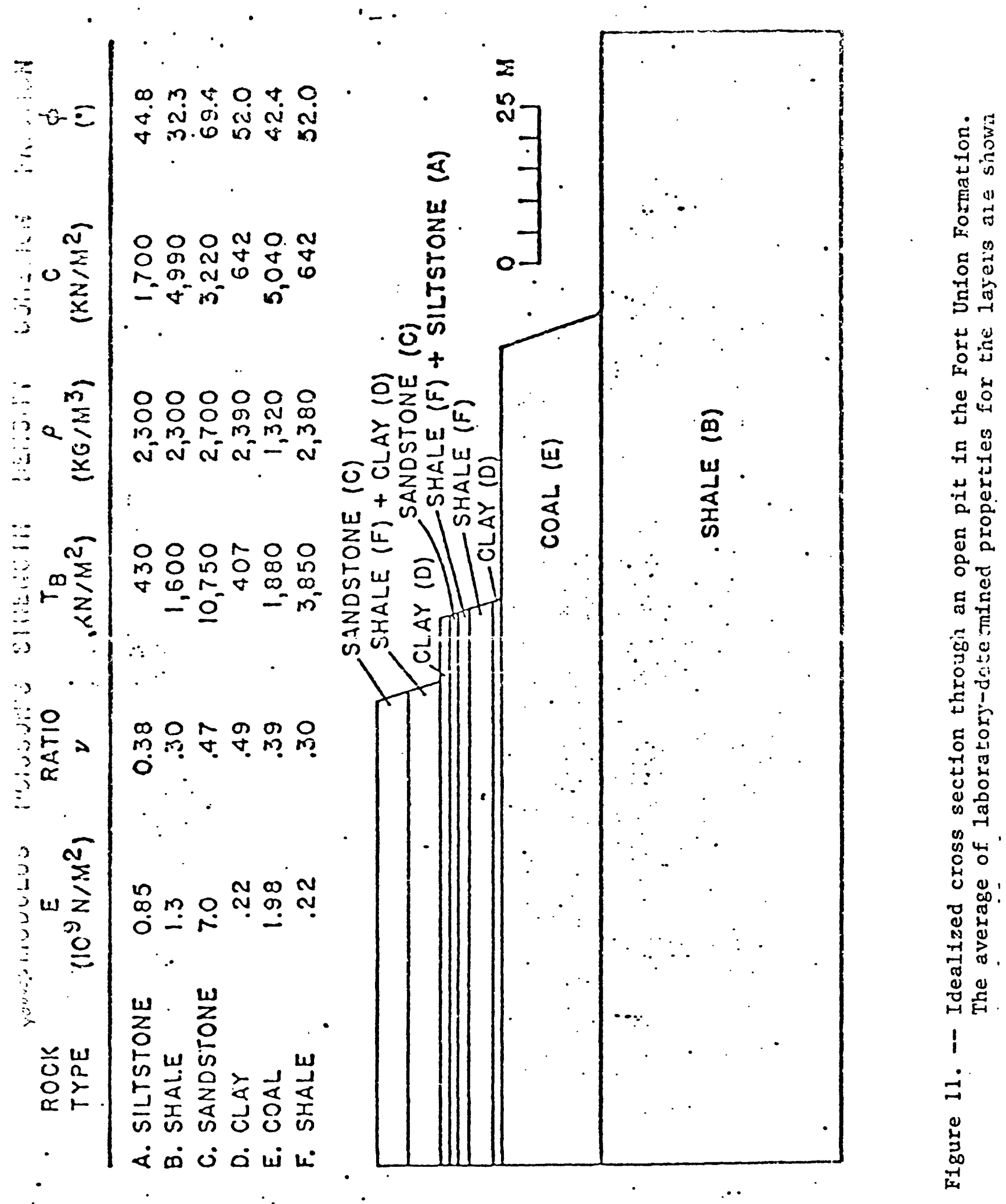




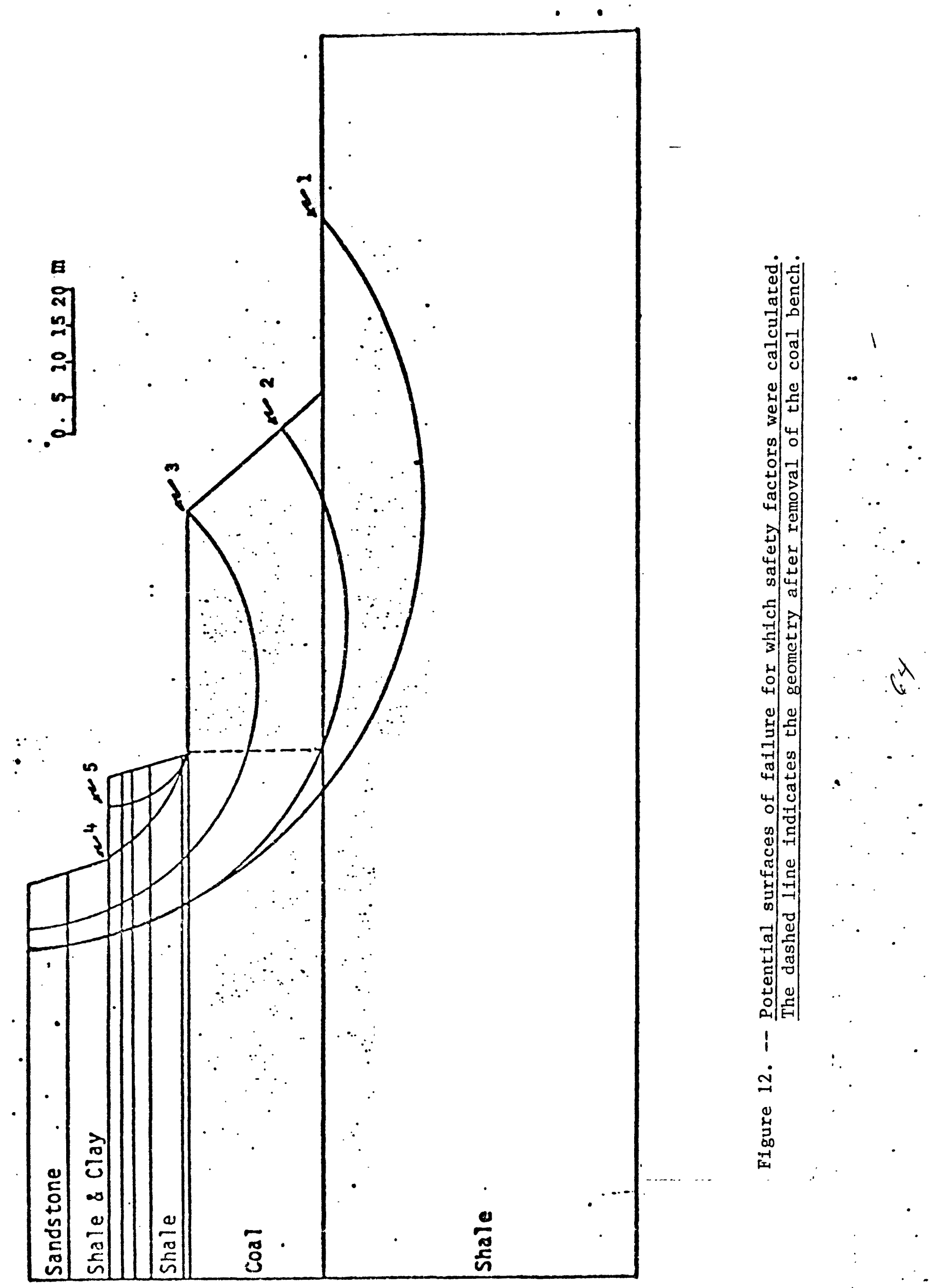


We considered the effects of changing rock properties on the safety factors. Two different cases were considered: the first case is that in which the values for the properties given in figure 11 were used; and in the second case, the cohesion of each layer was reduced to zero. This reduction was made in a rough attempt to account for the effect of fractures in the rock layers on their strength. This reduction of the cohesions to zero should be considered as an extreme case, as the actual cohesions of the rock layers will probably lie somewhere between zero and the laboratory values given in figure 11. Safety factors for the five potential failure surfaces are given in table 8. Note that when the average laboratory values are used

Table 8.-NEAR HERE

(case 1), the safety factors are high for all surfaces--whether the coal bench is present or absent. On the other hand, when the cohesions are zero (case 2), safety factors are drastically reduced and we see that surfaces 2 and 5 are least stable. In fact, surface 2 is seen to be marginally stable when the coal bench is removed. The addition of seepage forces would further reduce the stability, but further study of this problem is needed.

The most critical conditions for slope stability seem to occur with removal of the coal bench, especially along failure surfaces 2 and 5 . Failure along either surface during the final stages of coal-bench removal could endanger miners and mining equipment. 
Table 8. Safety factors calculated by the method of slices for the five potantial iailure surfaces shown in Figure 12

\begin{tabular}{|c|c|c|c|c|}
\hline & \multicolumn{2}{|c|}{$\begin{array}{c}\text { Coal bench } \\
\text { present }\end{array}$} & \multicolumn{2}{|c|}{$\begin{array}{c}\text { Coal bench } \\
\text { absent }\end{array}$} \\
\hline & Case 1 & Case 2 & Case 1 & Case 2 \\
\hline Surface 非1 & 24.28 & 2.21 & 29.55 & 2.07 \\
\hline Surface 非 & 43.10 & 1.53 & 24.84 & 1.09 \\
\hline Surface 非3 & 89.77 & 2.13 & 35.39 & 1.55 \\
\hline Surface 非 & 24.03 & 2.25 & 24.03 & 2.25 \\
\hline Surface \#5 & 25.35 & 1.28 & 25.35 & 1.28 \\
\hline
\end{tabular}


Conclusions.--Open-pit coal mines of the Fort Union Formation that we have examined generally have stable highwalls. The highwalls do deteriorate with time, and small postmining failures commonly are observed. These would not be particularly critical unless the mining were delayed and then resumed after a period of several months. This time-dependent behavior also has implications for reclamation of highwall slopes. In conducting the geotechnical measurements for determining the optimum reclaimed highwall slope angle, the degradation of the strength paramenters with time must be taken into account. Finally, we emphasize the role of water in highwall stability. Seepage and piping from pools that are allowed to collect above the highwall do lead to small failures and during especially wet weather could contribute to failures on surfaces such as 2 or 5 in figure 12 . 


\section{Lands1ides}

$$
\text { by . }
$$

Roger B. Colton

Landslides are not abundant in the western part of North Dakota, but they could be a continuing cause of damage to highways, railroads, industrial operations, and other facilities. Landslide-prone areas and areas of previous landsliding can probably be identified and avoided. Most of the large slump-type landslides in western North Dakota occur along the steep-walled valleys of the Missouri and the Little Missouri Rivers, and many involve till overlying Fort Union Formation. Others are.along the Des Lacs and Heart River valley. Some landslides occur in the Fort Union on slopes below exposed coal seams, probably because of wetting by water seeping from the coal bed aquifer, or on over-steepened slopes cut on mudstone or shale below a protective cap of clinker or sandstone, as on the slopes of high buttes.

Beds of the White River Formation (or Group) form protective caps on Fort Union on the Killdeer Mountains, Sentinel Butte, and HT (Black) Butte, in Slope County, which are almost completely flanked by landslides. The White River Formation there slumps with the Fort Union. Earth flow is a common shallow type of landslide in the unglaciated upland south of the Little Missouri River and probably constitutes the major unstable ground hazard in the region. 


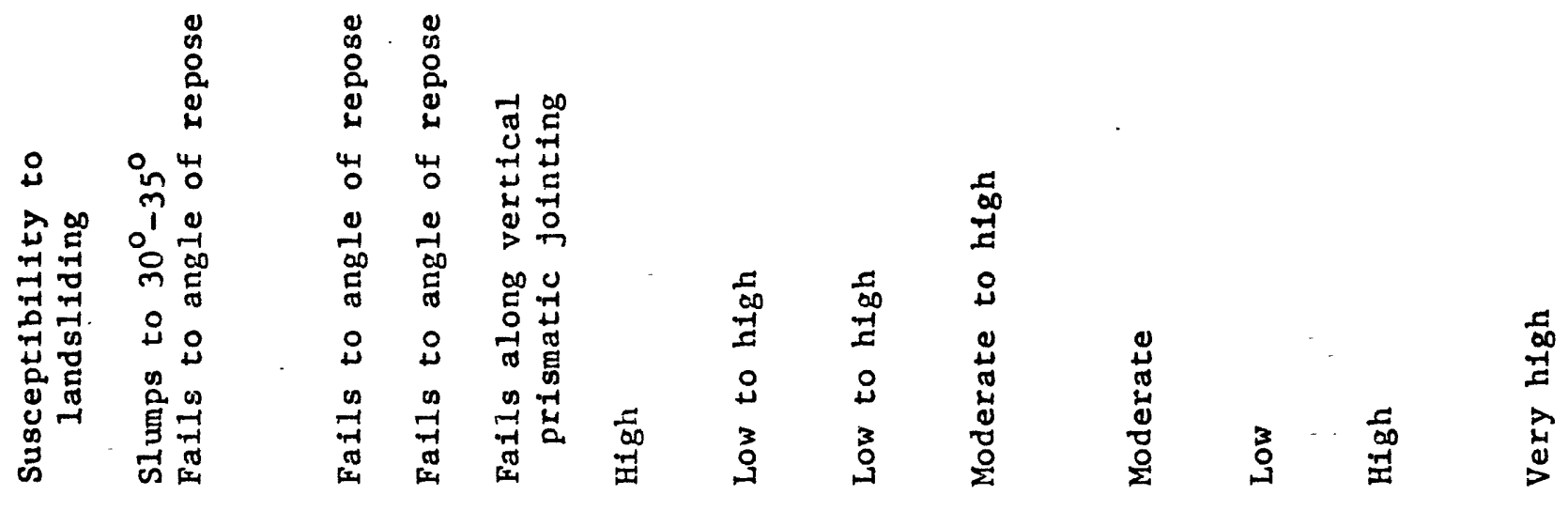

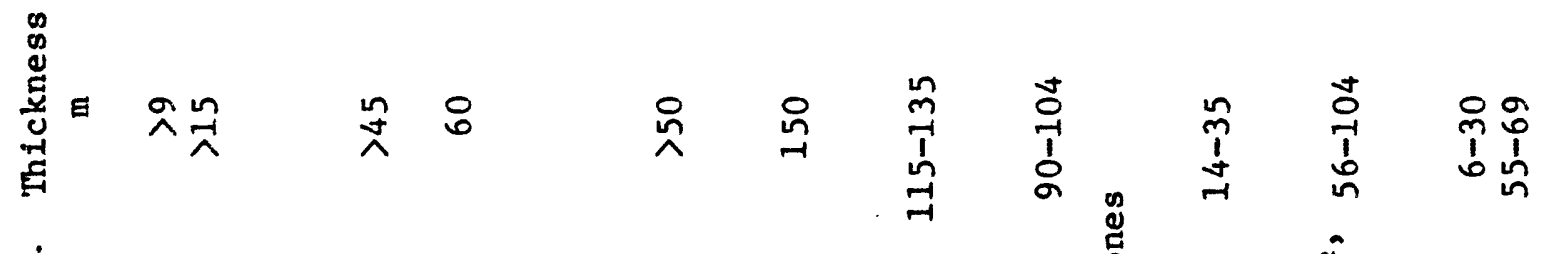

$\stackrel{\leftrightarrow}{\otimes}$

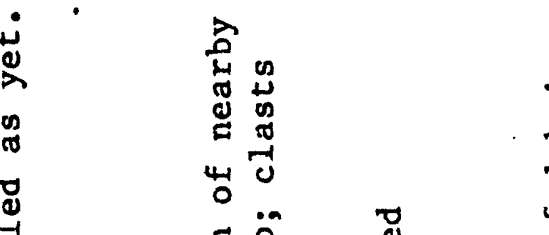

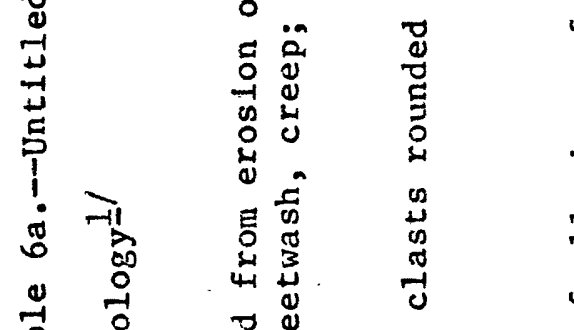

焉

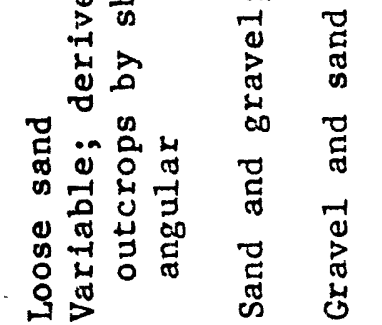

站

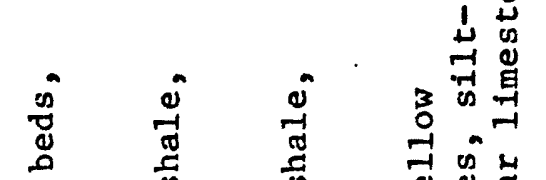

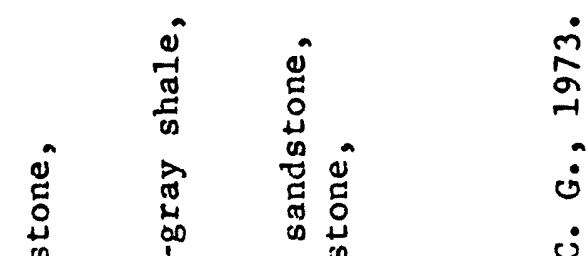

प्山 के के कूष

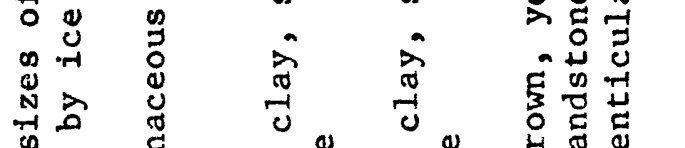

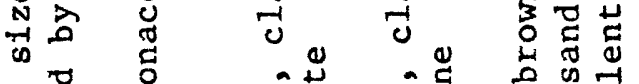

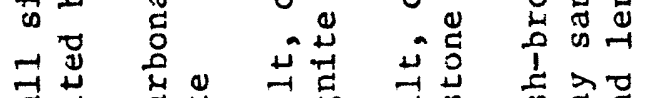

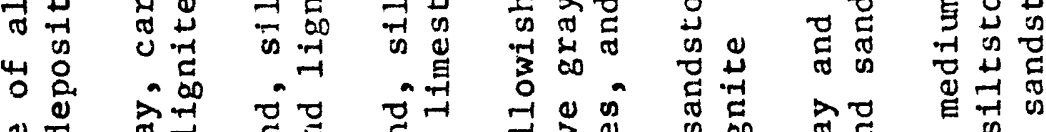

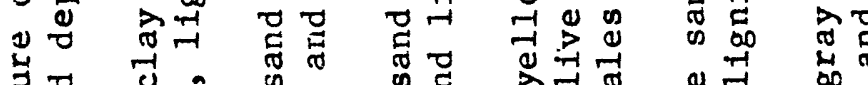

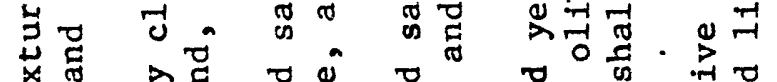

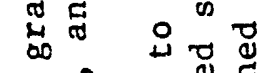

点至

苟 की

范 击 出声 出

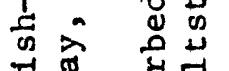

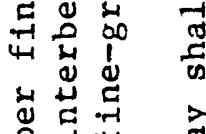

ते न

क्ष

ن

8 


\section{Surface subsidence \\ by}

\section{Richard Dunrud}

Spectacular surface subsidence features that occur in the Fort Union Formation over old underground coal mine workings near Beulah, Haynes, Lehigh, and Wilton, North Dakota are similar to subsidence effects studied recently by the U.S. Geological Survey in the western Powder River Basin. During the first half of this century, coal was mined from the Fort Union Formation in an extensive area of underground workings north of Acme, Wyoming. The surface above the old underground workings now is covered by subsidence depressions that reflect the geometry of the former mine workings. Mining was done by the room-andpillar method, and depressions formed above the old workings where the remaining coal was not strong enough to support the weight of the overburden either because the coal pillars were partially removed or because the initial pillars were too small to support the load over a period of time. The following conclusions drawn from the Acme studies probably are generally applicable, and likely would apply equally well to the North Dakota localities. 
Where the overburden is less than $23 \mathrm{~m}$ ( $5 \mathrm{ft}$ thick), the depressions range in depth from $0.3-2.5 \mathrm{~m} 1-8 \mathrm{ft}$ ) and tend to be rectangular, like the mine workings they overlie. Where the overburden is more than $23 \mathrm{~m}(75 \mathrm{ft}$ ) thick, the depressions tend to be more circular or elliptical. The depressions commonly are slightly larger than the mined-out area. Tension cracks, a few centimeters to a meter or so wide, occur at the margins of the depressions, and compression ridges occur locally in the central parts of the depressions. Locally, soil and colluvium over the tension cracks has stretched without fissuring and conceals the cracks, but, in places, holes as much as $3 \mathrm{~m}$ $(10 \mathrm{ft}$ ) wide have formed in the soil and colluvium over the cracks because of piping, gravity collapse, or the activities of man or animals.

Vertical-walled subsidence pits, 1-3 m (3-10 ft) wide and 3-6 m (10-20 ft) deep, have occurred in time above individual mine openings or above the intersection of two mine openings. Many of these pits occur within subsidence depressions that were formed eariier. The pits were formed by upward stoping initiated by collapse of mine roofs. Collapse of mine roofs commonly is governed by the width of the mine opening, the strength of the mine roof, and the adequacy of the roof support system used. The occurrence of pits, therefore, is dependent on the time required for the roof to collapse, the thickness and strength of the overburden, and the width of the mine opening. Pits may suddenly form with little or no warning, tens or even hundreds of years after mining. 


\section{Coal mine fires \\ by \\ C. Richard Dunrud}

$\because$ Coal mine fires in abandoned mine workings are threats to the environment and to adjacent coal deposits. According to Rabchevsky (unpublished Ph. D. thesis, George Washington University, April 6, 1972, 94 p.) at least 288 coal fires are burning out-of-control in the United States, of which about 70 percent are located in the western states. About 120 fires, or about 42 percent of the national total, are located in the States of Montana, Wyoming, and North Dakota. Studies by the U.S. Geological Survey and by the U.S. Bureau of Mines (D. L. Donner, oral commun., 1975) show that fires in at least three abandoned coal mines are burning out-of-control in a 400-600 hectare (1,000-1,500 acre) near Acme, Wyoming. The coal in these abandoned mine workings apparently was ignited by increased temperatures in the coal resulting from local stress increases and from the introduction of oxygen and water through open subsidence cracks in the overburden. 
The increase in internal energy of the coal produced by the local increased stress levels and by oxidation of the coal and the pyrite in the coal appears to have elevated the temperatures sufficiently to ignite the coal. Field studies indicate that, once the coal ignites, the fire can support combustion and spread by drawing in fresh air through open subsidence cracks and pits in the overburden and exhausting gases via other cracks and pits. The voids created as the coal is burned produce further ground settlement, more tension cracks, and more local pits by a stoping process, which in turn provides more oxygen to the fire. Care must be taken in in-place gassification experiments to insure that subsidence cracks do not form, or controlled fires may suddenly burn out of control.

Fires were observed on old exposed highwalls. To prevent the possibility of fires occurring on final graded highwalls in modern mines, special care must be taken to insure that the highwall is adequately covered with spoil or other noncumbustible material during restoration.

A reconnaissance study of the gases that are exhausted along with steam and smoke through tension cracks and pits was conducted by the U.S. Geological Survey in the Acme mining area, north of the town of Acme, in the spring of 1976. Analyses revealed carbon disulfide, carbon oxysulfide, and an unknown sulfur compound. Methane in excess of one percent by volume was detected in a crack near one of the most intense fire areas. The exhausting gases also contain less nitrogen and more helium than normal atmosphere. 


\section{Seismic risk}

extracted from von Hake, 1975

.. No earthquakes of intensity $V$ or above (Módified Mercalli Scale) have occurred in North Dakota during historic time. The first instrumentally located earthquake in North Dakota occurred on July 8 , 1968, but its intensity did not exceed IV. North Dakota (and the eastern half of Montana) is included in seismic risk zone I where only minor damage is expected. 
ECONOMIC RESOURCES

Lignite

by

Edward J. McKay

.- Lignite occurs in an area of about $72,520 \mathrm{sq} . \mathrm{km} \cdot(28,000 \mathrm{sq} \cdot \mathrm{mi}$.

in the western half of North Dakota (fig. 1) in a sequence of beds about $375 \mathrm{~m}(1,200 \mathrm{ft})$ thick in the Tongue River and Sentinel Butte Members of the Fort Union Formation of Paleocene age. Thicknesses of individual lignite beds vary within individual mines and between mined deposits, but most minable beds average about 2.4 to $3.6 \mathrm{~m}(8-12 \mathrm{ft})$ in thickness, and the Harmon bed is as much as $12 \mathrm{~m}$ (40 ft) thick in the Bowman deposit (North) in Slope County (Pollard and others, 1972). Some individual beds extend over wide areas (Rehbein, 1977). In addition to coal, which may occur in as many as thirteen beds in any one locality, the Fort Union Formation consists of poorly consolidated sandstone and siltstone, and minor amounts of shale. Subordinate amounts of lignite are present in the adjoining Ludlow Member of the formation. 
Estimated resources of lignite in North Dakota total nearly 531 billion tons as shown in several resource categories on table 9. Included in the total is 16 billion tons of lignite in strippable deposits less than $61 \mathrm{~m}$ (200 ft) below the surface (table 10).

Tables 9 and 10.--NEAR HERE

Production in 1975 of 8.5 million tons of 1ignite in North Dakota (U.S. Bur. of Mines Annual Report) is expected to increase to about 30 million tons in 1982 (Metzger, 1976). At that increased level of production the i6 billion tons would last more than 500 years. 
Table 9. Estimated original 1ignite resources of North Dakotal/

[In millions of short tons. Overburden $0-365 \mathrm{~m}(1,200 \mathrm{ft})^{2}$ /. All figures are for lignite in the ground.]

$\begin{array}{ccc}\text { Original } & \begin{array}{l}\text { Inferred re- } \\ \text { reserves } \\ \text { sources and } \\ \text { in the }\end{array} \\ \text { grosources in } \\ \text { beds less than } \\ 1.5 \mathrm{~m}(5 \mathrm{ft}) \\ \text { thick }\end{array}$

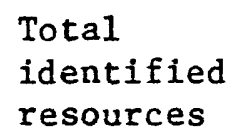

Total identified resources

(1)

Adams
Billings
Bownan
Burke
Burleigh
Divide
Dunn
Golden valley
Grant
Hetinger

\section{McHenry}

McKenzie

McLean

Mercer

Morton

Montrail

Oliver

Renville

Sheridan

slope

Stark

Ward

Williams

\section{6}

2,836

1,136

530

208

792

2,992

1,290

670

1,847

40

3,211

1,923

4,754

1,968

(2)

$(3)=(1)+(2)$

1,857

17,718

7,021

6,610

1,157

8,264

71,042

8,319

4,658

12,653

78

28,972

14,555

24,159

13,282

749

1,923

59

---

4,994

14,629

15,916

724

660

15,097

2, 216

905

2,144

23, 481

9,381

24,791

313,457

Total

37,453

118

32,183

16,478

29,913

15,250

15,378

17,839

783

660

20,091

25,697

10,286

26,935

350,910
Additional hypothetical resources in unmapped and unexplored areas

(4)

$(5)=(3)+(4)$
Total

estimated

resources

$4 / 180,000$

530,910

Cumulative production and losses in mining to Jan. $1,1972^{5}$ /
Resources remaining in the ground, Jan. 1,1972

Resources remaining in the ground, Jan. 1, 1972

..... $\quad 280$

$\overline{530,630}$

1/ From Brant (1953), with minor modification of data for Hettinger County.

2/ About 98 percent of the total lignite in North Dakota is $305 \mathrm{~m}(1,000 \mathrm{ft})$ or less below the surface.

$3 /$ Measured and indicated resources in beds $1.5 \mathrm{~m}(5 \mathrm{ft})$ or more thick.

$4 /$ Not classified by county.

5/ Assuming past losses in mining equal past production. 


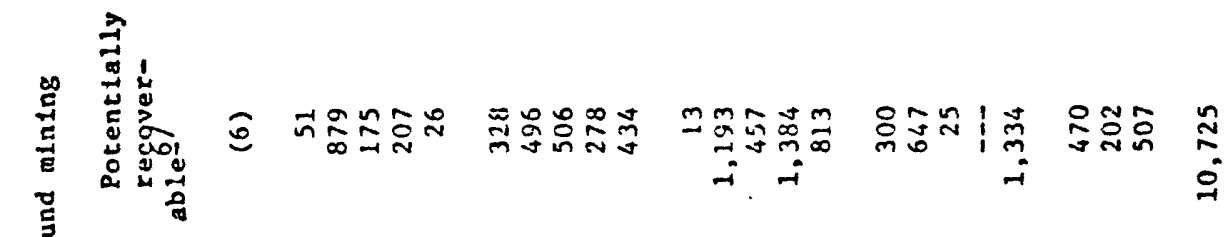

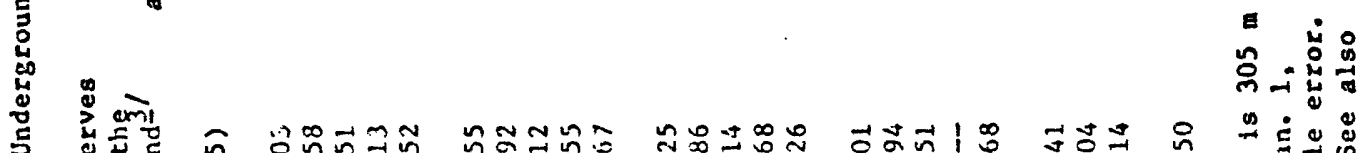

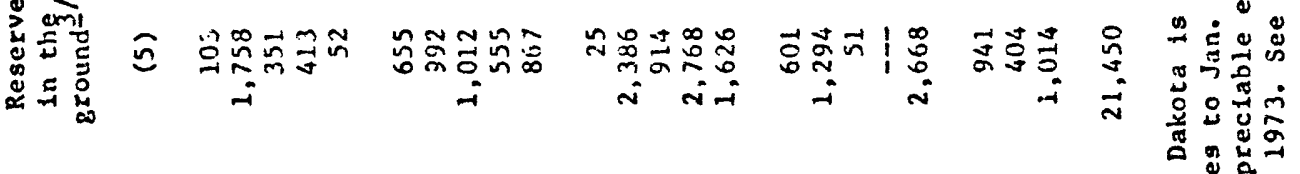
焉

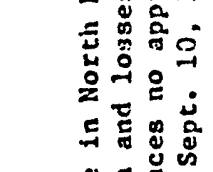

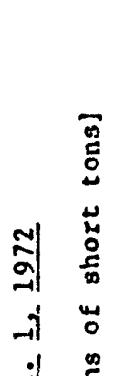
究

$\approx$<smiles>C=CCCCC</smiles>

亗

If

인

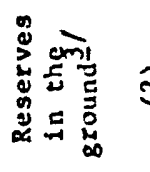

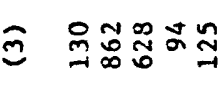

육ำำำ

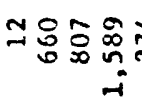

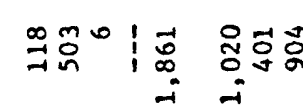

:

过施

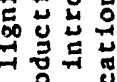

न

象范

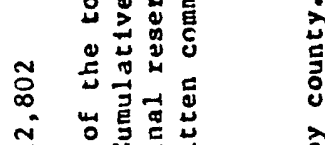

〔

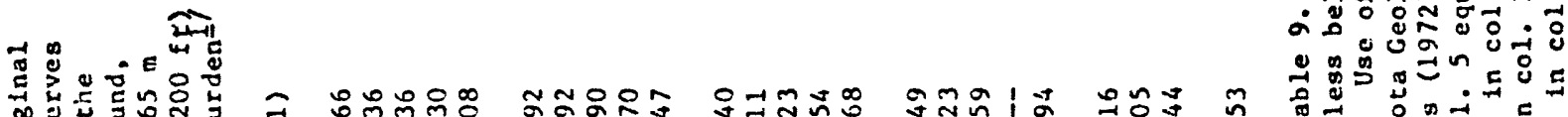

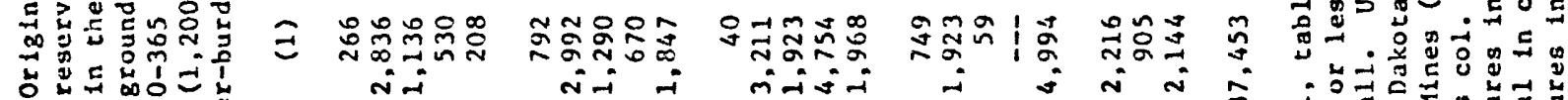

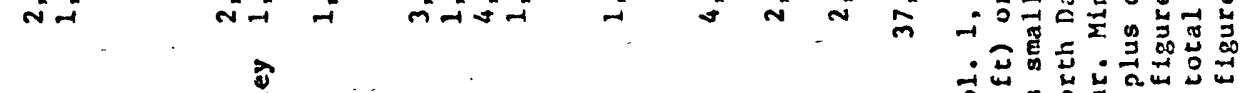

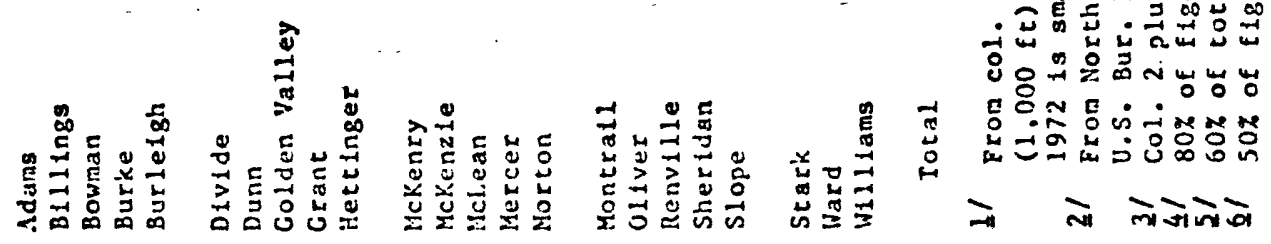


The effects of coal mining on land disruption and water use, and problems of reclamation are discussed in reports of the Northern Great Plains Resource Program (1975). In addition to these reports, the social, economic, and environmental effects of burning lignite within the state are the subject of continuing studies that are sponsored by the U.S. Energy Research and Development Administration and the University of North Dakota.

Lignite chemistry.--The average composition of lignite, according to Fieldner and others (1942), is 36.4 percent moisture, 26.6 percent volatile matter, 30.2 percent fixed carbon, and 0.7 percent sulfur (average BTU is 6,990 ). Average BTU content lignite of the Fort Union Formation in North Dakota, by county, ranges from 6,120 to 7,510 (table 11). Trace elements (less than 0.1 percent or $1,000 \mathrm{ppm}$ ) in samples of coal from the Fort Union Formation total slightly more than 0.1 percent (Hatch and Swanson, 1976). Minor elements (0.1 percent-1 percent or $1,000-10,000 \mathrm{ppm}$ ) and major elements (more than 1 percent or $10,000 \mathrm{ppm}$ ) are the ash-forming constituents of coal. 
Studies such as those by Klein and others (1975) and $0^{\prime}$ Gorman and Walker (1972) on ash and gases resulting from coal combustion in power plants point to the need for quantitative studies of minor and trace elements in combustion products. The pre-combustion chemical properties of lignite, together with some properties obtained from ash, are shown by sample analyses published by the U.S. Bureau of Mines and the U.S. Geological Survey and are taken from the Northern Great Plains Resource Program Report of 1974. The extent to which the quantitative values of eiements and oxides shown in these analyses are duplicated in emissions from individual power plants and captured by boller slag, fly ash, flue gas, scrubbers, and electrostatic precipitators has been studied at one power plant in North Dakota by the Radian Corporation (1975), and wider aspects of the subject are dealt with by Klein and others, (1975). In particular, metals that are regarded as dangerous when in excess, such as arsenic, lead, mercury, and selenium, should be monitored (Baria, 1975). 
Among the factors of economic concern to operators of power plants are the amounts of ash, sulfur, sodium, iron, and calcium in lignite, and the amounts and form of hydrogen, which largely determine the feasibility of using lignite for gasification and liquifaction purposes. Average analyses of samples taken in 21 counties of North Dakota by the Bureau of Mines are shown in tables 11 and 12. Trace element composition is shown in table 13 and major oxide composition of the ash in table 14. The most complete and current bibliography of work in this field is contained in U.S. Geological Survey (1976b).

Tables 11, 12, 13, and 14.--NEAR HERE 
Table 11." "Average analys 1s of coal by councy and bed

n. County $\rightarrow$ Bed

Mótsture Ash Sulfur

North Dakota

A.R. 1ll A.R. 2ll: bry

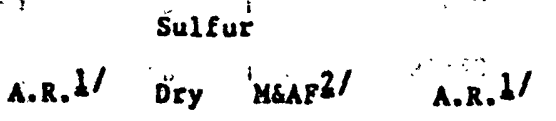

Beu

No. of

$\frac{\text { Adains }}{\text { Uncorrelated }}$

33.1

10.5

County tota:

33.1

10.5

15.7

$\begin{array}{llll}1.2 & 1.8 & 2.2 & 7.080\end{array}$

B11 $11 \ln 89$

Uncorrelated

County total

38.5

$6.2 \div 10.1$

$\begin{array}{llll}1.2 & 1.8 & 2,1 & -7,080\end{array}$

38.5

6.210 .1

$\begin{array}{llll}.8 & 1.4 & 1.5 & 6,350\end{array}$

Bownan

Uncortelated

County total

"43:4

6.611

43.4

6.611 .7

Burke

Uncortelated

County total

$33: 4$

1.911

1.911

Burlelah

Uncorrelated

County total

33.4

6

$\begin{array}{lllllll}35.1 & 6.2 & 9.7 & .6 & 1.0 & 1.1 & 1.100\end{array}$

Divise

Uncorrelated

County tocal

35.1

6.29.

32.0

$7.8 \quad 11.6$

$.7 \quad .6$

32.0

$7.8 \quad 11.6$

.4

Dunn

Uncorrelated

County total

40.6

$7.0 \quad 11.9$

40.7

$7.0 \quad 11$

Golden Valley

Uncorrelated

County cotal

s.

41.3

5.8

Grant

41.3

5.89 .9

34.5

$10.4 \quad 15.9$

County total

34.5

$10.4 \quad 15$

Hetringer

Cowney toeel

IICKenzie

elated

County total

Melean

County totel

6.410

Mercer

Uncorrelated

County total

33.8

6.810.

Morton

Uncorrelated

County totel

39.0 : 8.0

Mountrall

Uncorrelated

County total

$$
3.6
$$

$\begin{array}{llll} & .2 & .6 & .4 \\ .2 & .2 & .4 & .4\end{array}$

6,640

6,640

ollver

Uncorrelated

County totes

36.5

10.3

36.5

10.3

Renville

Uncortelated

County tote$$
6.3
$$

35.2

$6.3 \cdot 9.8$

42.5

6.311.

County totel

42.5

6.3

$41.1 \quad 8.5 \quad 14.6$

$\frac{\text { Stark }}{\text { Uncorrelated }}$

County total.

Ward

$\frac{\text { Ward }}{\text { Uncorrelated }}$

- County total

HLLlams

Uncorrelated

county total

state total

$$
41.1
$$$$
\text { 8.5 }
$$

37.2

$\begin{array}{lllllll}5.5 & 8.8 & .1 & .3 & .3 & 6,790\end{array}$

$\begin{array}{lllll}5.5 & 8.8 & .1 & .3 & .3\end{array}$

6,790

$41.0=6.3=10.8 \quad .5 \quad .961 .0$

41.0

6.310 .8

$35.1 \quad \ldots 6.8 \quad 10.5$

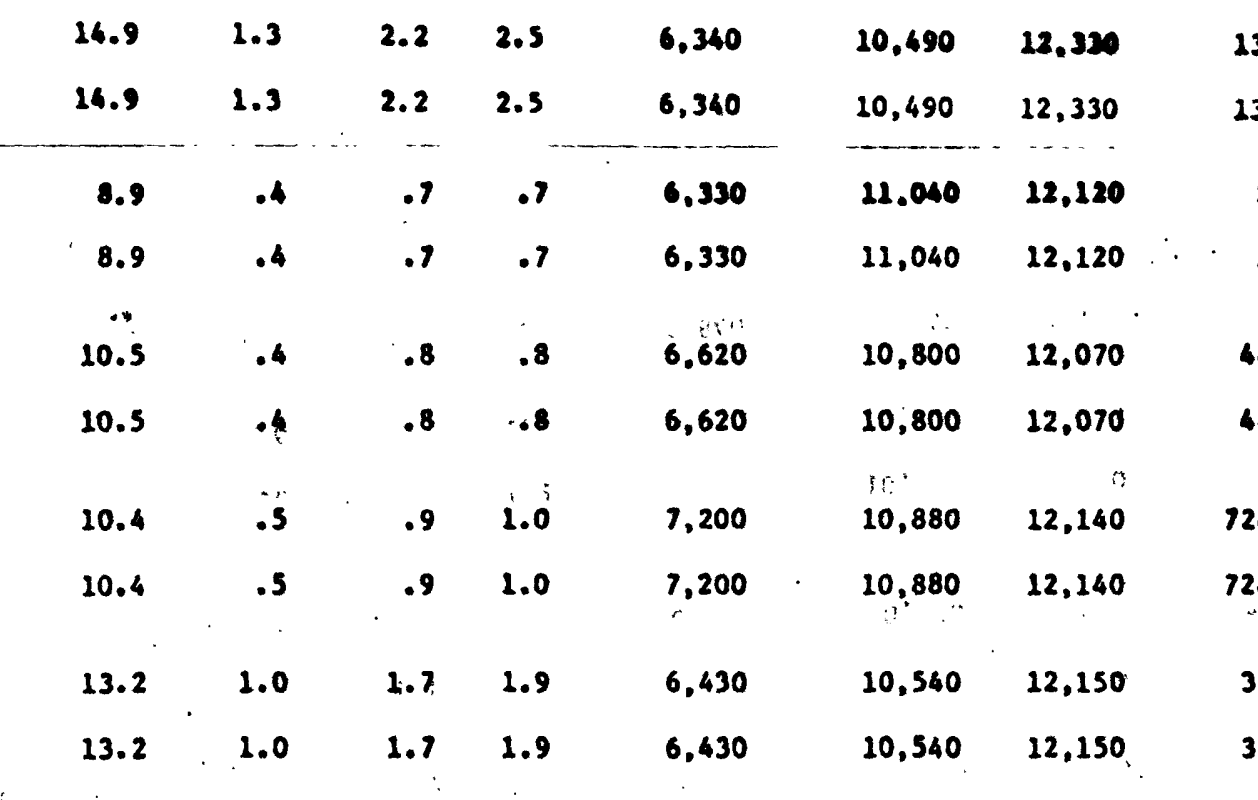

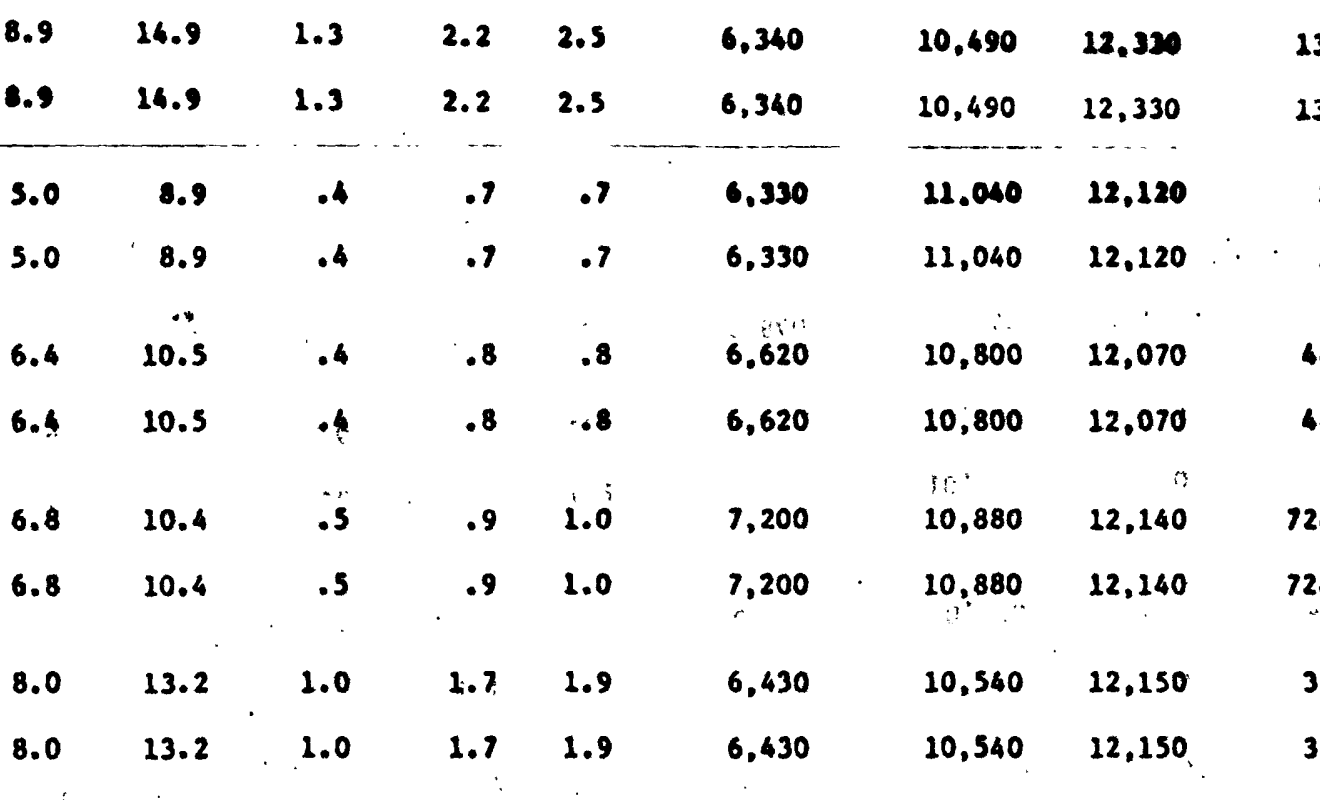

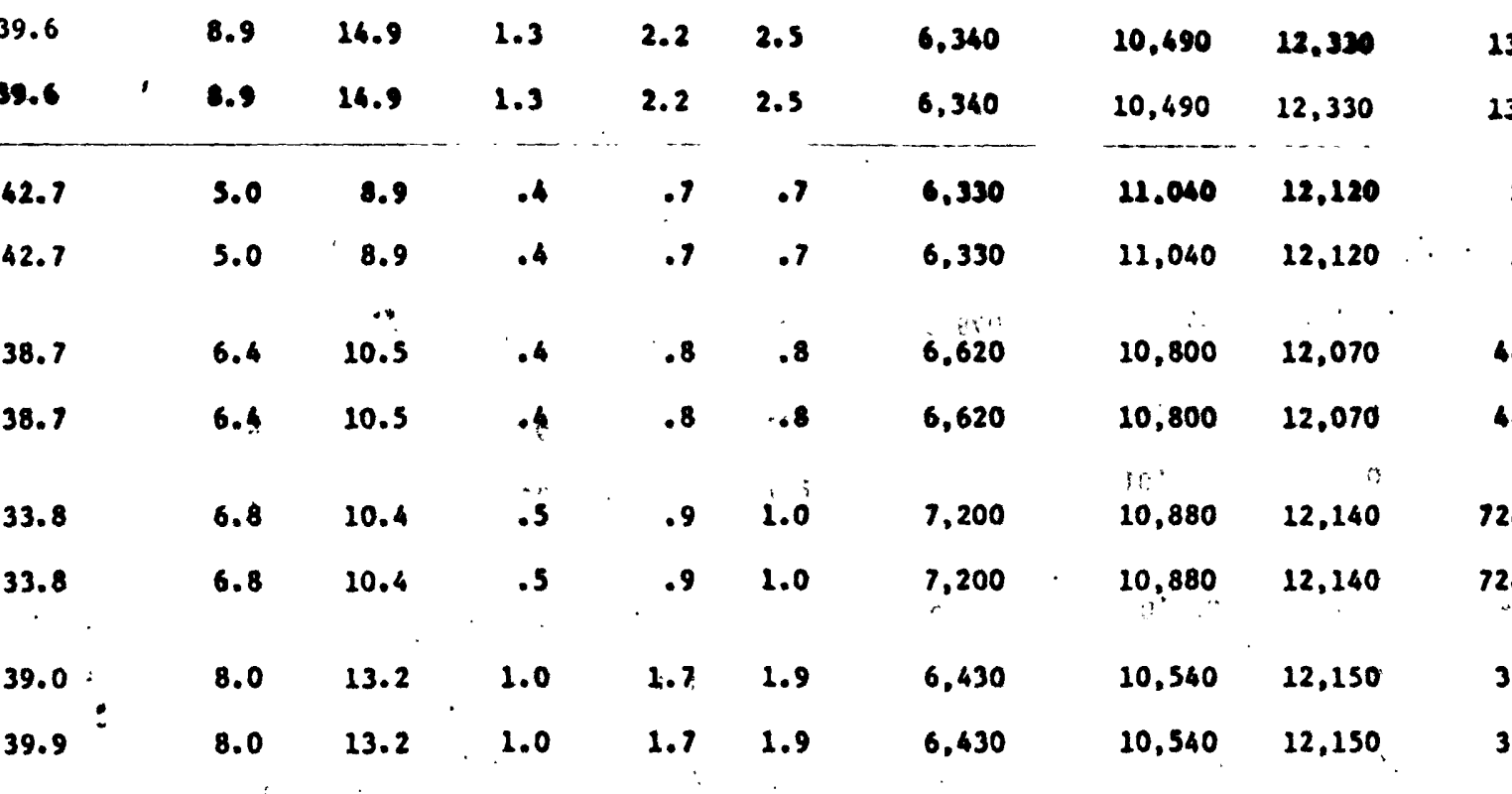

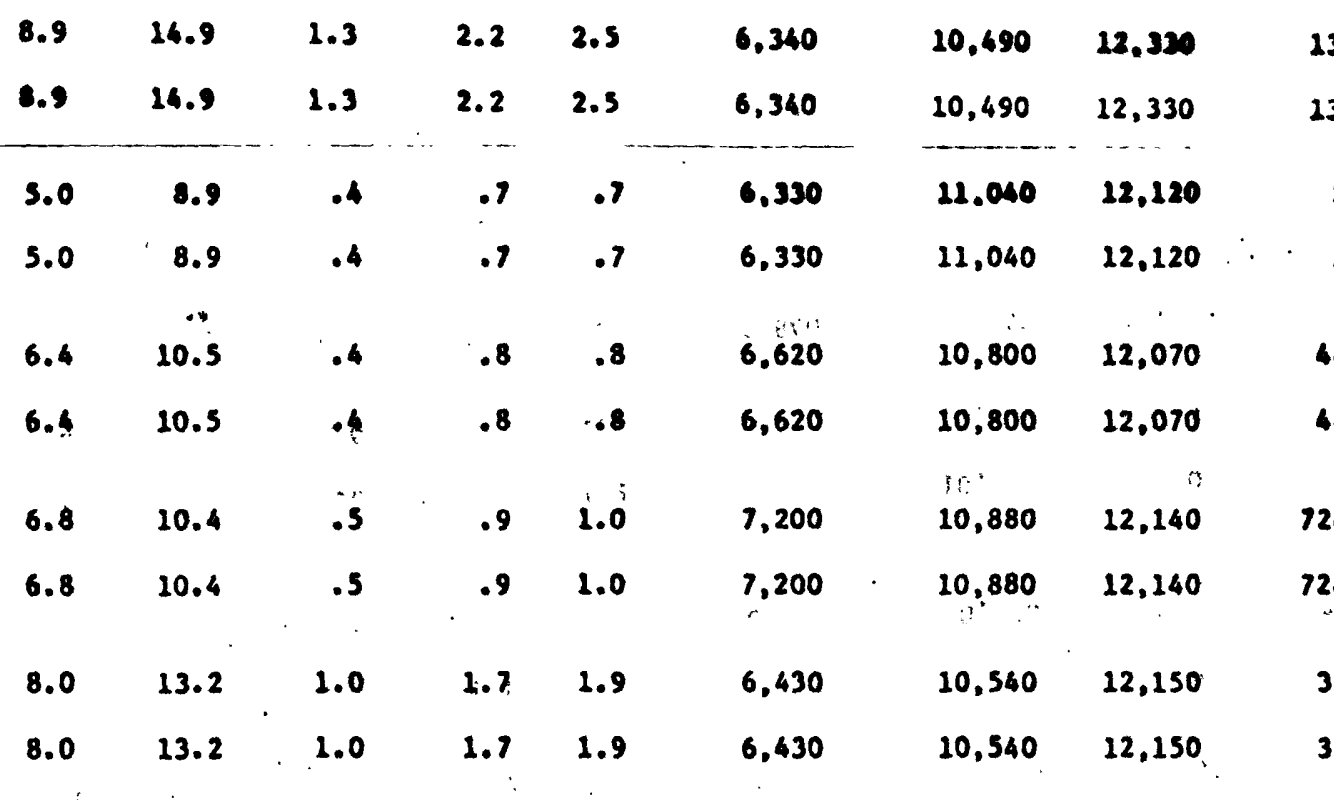

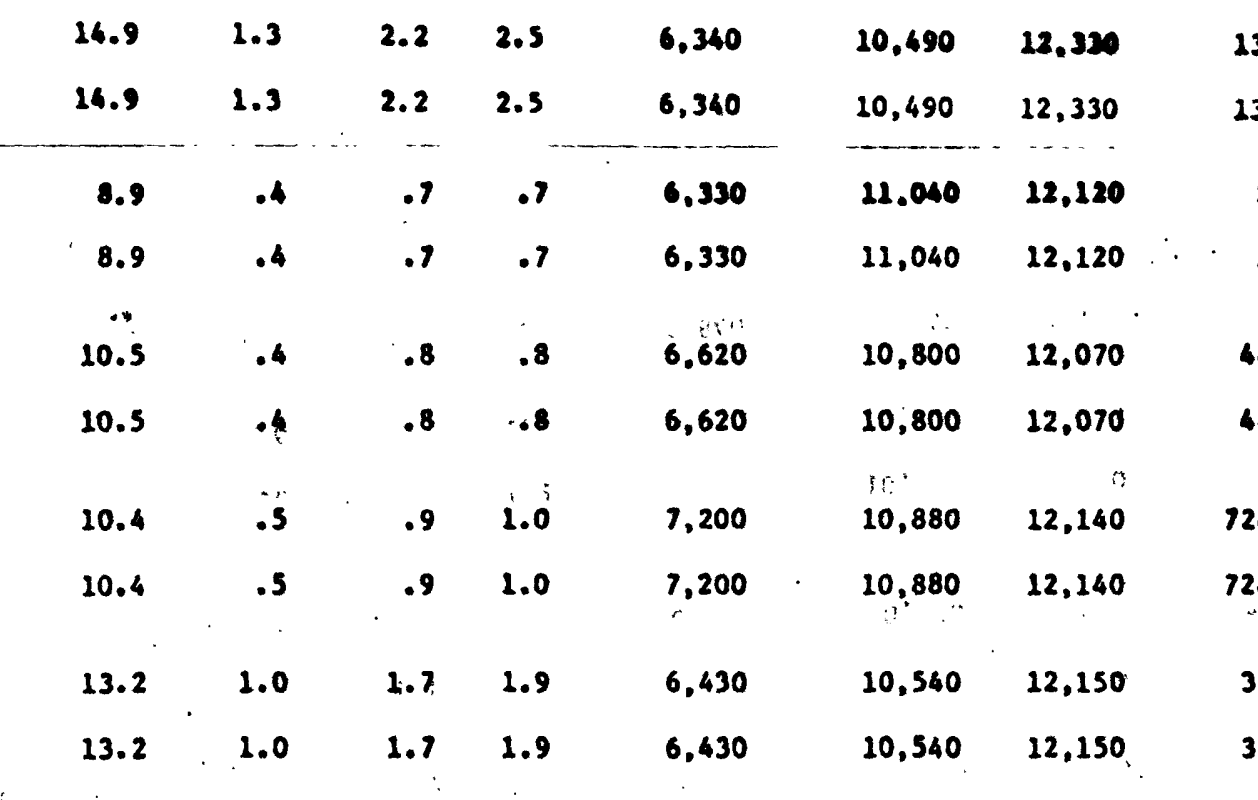

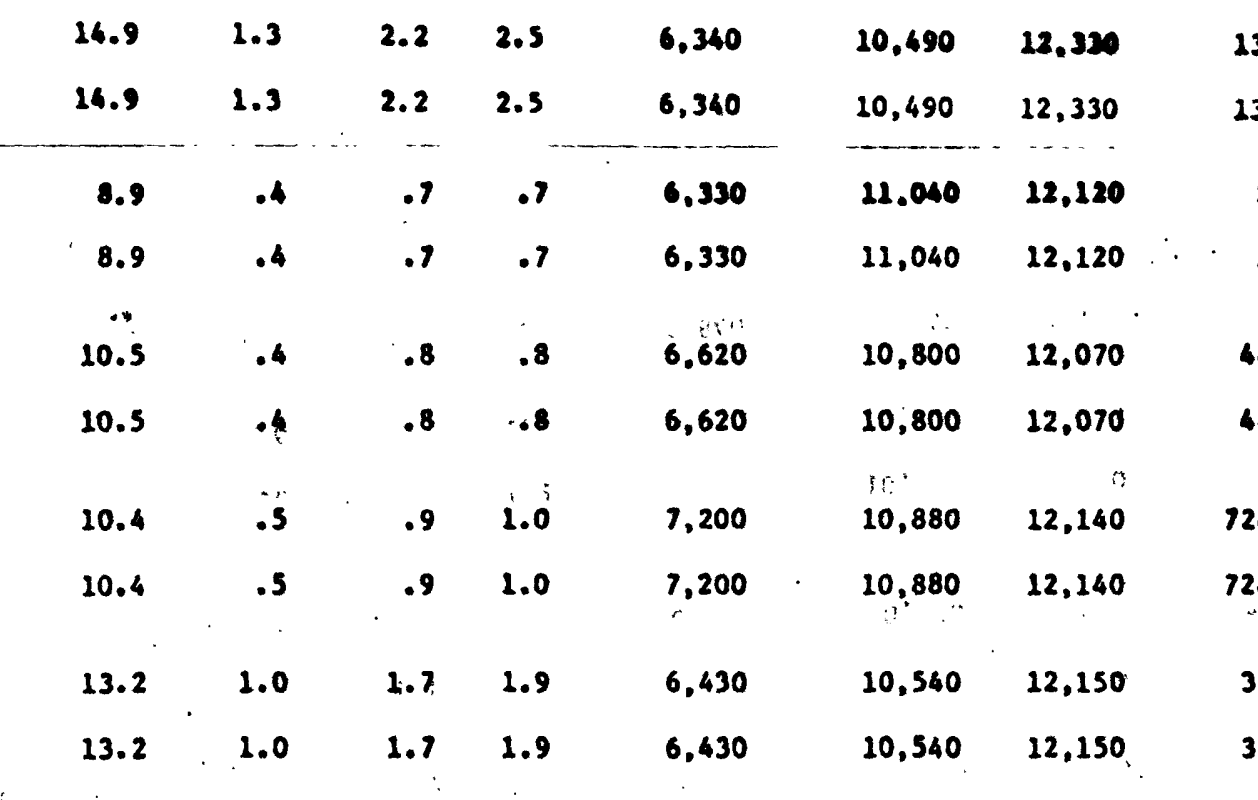

$\begin{array}{llll}.5 & .9 & 1.0 & 6,420\end{array}$

$.4 \quad .7 \quad 1,050$

"Dey is Markl anal.

?

(n)

16

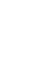

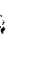

5


Table 12. Proximate, ultimate, Btu, and sulfur analyses of 31 samplés of 1ignite from western №rth Dakota

IAll analyses, except Btu in percent; original molsture content may be slightly more than shown because samples were collected and transported In plastic bags to avoid metal contamination; Ar, as received, and iAF, molsture and ash frec; ( $T$ ) and (B) indicate top and bottom of bed, respectively. $\mathrm{All}$ analyses of mine samples by Coal Analysis Section, U.S. Bureau of Mines, Pittsburgh, Pennsylvania.l

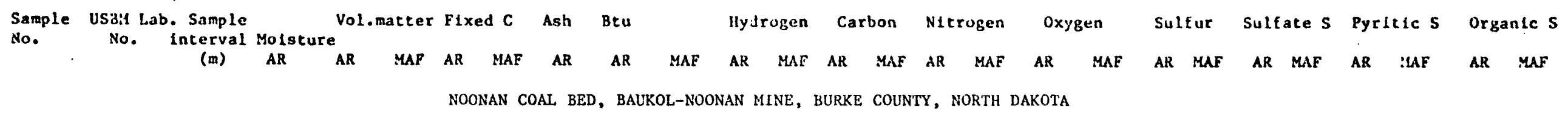

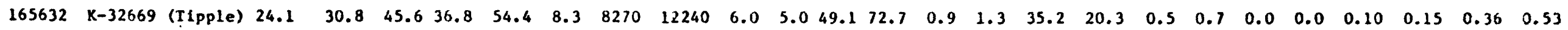
COTEAU BED, VELVA STRIP MINE, WARD COUNTY, NORTH DAKOTA

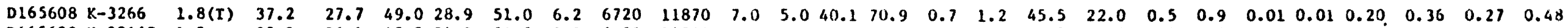

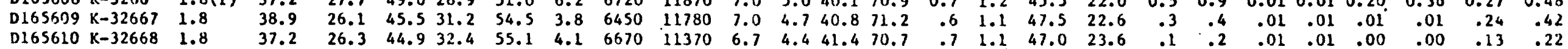
KUTHER (K) AND HAGEL (H), GLEN HAROLD MTNE, MERCER COUNTY, NORTH DAKOTA

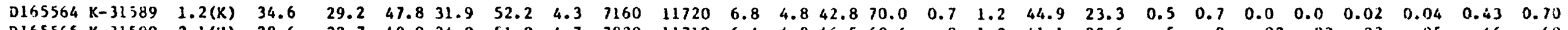

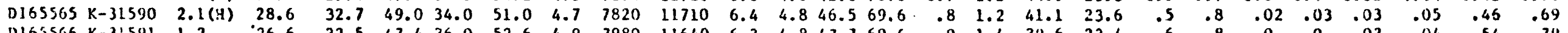

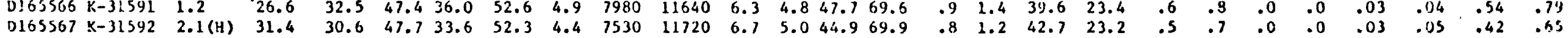
BEULAI BED, INDIAN HEAD MHE, MERCER COUNTY, NORTH DAKOTA

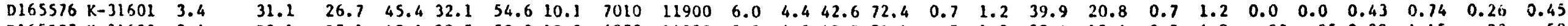

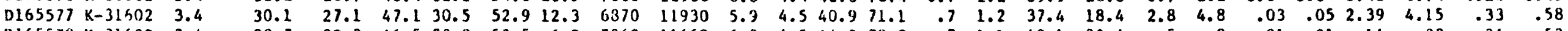

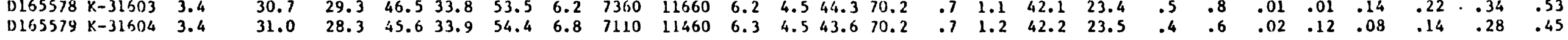
BEULAH BED, SOUTH BEULAH MINE, MERCER COUNTY, NORTH DAKOTA

D155572 K-31597 2.4 D165573 K-31598 . D] $65574 \times-31599 \quad 2.4$ D165575 K-31600

D165568 $:-31593 \quad 3.0$ D165569 $:-31596 \quad 3.0$ $\begin{array}{lll}D ! 55570 & K-31575 & 3.0 \\ \text { D165571 } & \mathrm{K}-31596 & \mathbf{3 . 0}\end{array}$

$3165976 \quad \mathrm{~K}-34014 \quad 1.2$ (1st seam)
$\mathrm{K}-340751.2$ (r. 2nd seam) D165780 K-34076 1.2 ( $B$, 2nd seam) $016082 \quad \mathrm{~K}-34,077 \quad 1.2$ (1st seam)

$0165935 \mathrm{~K}-360781.2$ (T, 3rd seam) $165986 \mathrm{~K}-34079 \quad 1.2$ (B, 3 r.l sean)
$0.25939 k-3403 j \quad 1.2$ (T, 2and sean) D165990 $K-34081 \quad 1.2$ (B, 2nd seam) (1sy sedin)

$0165993 \cdot k-34083 \quad 2.1$ (1st seain)

$\begin{array}{llllllllllllllllllllllll}29.8 & 29.1 & 47.3 & 32.4 & 52.7 & 8.7 & 7250 & 11800 & 6.3 & 4.8 & 42.4 & 69.0 & 0.5 & 0.8 & 39.9 & 21.8 & 2.2 & 3.6 & 0.05 & 0.08 & 1.84 & 3.00 & 0.33 & 0.56\end{array}$

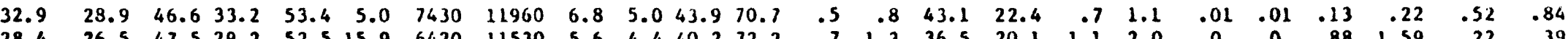

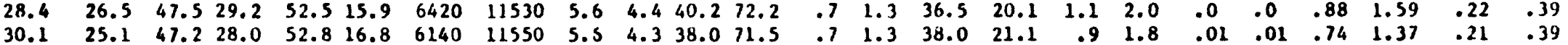

HAGEL BED, CENTER (BAUKOL-NOONAN) MINE, OLIVER COUNTY, NORTH DAKOTA

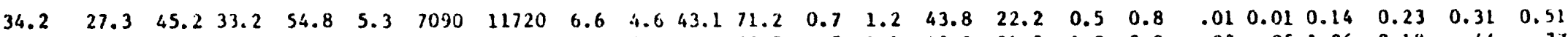

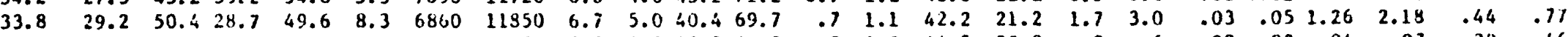

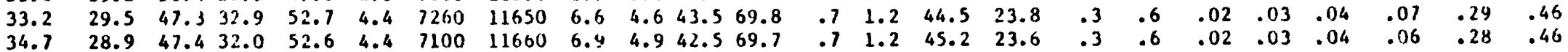
HARMON BED, GASCOYNE (PEERLESS) MINE, BOWNAN COUNTY, NORTH DAKOTA

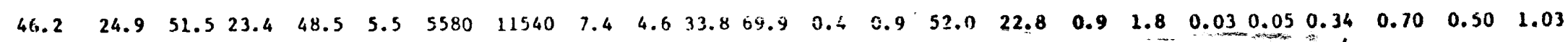
$\begin{array}{llllllllllllllllllllllll}37.5 & 30.1 & 55.2 & 24.3 & 44.8 & 8.1 & 6760 & 12410 & 7.2 & 5.6 & 39.3 & 72.2 & .6 & 1.0 & 43.8 & 19.4 & 1.0 & 1.8 & .01 & .01 & .50 & .92 & .50 & .91\end{array}$ $\begin{array}{llllllllllllllllllllllll}42.2 & 25.5 & 49.6 & 25.9 & 50.4 & 6.4 & 6180 & 12040 & 7.3 & 5.1 & 36.6 & 71.4 & .4 & .9 & 48.7 & 21.5 & .6 & 1.1 & .06 & .11 & .06 & .11 & .46 & .90\end{array}$ $\begin{array}{lllllllllllllllllllllllll}44.6 & 24.4 & 47.5 & 27.0 & 52.5 & 4.0 & 6090 & 11870 & 1.5 & 5.0 & 36.3 & 70.7 & .5 & 1.0 & 51.0 & 21.9 & .7 & 1.4 & .00 & .00 & .05 & .10 & .67 & 1.30\end{array}$ $\begin{array}{llllllllllllllllllllllllll}45.0 & 24.4 & 48.3 & 26.2 & 51.7 & 4.4 & 6010 & 11880 & 7.5 & 4.9 & 35.6 & 70.5 & .5 & 1.0 & 51.3 & 22.1 & .7 & 1.5 & .00 & .00 & .05 & .09 & .70 & 1.33\end{array}$ $\begin{array}{lllllllllllllllllllllllll}42.3 & 25.0 & 49.6 & 25.6 & 50.4 & 7.1 & 6080 & 12030 & 7.3 & 5.2 & 35.6 & 70.5 & .4 & .9 & 47.8 & 19.8 & 1.8 & 3.6 & .01 & .01 & .11 & .22 & 1.70 & 3.37\end{array}$

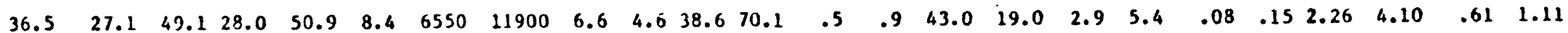
$\begin{array}{lllllllllllllllllllllllll}42.7 & 27.0 & 52.9 & 24.1 & 47.1 & 6.2 & 6320 & 12350 & 7.5 & 5.3 & 36.7 & 71.7 & .5 & 1.0 & 48.2 & 20.2 & .9 & 1.8 & .01 & .01 & .11 & .21 & .82 & 1.60\end{array}$

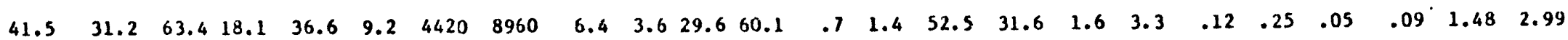

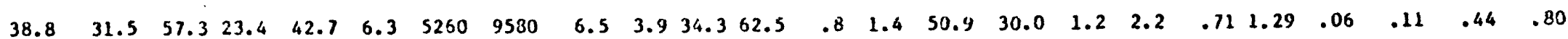

-1/Leonardite (weathered coal, largely soluble in alkaline solution). 


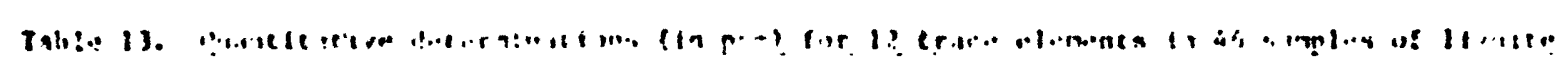

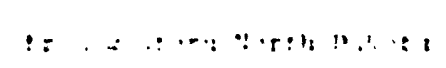

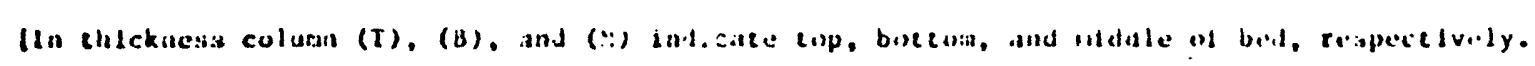

Values for $\mathrm{Cd}, \mathrm{Cu}, \mathrm{L1}, \mathrm{Pb}$, and $\mathrm{Zn}$ are calculated fron analysess on ash of ciral.)

$$
\begin{aligned}
& \begin{array}{l}
\text { Sample } \\
\text { No. }
\end{array} \begin{array}{l}
\text { Thickness } \\
\text { of sample } \\
\text { Interval } \\
\text { (m) }
\end{array} \\
& \text { NOONAN BED, BAUKOL-HOONAN MINE, BURKE COUNTY, NORTH DAKOTA }
\end{aligned}
$$

$\begin{array}{lllllllllllllll}\text { D165632 (Tripple) } & 8 & 0.1 & 10.9 & 70 & 0.09 & 3.8 & 4.3 & 1.0 & 0.5 & <2.0 & 1.0 & 5.8 & 10.7\end{array}$ COTEAU BED, VELVA MINE, WARD COUNTY, NORTH DAKOTA

$\begin{array}{lrrrrrrrrrrrrrr}\text { D165605 } & 1.8 & 4 & <0.1 & 3.4 & 40 & 0.09 & 1.5 & 2.1 & 0.2 & 0.5 & <2.0 & 1.4 & 3.2 & 6.86 \\ 0165606 & 1.8 & 5 & <.1 & 4.7 & 20 & .07 & 2.0 & 2.0 & .2 & .4 & <2.0 & .8 & 2.3 & 6.76 \\ \text { D165607 } & 1.8 & 10 & <.1 & 8.0 & <20 & .23 & 7.0 & 3.0 & .3 & 1.0 & 3.3 & 1.8 & 2.6 & 10.0 \\ \text { D165609 } & 1.8 & 10 & <.1 & 11.6 & 35 & .17 & 7.2 & 4.2 & .5 & 1.3 & 4.3 & 2.6 & 2.5 & 10.5 \\ \text { D165609 } & 1.8 & 5 & <.1 & 3.4 & 30 & .08 & 1.5 & 2.0 & .1 & .3 & <2.0 & .1 & 1.8 & 6.80 \\ 0165610 & 1.8 & 4 & <.1 & 3.4 & 35 & .15 & 1.4 & 2.2 & .1 & .3 & <2.0 & .3 & 1.8 & 7.38 \\ \text { D165611 } & 1.8 & 4 & <.1 & 4.3 & <20 & .07 & 4.2 & 2.5 & .2 & .5 & <2.0 & <.1 & 2.0 & 8.34 \\ 0165612 & 1.8 & 4 & <.1 & 4.0 & 20 & .10 & 2.5 & 2.3 & .2 & .5 & 2.8 & .5 & 1.7 & 7.64 \\ 0165613 & 1.8 & 5 & <.1 & 5.7 & 30 & .25 & 4.3 & 3.3 & .2 & .8 & 3.8 & 1.3 & 1.5 & 8.34\end{array}$

KUTHER (X) AND HAGEL $(H)$ BEDS, GLENHAROLD MINE, MERCER COUNTY, NORTH DAKOTA

$\begin{array}{lrrrrrrrrrrrrrr}01655564 & 1.2 & 10 & <0.1 & 3.4 & <20 & 0.10 & 1 . & <1.5 & 0.2 & 0.7 & 9.4 & 2.1 & 1.4 & 7.02 \\ 0165565 & 2.1 & 5 & <.1 & 6.4 & <20 & .09 & 1.2 & <1.5 & .7 & .8 & <2.0 & 1.1 & 2.2 & 7.16 \\ 0165566 & 1.2 & 15 & <.1 & 3.6 & <20 & .08 & .6 & 2.0 & .4 & .8 & <2.0 & .6 & 1.3 & 6.52 \\ 0165567 & 2.1 & 5 & <.1 & 2.4 & <20 & .05 & .5 & <1.5 & 3.0 & .5 & <2.0 & .6 & 2.3 & 5.78\end{array}$

BEULAH BED, INDIAN HEAD MINE, MERCER COUNTY, NORTH DAKOTA

$\begin{array}{rrrrrrrrrrrrrrr}0165576 & 3.4 & 4 & <0.1 & 7.5 & <20 & 0.05 & 3.4 & 4.8 & 0.3 & 0.5 & 3.4 & 0.9 & 1.5 & 9.58 \\ 0165577 & 3.4 & 10<.1 & 10.6 & <20 & .07 & 3.8 & 5.3 & 1.4 & .8 & 4.0 & 1.9 & 9.1 & 10.6 \\ 0165578 & 3.4 & 10<.1 & 5.6 & <20 & .034 & 2.1 & 3.1 & .4 & .9 & 5.2 & .7 & 2.1 & 10.4\end{array}$

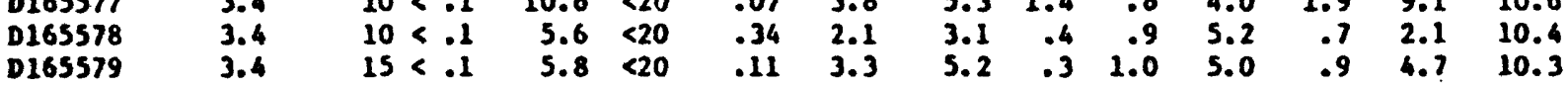

BEULAH BED, SOUTH BEULAH MINE, MERCER COUNTY, NORTH DAKOTA

\begin{tabular}{|c|c|c|c|c|c|c|c|c|c|c|c|c|c|}
\hline $\begin{array}{l}D 165568 \\
D 165569 \\
D 165570 \\
D 165571\end{array}$ & $\begin{array}{l}3.0 \\
3.0 \\
3.0 \\
3.0\end{array}$ & $\begin{array}{rl}10 & <0.1 \\
8 & <.1 \\
5 & .1 \\
5 & <.1\end{array}$ & $\begin{array}{l}3.2 \\
6.8 \\
2.8 \\
4.3\end{array}$ & $\begin{array}{r}20 \\
30 \\
<20 \\
<20\end{array}$ & $\begin{array}{l}0.22 \\
.11 \\
.05 \\
.05\end{array}$ & $\begin{array}{l}0.9 \\
1.5 \\
.9 \\
.9\end{array}$ & $\begin{array}{r}<1.5 \\
4.7 \\
1.6 \\
2.5\end{array}$ & $\begin{array}{r}0.1 \\
.5 \\
.3 \\
.3\end{array}$ & $\begin{array}{l}1.0 \\
1.3 \\
1.6 \\
.7\end{array}$ & $\begin{array}{r}<2.0 \\
3.7 \\
<2.0 \\
<2.0\end{array}$ & $\begin{array}{r}0.5 \\
1.5 \\
.8 \\
.7\end{array}$ & $\begin{array}{l}2.2 \\
1.7 \\
1.6 \\
1.3\end{array}$ & $\begin{array}{c}10.8 \\
9.94 \\
6.48 \\
6.28\end{array}$ \\
\hline
\end{tabular}

$\begin{array}{lrrrrrrrrrrrrr}D 165572 & 2.4 & 30<0.1 & 4.7 & <20 & 0.21 & 1.8 & 3.1 & 0.5 & 0.6 & <2.0 & 0.7 & 27.7 & 10.2 \\ 0165573 & 0.9 & 10<.1 & 3.2 & <20 & .19 & .7 & <1.5 & .2 & .6 & 2.5 & .4 & 3.5 & 6.58 \\ 0165574 & 2.4 & 5<.1 & 7.3 & 20 & .10 & 7.6 & 7.6 & 1.1 & 1.2 & 5.5 & 1.6 & 5.4 & 19.1 \\ 0165575 & 0.9 & 8<.1 & 11.3 & 50 & .10 & 9.9 & 7.0 & 1.0 & 1.5 & 5.6 & 2.2 & 15.0 & 23.5\end{array}$

\begin{tabular}{|c|c|c|c|c|c|c|c|c|c|c|c|c|c|}
\hline D165974 & $\begin{array}{l}1.2 \\
\text { ind seam) }\end{array}$ & $1<0.1$ & 7.5 & 40 & 0.08 & 8.1 & 6.8 & 0.2 & 1.0 & - & -- & 15.8 & 11.3 \\
\hline D165975 & $\begin{array}{l}1.2 \\
\text { seam) }\end{array}$ & $2<.1$ & 4.2 & $<20$ & .05 & 2.5 & 2.2 & .2 & .4 & $-\infty$ & $\cdots$ & 6.1 & 6.14 \\
\hline D165976 & $\begin{array}{c}1.2 \\
\text { seam) }\end{array}$ & $4<.1$ & 3.3 & 30 & .15 & $<1$. & $<1.5$ & .2 & .5 & $-\infty$ & $\cdots$ & 2.1 & 11.8 \\
\hline D165977 & $\begin{array}{c}1.2 \\
\text { seam) }\end{array}$ & $4<.1$ & 2.3 & $<20$ & .12 & 1. & 1.8 & .2 & .4 & -- & -- & 1.5 & 7.30 \\
\hline D165978 & $\begin{array}{l}1.2 \\
\text { 2nd seam) }\end{array}$ & $1<.1$ & 6.7 & $<20$ & .14 & 3.1 & 3.1 & .2 & .8 & $\cdots$ & $\cdots$ & 1.9 & 7.74 \\
\hline D165979 & $\begin{array}{c}1.2 \\
\text { 2nd seam) }\end{array}$ & $5<.1$ & 8.1 & $<20$ & .48 & 7.5 & 5.1 & .5 & 1.2 & -- & $\cdots$ & $<1.5$ & 11.3 \\
\hline D165980 & $\begin{array}{c}1.2 \\
\text { 2nid seam) }\end{array}$ & $2<.1$ & 4.2 & 20 & .37 & 2.1 & 4.2 & .2 & .7 & $\cdots$ & $\cdots$ & $<1.5$ & 10.4 \\
\hline D165981 & $\begin{array}{l}1.2 \\
\text { 2nd seam) }\end{array}$ & $1<.1$ & 3.6 & $<20$ & .07 & 2.1 & 2.7 & .1 & .2 & - & - & $<1.5$ & 7.42 \\
\hline D165982, & $\begin{array}{c}1.2 \\
\text { seam) }\end{array}$ & $10<.1$ & 2.9 & $<20$ & .09 & $<1$. & 2.6 & .1 & .4 & - & $\cdots$ & $<1.5$ & 6.40 \\
\hline D165983 & $\begin{array}{c}1.2 \\
\text { seasi }\end{array}$ & $2<.1$ & 3.7 & $<20$ & .06 & 1. & 3.2 & .1 & .4 & -- & -- & $<1.5$ & 8.04 \\
\hline D2C5384 & $\begin{array}{c}1.2 \\
3 \mathrm{rd} \text { seam) }\end{array}$ & .1 & 4 & $<20$ & .40 & 4.9 & 3.9 & .2 & .9 & $-\infty$ & $\cdots$ & $<1.5$ & 8.64 \\
\hline 0165985 & 3rd seam) & $<.1$ & 4.7 & 20 & .09 & 3.8 & 3.3 & .5 & $2^{6}$ & $\cdots$ & $\cdots$ & $<1.5$ & 7.38 \\
\hline D165986 & $\begin{array}{c}1.2 \\
\text { 3rd seam) }\end{array}$ & $5<.1$ & 3.3 & $<20$ & .42 & 3.6 & 4.6 & .4 & .5 & $\cdots$ & $\cdots$ & $<1.5$ & 10.3 \\
\hline D165987 & $\begin{array}{c}1.2 \\
3 \mathrm{rd} \text { sean) }\end{array}$ & $1<.1$ & 15.4 & $<20$ & .12 & 18.7 & 11.1 & .4 & 1.1 & -- & $\cdots$ & 3.0 & 11.7 \\
\hline D165989, & $\begin{array}{c}1.2 \\
\text { 2nd } \operatorname{sen}(\mathrm{a})\end{array}$ & $2<.1$ & 7.1 & 70 & .31 & 5.2 & 1.5 & .2 & .8 & -- & -- & $<1.5$ & 11.4 \\
\hline D165989. & $\begin{array}{c}1.2 \\
\text { 2nd senm) }\end{array}$ & .1 & 4.4 & $<20$ & .60 & 2.1 & $<1.5$ & .4 & .9 & -- & $\cdots$ & $<1.5$ & 20.4 \\
\hline D255990 & $\begin{array}{c}1.2 \\
2 n d \text { seam) }\end{array}$ & $2<.1$ & 5.0 & 30 & .31 & 4.63 & $<1.5$ & .4 & .8 & -- & $\cdots$ & $<1.5$ & 10.7 \\
\hline 01659.31 & $\frac{1.2}{2 n d \text { sean) }}$ & $2<. i$ & 6.3 & 200 & .20 & 4.4 & 4. & is & 1.0 & $\cdots$ & $\cdots$ & $<1.5$ & 8.24 \\
\hline $\begin{array}{c}0165992^{2} \\
\ldots \ldots\end{array}$ & Seliva) & 2 & 3.1 & $<20$ & .11 & 2.7 & 3.6 & .2 & .6 & $-\cdots$ & $\cdots$ & 3.1 & .1 \\
\hline $93^{1}$ & 2.1 & $y<.1$ & 4.1 & $<20$ & .11 & 4.1 & $<1.5$ & - & $2 \cdot 5$ & $\cdots$ & $\cdots$ & 1.5 & .84 \\
\hline
\end{tabular}

HAGEL BED, CENTER (BAUKOL-NOONAY) MINE, OLIVER COUNTY, NORTH.DAKOTA

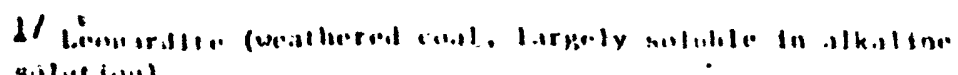
sintint (i.ni). 
Table 14. Yajor oxide composition, tn percents of the laboratory ash

of 46 sanpies of 11gnite frug yustern north Dakuta

(In sample interval column ( $I),(B)$, and $(M)$ Indicate top, bottom, and middle, cespectively.)

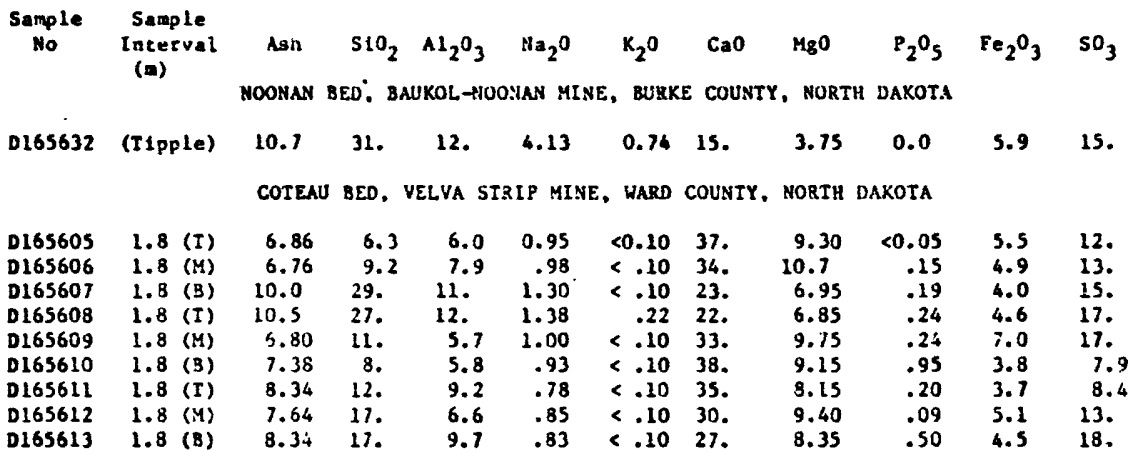

WUTHEK (K) AND HAGEL (H) BEDS, GLENHAROLD MINE, MERCER COUNTY, NORTH DAKOTA

$\begin{array}{lllllllllllll}D 165564 & 1.2 & (\mathrm{~K}) & 7.02 & 13 . & 2.9 & 8.30 & <0.10 & 26 . & 5.60 & <0.05 & 4.3 & 20 . \\ 01655565 & 2.1 & \text { (R) } & 7.16 & 19 . & 6.8 & 9.95 & <.10 & 23 . & 4.90 & .05 & 5.0 & 19 . \\ 01655566 & 1.2 & \text { (K) } & 6.52 & 6.8 & 4.9 & 10.4 & .20 & 27 . & 5.40 & <.05 & 4.4 & 24 . \\ 0165567 & 3.0 & (\mathrm{~K}) & 5.78 & 12 . & 4.7 & 9.20 & <.10 & 28 . & 4.90 & <.05 & 5.4 & 23 .\end{array}$

BEULAH BED, INDLAN HEAD MINE, MERCER COUNTY, NORTH DAKOTA

$\begin{array}{rrrrrrrrrrrr}\text { D165576 } & 3.4 & 9.48 & 34 . & 11 . & 3.50 & <0.10 & 22 . & 6.00 & .91 & 3.0 & : 2 . \\ 0165517 & 3.4 & 10.6 & 26 . & 11 . & 3.80 & .15 & 18 . & 5.25 & .26 & 7.9 & 22 . \\ 0165578 & 3.4 & 10.4 & 16 . & 8 . & 3.25 & <.10 & 17 . & 4.70 & .11 & 15 . & 30 . \\ \text { D165579 } & 3.4 & 10.3 & 27 . & 11 . & 3.55 & <.10 & 19 . & 5.25 & .58 & 1.4 & 20 .\end{array}$

BEULAH BED, SOUTH BEULAH, MERCER COUNTY, NORTH DAKOTA

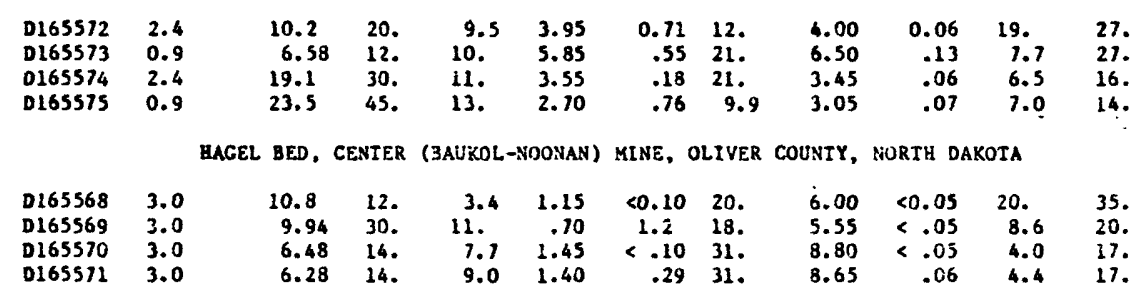

MARMON BED, GASCOYNE (PEERLESS) STKIP MINE, BOUMAN COUNTY, NORTH DAKOTA

\begin{tabular}{|c|c|c|c|c|c|c|c|c|c|c|c|}
\hline $\begin{array}{r}\text { D165974 } \\
\text { (T, }\end{array}$ & $\begin{array}{l}1.2 \\
\text { 2nd seam) }\end{array}$ & 11.3 & 34. & 19. & 1.65 & $<0.10$ & 19. & 7.80 & $<0.05$ & 1.1 & 14. \\
\hline $\begin{array}{l}\text { D165915 } \\
\text { (1st }\end{array}$ & $\begin{array}{l}1.2 \\
\text { seant }\end{array}$ & 6.14 & 1.3 & 9.8 & .50 & $<.10$ & 29. & 9.10 & .06 & 3.6 & 35. \\
\hline $\begin{array}{r}0165916 \\
\text { (1st }\end{array}$ & $\begin{array}{l}1.2 \\
\text { sean) }\end{array}$ & 11.8 & 6.1 & 3.1 & .25 & $<.10$ & 25. & 5.90 & .01 & 20. & 38. \\
\hline $\begin{array}{l}\text { D1659)7 } \\
\text { (1st }\end{array}$ & $\begin{array}{l}1.2 \\
\text { sean) }\end{array}$ & 7.30 & 4.9 & 4.8 & 2.65 & $<.10$ & 26. & 8.40 & .10 & 14. & 39. \\
\hline $\begin{array}{r}D 165978 \\
\text { (I, }\end{array}$ & $\begin{array}{l}1.2 \\
2 \text { nd seam) }\end{array}$ & 7.74 & 29. & 11. & 1.05 & $<.10$ & 23. & 8.30 & $<.05$ & .89 & 24. \\
\hline $\begin{array}{r}0165979 \\
\text { (T. }\end{array}$ & 2.2 & 11.3 & 17. & 10. & .50 & $<.10$ & 19. & 7.80 & $<.05$ & 12. & 32. \\
\hline $\begin{array}{r}\text { D165980 } \\
\text { (B. }\end{array}$ & $\begin{array}{l}1.2 \\
2 \text { nd sean) }\end{array}$ & 10.4 & 11. & 6.3 & .45 & $<.10$ & 21. & 7.10 & .01 & 15. & 37. \\
\hline $\begin{array}{r}\text { D165981 } \\
\text { (B, }\end{array}$ & $\begin{array}{l}1.2 \\
2 \text { nd seam) }\end{array}$ & 7.42 & 14. & 9.6 & .50 & $<.10$ & 32. & 11.1 & .05 & 1.5 & 28. \\
\hline D165982 & $\begin{array}{l}1,2 \\
\text { seam) }\end{array}$ & 6.40 & 2.0 & 6.7 & 1.20 & $<.10$ & 29. & 7.80 & $<.05$ & 11. & 20. \\
\hline $\begin{array}{l}\text { D155983 } \\
\text { (1st }\end{array}$ & $\begin{array}{l}1.2 \\
\text { seam) }\end{array}$ & 8.04 & 2.9 & 4.7 & 1.55 & $<.10$ & 30. & 9.47 & .34 & 9.5 & 33. \\
\hline $\begin{array}{r}\text { D165984 } \\
\text { (I. }\end{array}$ & $3 \mathrm{rd} \mathrm{seam)}^{1.2}$ & 8.64 & 8.5 & 12. & 2.40 & $<.10$ & 23. & 8.00 & .33 & 9.1 & 22. \\
\hline $\begin{array}{r}0165985 \\
\text { (T, }\end{array}$ & $\begin{array}{l}1.2 \\
3 r d \text { seam) }\end{array}$ & 7.38 & 6.2 & 12. & 2.95 & $<.10$ & 27. & 10.0 & .12 & 2.0 & 24. \\
\hline $\begin{array}{r}0165996 \\
\text { (8, }\end{array}$ & $\frac{1.2}{\left.3 \mathrm{rd}^{4} \mathrm{seam}\right)}$ & 10.3 & 8.5 & 9.4 & 2,25 & $<.10$ & 21. & 1.30 & .05 & 15. & 17. \\
\hline $\begin{array}{r}0165987 \\
\text { (8, }\end{array}$ & ${ }_{3 r d}^{1.2}$ seam) & 11.7 & 29. & 19. & 1.65 & $<.10$ & 21 & 6.90 & $<.05$ & .12 & 17. \\
\hline $\begin{array}{r}0165988 \\
\text { (T, }\end{array}$ & $\begin{array}{l}1.2 \\
\text { 2nd seat }\end{array}$ & 11.4 & 30. & 7.7 & 1.95 & $<.10$ & 21. & 7.10 & .36 & 5.2 & 34. \\
\hline $\begin{array}{r}\text { D155989 } \\
\text { (T, }\end{array}$ & $\begin{array}{l}1.2 \\
\text { 2nd se.an) }\end{array}$ & 10.4 & 15. & 5.4 & 2.95 & $<.10$ & 20. & 7.10 & .08 & 18. & 27. \\
\hline $\begin{array}{r}01659 \%, \\
\text { (8, }\end{array}$ & 2nd seam) & 10.0 & 15. & 7.2 & 2.20 & $<.10$ & 23. & 8.30 & .30 & 9.5 & 34. \\
\hline $\begin{array}{c}0155991 \\
\text { (B. }\end{array}$ & $\begin{array}{l}1.2 \\
\text { 2nd seam) }\end{array}$ & 8.24 & 6.4 & 10. & 3.90 & $<: 10$ & 29. & 10.3 & $<.05$ & 3.1 & 36. \\
\hline $\begin{array}{r}0165972^{2} \\
(1 \mathrm{gt}\end{array}$ & $\begin{array}{l}2.1 \\
\text { se..nas }\end{array}$ & 12.1 & 2.8 & 5.3 & 2.00 & $<.10$ & 23. & 7.70 & .06 & 14. & is. \\
\hline $\begin{array}{r}01659930 \\
\text { (1st }\end{array}$ & $\begin{array}{c}2.1 \\
2(x+3)\end{array}$ & $8.8 \%$ & 4.5 & 6.4 & 2.65 & & 24. & {$[1] .6$} & $<.05$ & 6.8 & 16. \\
\hline
\end{tabular}

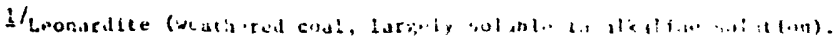


011 and gas

by

Charles W. Spencer

Figure 7 shows the present-day subsurface structural configuration of the North Dakota portion of the Williston Basin as mapped on the base of the Mississippian. Sandberg (1962) provides a regional stratigraphic and paleotectonic framework for the Williston Basin and Ashmore (1971) presents an overview of the petroleum geology of North Dakota. Phanerozoic rocks range in thickness from more than 4,570 m (15,000 ft), in the deeper parts of the basin, to less than $305 \mathrm{~m}(1,000 \mathrm{ft})$ in eastern North Dakota. Lignite deposits overlie those parts of western North Dakota having the greatest potential for petroleum and nearly all the present oil and gas fields are within this area. Consequently, any major development of the lignite resources will have to be interrelated with petroleum exploration and development.

$0 i 1$ was first discovered in North Dakota as recently as April, 1951 (Carlson and others, 1960, p. 124). Subsequently 444,290,885 barrels of oil have been produced through July 1, 1975 (North Dakota Geological Survey, 1976). Most of this oil came from about 2,500 producing we11s drilled in 15 western counties. At the end of 1967, North Dakota ranked 13 th in the United States in proved reserves and annual production (Ashmore, 1971, p. 692). As of July 1, 1976, a total of 5,578 producing wells and dry holes had been drilled in North Dakota, primarily in the area of the lignite fields. 
Oil fields in western North Dakota produce from a variety of structural, structural-stratigraphic, and stratigraphic traps. The diverse nature of traps is exemplified by the Red Wing Creek field which produces oil from Mississippian rocks in an astrobleme (Sawatzky, 1975) caused by the impact of a cosmic body during Jurassic(?) time. Figure 13 shows the location of all oil and gas fields in North Dakota

Figure 13.--NEAR HERE

and adjacent Montana and South Dakota. Early petroleum exploration in the lignite fields area emphasized surface structural mapping. However, it was soon found that, with few exceptions, surface structure did not accurately portray the structural attitude of Mississippian and older rocks. Beginning in the mid 1950's, deep structurally controlled oil pools were located by seisnic methods. However, mapping of subsurface porosity and facies, using well control, is the chief means of locating Mississippian stratigraphic traps that produce oil in the northeast corner of the lignite fields area. These studies greatly reduce the need for seismic exploration. 
Relation of petroleum reservoirs to tectonic features.--The major structural features of the Williston Basin in western North Dakota are shown in figure 14. Two major anticlines are present in the area, the

Figure 14.--NEAR HERE

south-plunging Nesson Anticline and the southeast end of the northwestplunging Cedar Creek Anticline. Both of these anticlines are paleostructural features that had mild structural movement as early as Ordovician time. Muc'l of the Cedar Creek Anticline is bounded by a high-angle reverse fault on the southwest flank, which dies out in Upper Cretaceous shales. Only minor faults are associated with the Nesson Anticline and the subsidiary southeast plunging Sannish Anticline. An extension of the Brockton-Froid fault zone is present in Montana in the northwest part of the map area. This fault may be a right-lateral wrench fault according to Stone (1970, pl. 1).

The Williston Basin has been an intracratonic basin since at least Ordovician time. At times it was connected by seaways to geosynclines to the west or north, or both. Carbonate reservoir rocks were deposited in the basin at least from ordovician through Mississippian time, but marine deposits during Late Jurassic through early Tertiary time were mostly shale and sandstone. The paleomovement on the Cedar Creek, Nesson, and Sannish Anticlines formed local highs where porous reservoirs formed in algal and bioclastic carbonate rocks. Porosity also was produced by secondary dolomitization. All of these anticlines have multiple producing zones. 
Several oil fields developed in Mississippian bioclastic and algal pellet banks are localized along the Brockton-Froid (Weldon) line of weakness (Hansen, 1966), and a future high level of drilling activity (fig. 13) may be expected in the northwest corner of the North Dakota lignite fields area. Many small oil fields with $15-30 \mathrm{~m}$ (50-100 ft) of closure produce from dolomites in the Ordovician Red River Formation. Whether these structures are tectonic or algal mounds is not known. Generally the structures die out in the overlying lower Paleozoic beds and consequently these structures are being located by the use of seismic Isopachs of lower Paleozoic intervals to find local paleothins above the Red River Formation. This approach has resulted in a fairly high rate of discovery of small ordovician oil pools. Because of this success, seismic activity probably will continue in parts of the lignite field (Fig. 13). 
Present production.--There are no individual fields in North Dakota in the glant size category; table 15 shows cumulative oil production for the twelve largest fields in North Dakota located on figure 13.

Table 15.--NEAR HERE

North Dakota is primarily an oil province and nearly all of this oil comes from Paleozoic carbonate reservoir rocks. Only a small amount is produced from Jurassic clastic rocks (Newburg field). These oil flelds also produce dissolved flammable gas. Gas is produced from the Cretaceous Eagle Sandstone in several small fields on the southeast end of the Cedar Creek Anticline, in southwest North Dakota, but these gas fields are generally outside the lignite field. Some non-flammable gas is present in the Pennsylvanian and Permian Minnelusa Formation on the Nesson Anticline. Figure 15 is a stratigraphic column modified from Sandberg (1962, fig. 5) that shows nomenclature, dominant

Figure 15.--NEAR HERE

lithology, and producing formations for the North Dakota part of the Williston Basin. According to Ashmore (1971, p. 693), about 92 percent of North Dakota's recoverable oil is in carbonate rocks and 74 percent of the total oil has been found in carbonate reservoirs of Mississippian age (Ashmore, 1971, table 1). 
Table 15.--Summary of selected North Dakota oil fields.

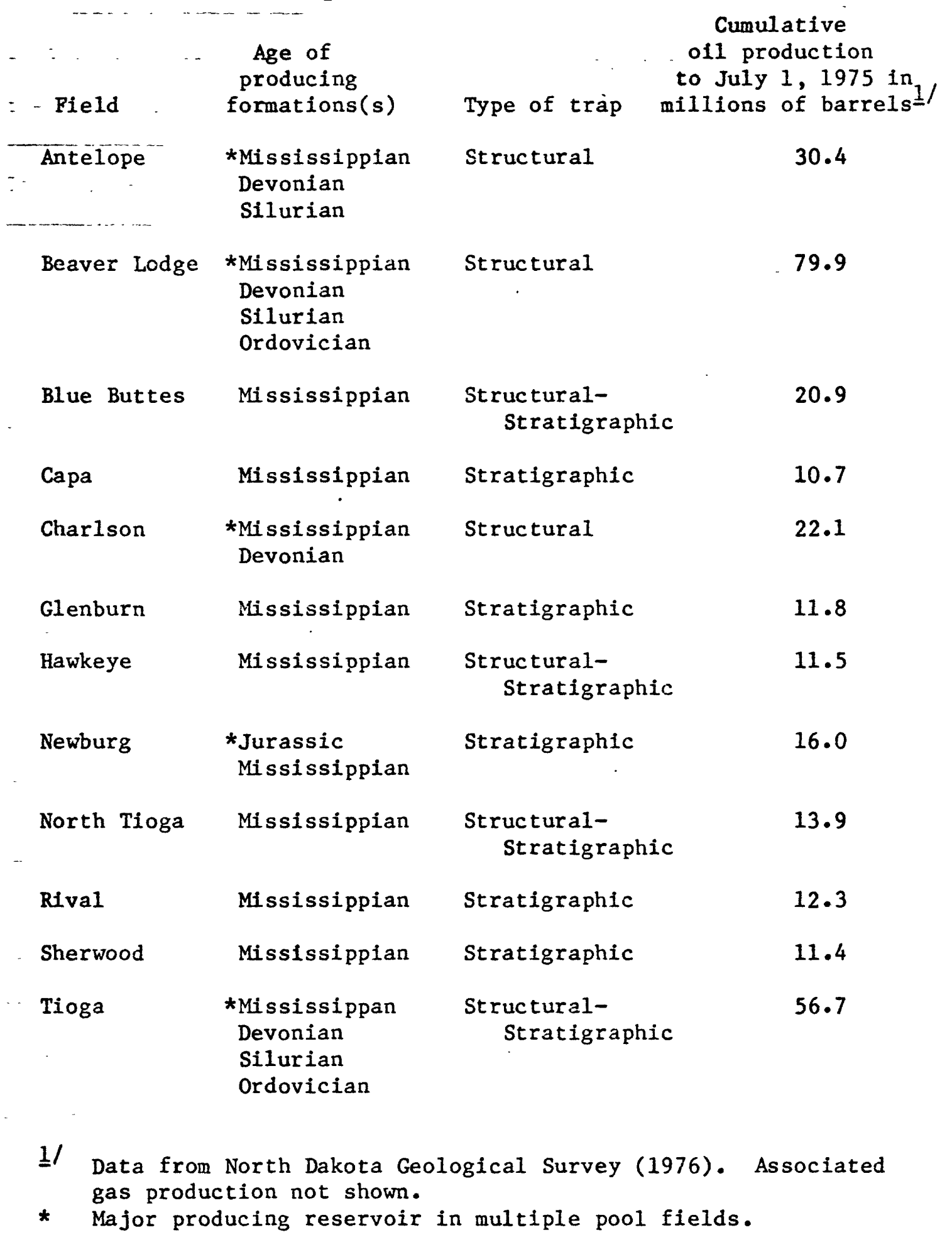




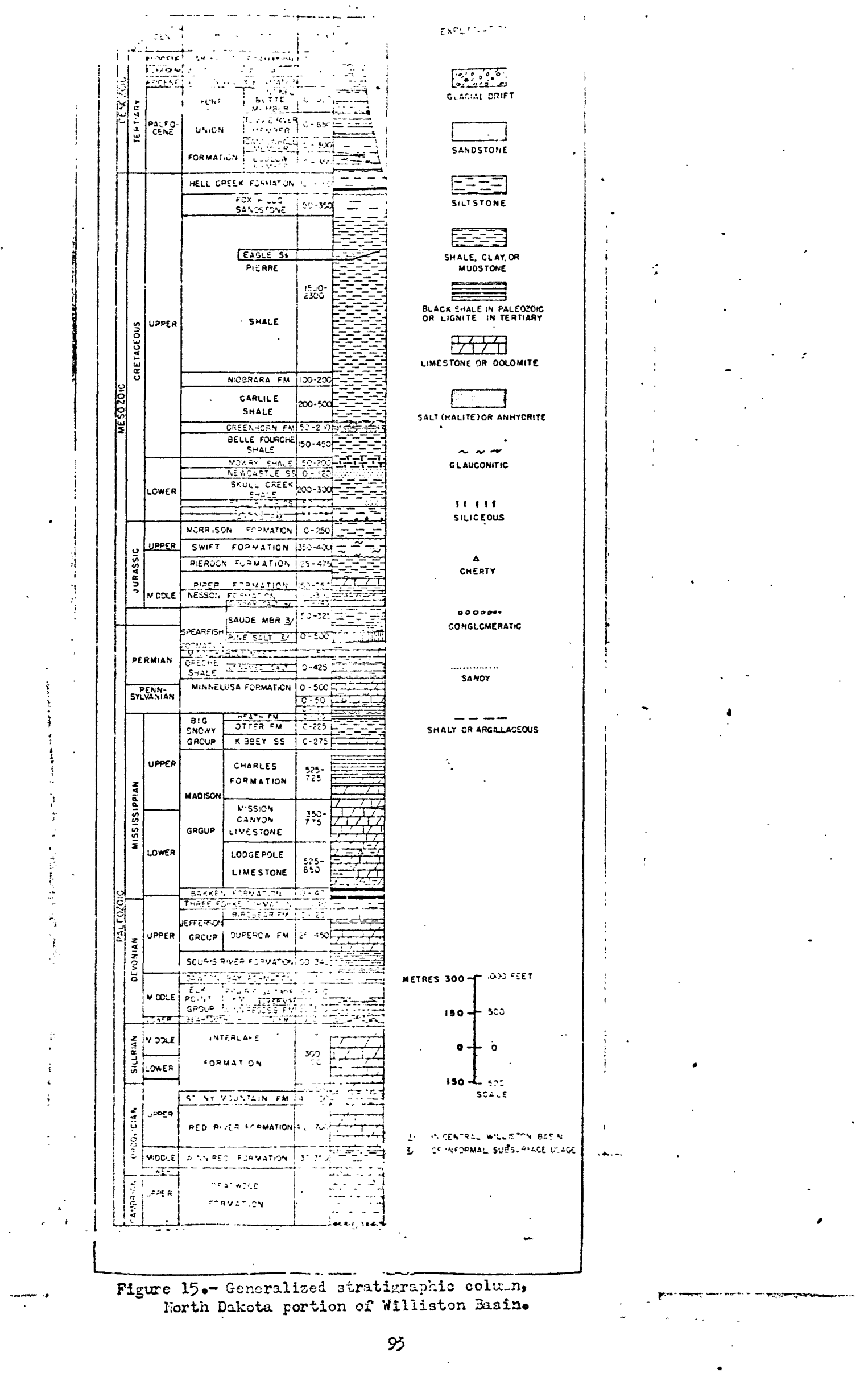


Future exploration.--Future exploration will involve detailed seismic mapping to define small, low-relief structural closures on lower Paleozoic reservoirs. This work may result in the drilling of large numbers of seismic shotholes $15-61 \mathrm{~m}(50-200 \mathrm{ft})$ deep. Logs of the shotholes might be valuable for lignite resource assessment. However, some modern seismic techniques, such as Vibroseis and Dynaseis, do not use shotholes.

The western half of North Dakota will continue to be a focal point of petroleum exploration. Recent research by Rice (1975) on the occurrence of shallow biogenic (methane) gas may spur considerable shallow drilling for dry gas in Tertiary and Cretaceous sandstones over the entire state. 


\section{Uranium resources}

by

Norman M. Denson

Uranium in North Dakota is largely restricted to the southwestern part of the State where it occurs in lignite and related carbonaceous materials. The carbonaceous host rocks containing the higher grade occurrences range from 0.15 to $0.6 \mathrm{~m}$ ( $6 \mathrm{in}$. to $2 \mathrm{ft}$ ) or more in thickness and are characterized by lenticularity, high ash contents (35-40 percent), and low heating values. The principal host rocks are nearly flat lying, and in general the stratigraphically and topographically higher carbonaceous beds in the mineralized sequence contain the most uranium. Most of the uranium-bearing host rocks in southwestern North Dakota are of early Tertiary (Paleocene) age and range from zero to about $365 \mathrm{~m}(1,200 \mathrm{ft})$ in thickness. Field relations indicate that the uranium is of secondary origin and was introduced long after the accumulation and marked regional uplift and warping of the lignite beds and associated rocks. Transportation and deposition of the uranium into the lignite is thought to have been by ground water moving downward and laterally from an overlying tuffaceous (volcanic) source rock. 
The two princlpal areas containing uraniferous lignite in southwestern North Dakota are (1) the Little Missouri River Escarpment area in west-central Billings County and the northwestern part of Stark County, and (2) the Chalky Buttes area in the south-central part of Slope County. The Little Missouri Escarpment area covers about 780 sq $\mathrm{km}$ (300 sq $\mathrm{mi}$ ) of gently rolling upland and about $260 \mathrm{sq} \mathrm{km}$ (100 sq $\mathrm{mi}$ ) of rugged badland terrain, whereas the Chalky Buttes area comprises about $39 \mathrm{sq} \mathrm{km}$ (15 sq $\mathrm{mi}$ ) of steep slopes flanking the prominent buttes. Minor local occurrences of uraniferous lignite underlie Sentinel and Flat Top Buttes in south-central Golden Valley County, Bullion Butte in southwestern Billings County, and the Medicine Pole Hills in western Bowman County. The uranium content of the lignite in these low-grade occurrences is not uniform but ranges from about 0.005 to 0.02 percent. Here the uranium is inconspicuously disseminated in the carbonaceous material and individual uranium minerals have not been identified. 
Many of the uranium occurrences in the Little Missouri River Escarpment area contain 0.1 percent or more uranium and are overlain at many localities by relatively thin overburden which make them amenable to strip mining. Uranium Magazine (1958, p. 13 and 26) reports that in the western Dakotas about 900,000 tons of proved reserves have been established, about half of which are in the Little Missouri River Escarpment area.

From 1962 to 1967, uraniferous lignite in southwestern North Dakota was burned in kilns or pits and the ash shipped to mills in South Dakota, Colorado, and New Mexico, where it was blended and treated along with sandstone ores. Both the burning and mining have now been discontinued, apparently because market demand could be more profitably satisfied elsewhere. 


\section{Construction materials}

by

Robert M. Lindvali

$=$ Construction materials in the Williston Basin portion of North Dakota are limited chiefly to sand and gravel, although very minor amounts of crushed stone, scoria, pseudoquartzites, and glacial boulders have been produced in the state in past years.

Sand and gravel.--In North Dakota, sand and gravel production is the third largest mineral industry, surpassed only by petroleum and coal in dollar value. In 1973, $\$ 6,021,000$ worth of sand and gravel was produced (Huvos, 1976). The sand and gravel is used mainly for concrete aggregate in paving and building construction, and for pit-run road metal. Minor uses include railroad ballast and fill material in construction work.

Sand and gravel deposits are widespread north and east of the Missouri River in the Williston Basin and are chiefly of glacial origin. The deposits include outwash plains, kames, kame terraces, eskers, deltas, and beaches. Most of these deposits are relatively small, and commonly are characterized by abrupt changes in quality and quantity. They may contain considerable amounts of clay and silt, and, though they provide material for local use, most are not of high commercial grade. 
Deposits south and west of the Missouri River are less widespread, and consist chiefly of terraces and point bar deposits along the major and some of the minor streams. The quality and quantity of these waterdeposited materials varies considerably and abrupt vertical changes in texture and sorting are common.

Information regarding the sand and gravel resources c.f the Williston Basin portion of North Dakota are available from maps, reports, and unpublished data from the U.S. Geological Survey, the North Dakota Geological Survey, the North Dakota State Water Commission, and the North Dakota State Highway Department. Geologic maps prepared in connection with county ground-water studies show the areal distribution of known surface deposits of sand and gravel. Maps and data from the subsurface exploration conducted for these studies are published by the North Dakota Geological Survey in their Bulletin Series, and by the North Dakota State Water Commission in the County Ground Water Study Series. Sizeable amounts of exploratory information as well as detailed analytical data on known sand and gravel deposits is available in the files of the North Dakota State Highway Department.

Stone.--Stone production in the Williston Basin area consists cheiefly of what is known commercially as "crushed and broken stone." Sources of this material include the "pseudoquartzites" and "scoria" of the area south and west of the Missouri River, and boulders from the glaciated areas. 
Pseudoquartzites.--"Pseudoquartzites" occur in many areas of the southern part of the Williston Basin. These rocks are composed of siliceous siltstones and mudstones and are very hard and resistant to weathering. Present commercial use seems to be limited to rip-rap material for facing earth dams.

Scoria.--Baked clay or natural bricklike material is included in the category of "crushed and broken stone." Locally, it is called "scoria" or "clinker," but probably more correctly should be called porcellanite. "Scoria" was formed when clay and shale beds overlying lignite were baked and fused by the heat of burning coal. The resulting pink, red, and blue-black deposits are widespread over the nonglaciated portion of the Williston Basin. Scoria is used widely as road metal in areas where sand and gravel are lacking. Other uses include driveways, walkways, and decorative lawn material.

Boulders.--Boulders, occurring in glacial materials, chiefly in areas north and east of the Missouri River, have been used for rip-rap, and to some extent as decorative stone in construction. 
Dimension stone.--The term "dimension stone" is applied to blocks or slabs of natural stone that are cut to definite shapes and sizes, used for building stone, walls and foundations, sidewalks, and memorials and other decorative areas. A sandstone bed in the Fort Union Formation in northwestern Billings County has been quarried for use chiefly as decorative stone in fireplaces, interior walls, barbeque pits, and patio flooring. 
Other nonmetallic mineral resources

by

Robert M. Lindvall

Nonmetallic mineral resources of the Williston Basin area include clay, salt, sodium sulfate, and sulfur.

Clay.-Clay deposits botil in bedrock and surficial materials are widespread in the Williston Basin area, but only those in the Golden Valley Formation (Paleocene and Eocene) are used commercially at present. Two plants manufacturing clay products were in operation in 1973 in Morton County, one producing face brick, the other lightweight aggregate.

Salt.--Salt is mined by solution methods at a depth of $2,440 \mathrm{~m}$ $(8,000 \mathrm{ft})$ from the Charles Formation (Mississippian) at Williston in Williams County by the Hardy Salt Company. Fresh water is injected into the salt bed and the recovered brine solution is evaporated in vacuum pans. Part of the salt is pressed into blocks for. use by ranchers and stockmen in cattle raising operations.

Sodium sulfate.--Sodium sulfate present in saline lakes or former lake basins that occupy undrained depressions in glacial deposits north and east of the Missouri River in the Williston Basin area. Limited development of these deposits was undertaken in 1937 and again in 1948, but little if any production has ever been recorded.

Sulfur.--Elemental sulfur is recovered as a byproduct of natural gas processing plants at Lignite in Burke County, and at Tioga in Williams County. 
Anderson, S. B., 1974, Pre-Mesozoic paleogeologic map of North Dakota: North Dakota Geol. Survey, Misc. Map 17. Andrews, D. A., 1939, Geology and coal resources of the Minot region, North Dakota: U.S. Geol. Survey Bull. 906-B, 84 p. Ashmore, H. T., 1971, Petroleum potential of North Dakota, in Cram, I. H., ed., Future petroleum provinces of the United States--Their geology and potential: Am. Assoc. Petroleum Geologists Memoir 15, v. 1, p. $692-705$.

Barclay, C. S. V., 1973, Geologic map and lignite deposits of the Glen Ullin quadrangle, Morton County, North Dakota: U.S. Geol. Survey Coal Inv. Map C-54. , 1974, Geologic map and lignite deposits of the Dengate quadrangle, Morton County, North Lakota: U.S. Geol. Survey Coal Inv. Map C-67.

Baria, D. N., 1975, A survey of trace elements in North Dakota and effulent streams from combustion and gasification facilities: Engineering Experiment Station, Univ. of North Dakota, 1975-1, 64 p.

Benson, W. E., 1953, Geology of the Knife River area, North Dakota: U.S. Geol. Survey open-file rept., $323 \mathrm{p}$. Bluemle, J. P., 1972, Pleistocene drainage development in North Dakota: Geol. Soc. America Bull., v. 83, no. 7, p. 2189-2193. , 1977, Geologic highway map of North Dakota: No. Dak. Geol. Survey Ed. Series 11, Misc. Map 19. 
Brant, R. A., 1953, Lignite resources of North Dakota: U.S. Geol. Survey Circ. 226, 78 p.

Brown, R. W., 1948, Correlation of Sentinel Butte shale in western North Dakota: American Association of Petroleum Geologists Bulletin

v. 32, p. 1265-1274.

- 1962, Paleocene floras of the Rocky Mountains and Great Plains:

U.S. Geol. Survey Prof. Paper 375, 119 p., 69 pls.

Cannon, H. L., and Hopps, H. C., 1971, editors, Environmental

geochemistry in health and disease: Geol. Soc. America Memoir 123, 230 p.

Carlson, C. G., compiler, 1969, Bedrock geologic map of North Dakota:

N. Dak. Geol. Survey Misc. Map 10.

, 1973, Geology of Mercer and Oliver Counties, North Dakota: No.

Dak. Geol. Survey Bull. 56.

Carlson, C. G., and Anderson, S. B., 1965, Sedimentary and tectonic

history of North Dakota part of Williston Basin: Bull. Am. Assoc.

Petroleum Geologists, v. 49, no. 11, p. 1833-1846.

, 1973a, Mineral and water resources of North Dakota--stratigraphy:

in Report for the Committee on Interior and Insular Affairs, United

States Senate, Part I, p. 31-41.

, 1973b, Mineral and water resources of North Dakota--structure:

in Report for the Committee on Interior and Insular Affairs, United

States Senate, Part I, p. 43-44. 
Carlson, C. G., Bakken, W. E., and Kume, Jack, 1960, Subsurface geology and development of petroleum in North Dakota: North Dakota Geol. $\therefore$ Survey Bull. 34, p. 124-143 (repr. from Compass, v. 37, no. 2, p. 123-143, 1960).

Collier, A. J., 1919, The Nesson Anticline, Williams County, North Dakota: U.S. Geol. Survey Bul1. 691, Part II, p. 211-217. Colton, R. B., Lemke, R. W., and Lindva11, R. M., 1963, Preliminary glacial map of North Dakota: U.S. Geol. Survey Misc. Geol. Inv. Map I-331.

Connor, J. J., Keith, J. R., and Anderson, B. M., 1976, Trace-metal variation in scils and sagebrush in the Powder River Basin, Wyoming and Montana: Jour. Research U.S. Geol. Survey, v. 4, p. 49-59. Denson, N. M., and Gill, J. R., 1965, Uranium-bearing lignite and carbonaceous shale in the southwestern part of the Williston Basin--a regional study: U.S. Geol. Survey Prof. Paper 463, 75 p. Dobbin, C. E., and Larsen, R. M., 1936, Geologic and structure-contour map of the Cedar Creek Anticline, Dawson Prairle, and Wibaux .... Counties, Montana, and Bowman County, North Dakota: U.S. Geol. Survey Map, $1: 63,360,2$ sheets.

Fahy, M. P., and Smith, W. K., 1976, Geotechnical properties of some ..... upper Fort Union rocks from the Decker area, Big Horn County, Montana: U.S. Geol. Survey Open-file Rept. 76-596, 110 p. Fieldner, A. C., and others, 1942, Typical analyses of coals of the U.S.: U.S. Bur. of Mines Bull. 446, 45 pages. Quoted by E. R. Landis in Mineral and Water Resources of North Dakota, N. D. Geol. Survey Bul1. $63^{\circ}, 252$ p. 
Hansen, A. R., 1966, Reef trends of Mississippian Ratcliffe zone, northeast Montana and northwest North Dakota: Am. Assoc. Petroleum Geologists Bul1., v. 50, no. 10, p. 2260-2268.

Hares, C. J., 1928, Geology and lignite resources of the Marmarth field, southwestern North Dakota: U.S. Geol. Survey Bull. 775, 110 p.

Hatch, J. R., and Swanson, V. E., 1976, Trace elements in Rocky Mountain coals: Proceedings, Symposium on the Geology of Rocky Mountain coal.

Hickey, L. J., 1969, Stratigraphy of the Golden Valiey Formation of western North Dakota [abs.]: Geol. Soc. America Abs. with programs for November, 1969 , p. 100 . , 1977, Stratigraphy and paleobotany of the Golden Valley Formation (Early Tertiary) of western North Dakota: Geol. Soc. America Mem. $150,181 \mathrm{p} \cdot, 55 \mathrm{pl}$

Hopps, H. C., and Cannon, H. L., 1972, editors, Geochemical environment in relation to health and disease: Annals of the New York Academy of Science, v. 199, 352 p.

Huvos, J. B., 1976, The mineral industry in North Dakota: U.S. Bur. Mines Minerals Yearbook, 1973, v. 2, Area Reports--Domestic. Johnson, W. D., Jr., and Kunkel, R. P., 1959, The Square Buttes Coal Field, 0liver and Mercer Counties, North Dakota: U.S. Geol. Survey Bul1. 1076, 91 p.

Keefer, W. R., 1974, Regional topography, physiography, and geology of the northern Great Plains: U.S. Geol. Survey Open-file Rept. $74-50,18 \mathrm{p}$. 
Klein, D. H., Anders, W. A., and Boiton, N. E., 1975, Trace element discharges from coal combustion for power production. Water, Air, and Soil Pollution, ser. 5, p. 71-77: Dordrecht, Holland,

D. Reider Pub. Co.

Landis, E. R., 1973, Mineral and water resources of North Dakota, economic geology, mineral fuel resources--coal: in Report for the Committee on Interior and Insular Affairs, United States Senate, part I, p. 45-52.

Lemke, R. W., 1953, Geology of the Velva quadrangle, North Dakota: U.S. Geol. Survey Geol. Quad. Map GQ-31. , 1960, Geology of the Souris River area, North Dakota: U.S. Geol. Survey Prof. Paper 325, 138 p.

Lemke, R. W., Laird, W. M., Tipton, M. J., and Lindval1, R. M., 1965, Quaternary geology of Northern Great Plains: in The Quaternary of the United States--A review volume for the VII Congress of the Int. Assoc. for Quat. Research, H. E. Wright, Jr.,. and David G. Frey, eds.: Princeton University Press, Princeton, New Jersey, p. 15-27. Metzger, Charles, 1976, Governor Link's Energy Advisor quoted in Energy Era, May 29, 1976, v. 3, no. 3, p. $2 f$ and charts. Moore, G. W., Melin, R. E., and Kepferle, R. C., 1956, Preliminary geologic map of the Chalky Buttes area, Slope County, North Dakota: U.S. Geol. Survey Coal Inv. Map C-38.

Nevin, C. M., 1946, The Keene dome, northeast McKenzie County, North Dakota: N. Dak. Geol. Survey Bull. 21, p. 1-10.

North Dakota Geological Survey, 1976, 0il and gas production statistics, first half of 1975: Grand Forks, North Dakota, 274 p. 
Northern Great Plains Resource Program, 1975.

0'Gorman, J. V., and Walker, P. L., 1972, Mineral matter and trace elements in U.S. Coals: Office of Coal Research, U.S. Dept. of Interior, Research and Development Rept. No. 2, 183 p. (G.P.O. Catalog No. 163.10:61/Int. 2).

Pollard, B. C., Smith, J. B., and Knox, C. C., 1972, Strippable coal resources of North Dakota: U.S. Bur. of Mines Info. Circ. 8537, $37 \mathrm{p}$.

Radian Corporation Staff, 1975, Coal fired power plant trace element study: prepared for Environmental Protection Agency, vols. I and II, station III.

Rehbein, E. A., 1977, Preliminary report on stratigraphy and depositional environments of the lignites in the Fort Union Formation, west-central North Dakota: U.S. Geol. Survey Open-file Rept. 77-69, $23 \mathrm{p}$.

Rice, D. D., 1975, Origin of and conditions for shallow accumulations of natural gas, in Geology and mineral resources of the Bighorn Basin: Wyoming Geol. Assoc. Guidebook 27th Ann. Field Conf., p. 267-271. Roe, W. B., 1950, Geological features of North Dakota 1ignites: Econ. Geology, v. 45, p. 434-440.

Royse, C. F., Jr., 1967, Tongue River--Sentinel Butte contact in western North Dakota: N. Dak. Geo1. Survey Rept. Inv. 45, 53 p.

Sandberg, C. A., 1962, Geology of the Williston basin, North Dakota, Montana, and South Dakota, with reference to subsurface disposal of radioactive wastes: U.S. Geol. Survey Trace Elements Inv. Rept., TEI-809, $148 \mathrm{p}$. 
Sawatzky, H. B., 1975, Astroblemes in Williston Basin: Am. Assoc. Petroleum Geologists Bull., v. 59, no. 4, p. 694-710.

Shacklette, H. T., Erdman, J. A., Harms, T. F., and Papp, C. S. E., 1976, Trace elements in plant foodstuffs in Oehme, F. W., ed., Toxicity of Heavy Metals in the Environment: Marcel Dekker, New York (in press).

Smith, H. L., 1973, Geologic map and lignite deposits of the New Salem quadrangle, Morton County, North Dakota: U.S. Geol. Survey Coal Inv. Map C-62.

Smith, J. B., Pollard, B. C., and Knox, C. C., 1973, Mineral and water resources of North Dakota, strippable lignite reserves: in Report for the Committee on Interior and Insular Affairs, United States Senate, p. 52-57.

Soward, K. S., 1975a, Geologic map and coal resources of the White Butte West quadrangle, Hettinger County, North Dakota: U.S. Geol. Survey Coal Inv. Map C-69. , 1975b, Geologic map and coal resources of the White Butte East quadrangle, Hettinger County, North Dakota: U.S. Geol. Survey Coal Inv. Map $\mathrm{C}-70$. , 1975c, Geologic map and coal resources of the White Butte NW quadrangle, Stark and Hettinger Counties, North Dakota: U.S. Geol. Survey Coal Inv. Map C-71. , 1975d, Geologic map and coal resources of the White Butte NE quadrangle, Stark and Hettinger Counties, North Dakota: U.S. Geol. Survey Coal Inv. Map C-72. 
Stephens, E. V., 1970a, Geologic map of the Heart Butte NW quadrangle, Morton and Grant Counties, North Dakota: U.S. Geol. Survey Coal Inv. Map C-52.

, 1970b, Geologic map of the Heart Butte quadrangle, Morton and Grant Counties, North Dakota: U.S. Geol. Survey Coal Inv. Map C-53.

Stone, D. S., 1970, Principal horizontal stress in the central Rocky Mountains versus California: The Mountain Geologist, v. 7, no. 2, p. 69-82.

Symposium Proceedings sponsored by ERDA and Univ. of North Dakota 1975, Technology and use of lignite, GFERC/1c-75/2, $371 \mathrm{p}$. Thomas, G. E., 1974, Lineament-block tectonics: Williston-Blood Creek Basin: Am. Assoc. Petroleum Geologists Bull., v. 58, no. 7, p. $1305-1322$.

Uranium Magazine, 1958.

U.S. Environmental Protection Agency, 1975a, Interim primary drinking water regulations: 40 Code of Federal Regulations, Pt. 141, Federal Register, v. 40, no. 51, March 14, 1975, p. 11,990-11,998. - 1975b, Interim primary drinking water regulations: 40 Code of Federal Regulations, Pt. 141, Federal Register, v. 40, no. 150, August 14, 1975,5 p.

U.S. Geological Survey, 1974a, Stripping coal deposits of the northern Great Plains, Montana, Wyoming, North Dakota, and South Dakota: U.S. Geological Survey Miscellaneous Field Studies Map MF-590. 
U.S. Geological Survey, 1974b, Geochemical survey of the Western Coal Regions, 1st ann. progress report (July, 1974): U.S. Geol. Survey Open-file Rept. 74-250, 38 p.

, 1975, Geochemical survey of the Western Coal Regions, 2nd ann. progress report (July, 1975): U.S. Geol. Survey Open-file Rept. $75-436,132 \mathrm{p}$.

, 1976a, Geochemical survey of the Western Energy Regions (formerly Geochemical survey of the Western Coal Regions), 3rd ann. progress report, July, 1976: U.S. Geol. Survey Open-file Rept. 76-729. , 1976b, Minor and trace elements in coal--a selected bibliogrpahy of reports in English: U.S. Geol. Survey Open-File Rept. 76-481, 29 p. , 1977, Geochemical survey of the Western Energy Regions, 4th ann. progress report, July 1977: U.S. Geol. Survey Open-file Rept. $\therefore \quad$ 77-872, $207 \mathrm{p}$.

U.S. Geological Survey and the Am. Assoc. Petroleum Geologist, 1961, Tectonic map of the United States.

von Hake, C. A., 1975, Earthquake history of North Dakota: Earthquake Info. Bull., v. 7, no. 6, p. 22-23.

Zeiglar, D. L., 1955, Pre-Piper Post-Minnekahta "Red Beds" in the Williston Basin: North Dakota Geol. Soc. Guidebook, Black Hills Field Conf. 